\title{
COVID-19 Salgını ve Bulaşıcı Hastalıkların Yarattı̆ı Küresel Krizlerle Mücadelede Uluslararası Hukuk
}

\author{
Cüneyt Yüksel ${ }^{*}\left(\mathbb{D}\right.$, Deniz Baran** ${ }^{*}$
}

Öz

2019'un sonlarında ortaya çıkan COVID-19 salgını tüm dünyayı sarsmaya devam etmektedir. Salgın bu zamana kadar yaşanan can kayıplarının yanı sıra sağlık, ekonomi, ticaret ve seyahat gibi birçok alanda son yüzyılın belki de en sarsıcı tahribatlarından birine sebep olmuştur. Salgının büyük bir hızla yayılışı, başta Dünya Sağıık Örgütü (DSÖ) olmak üzere küresel ölçekte etkili bir işbirliği ve koordinasyon sağlaması beklenen mekanizmaların rollerini gündeme getirmiştir. Bu makalenin amacı, uluslararası hukukta COVID-19 salgını ve bulaşııı hastalıkların yarattğı küresel krizlerle mücadele yönetimine ilişkin kurumsal mekanizmaların ve düzenlemelerin değerlendirilmesidir. Illk bölümde DSÖ’nün yapısı ve düzenlemeleri ortaya konulmakta, özellikle 2005 tarihli Uluslararası Sağlık Tüzüğü’nün hükümleri detaylı bir şekilde incelenmektedir. İkinci bölümde DSÖ sisteminin COVID-19 salgını bağlamında nasıl bir işlev gösterdiği değerlendirilmekte ve mevcut eksikliklere yönelik çözüm önerileri sunulmaktadır. Son bölümde ise uluslararası sağlık hukukunun dışında kalan fakat COVID-19 salgını ve bulaşııı hastalıkların sebep olduğu küresel krizler ile doğrudan bağlantlı olan uluslararası insan hakları hukuku, uluslararası ticaret hukuku ve uluslararası kolektif güvenlik sistemi alanlarındaki küresel yönetim mekanizmalarının oynadığı roller incelenmektedir. Tüm bu değerlendirmelerin neticesinde salgınlar gibi küresel sorunların etkili çözümünde uluslararası hukukun sahip olduğu kritik önem vurgulanmaktadır.

\section{Anahtar Kelimeler \\ COVID-19 salgını ve uluslararası hukuk, Dünya sağlık örgütü (DSÖ), 2005 tarihli uluslararası sağlık tüzüğü (UST), Uluslararası sağlık hukuku ve küresel yönetim}

International Law in Combatting the Global Crises Caused By the COVID-19 Pandemic and Infectious Diseases

\begin{abstract}
The COVID-19 pandemic, which emerged in late 2019, continues to unsettle the entire world. Along with the losses of many lives, the pandemic caused maybe one of the most devastating damage in the last century on many fields such as healthcare, economy, trade, and tourism. The rapid contagion of the pandemic has brought into question the roles of the international institutions, primarily the World Health Organization (WHO), which are expected to build a ground for the global cooperation and coordination. The purpose of this article is to provide an assessment of the institutional mechanisms and instruments in international law for combatting the global crises caused by the COVID-19 pandemic and infectious diseases. In the first chapter, WHO's structure and regulations are explained, and particularly the International Health Regulations (2005) are examined in detail. In the second chapter, the functionality of the WHO system during the COVID-19 pandemic is evaluated, and some solutions for the current deficiencies of the system are proposed. In the final chapter, the direct relation between the global crises caused by the COVID-19 pandemic and infectious diseases and the roles played by global governance systems in the fields of international human rights law, international trade
\end{abstract}

* Sorumlu Yazar: Cüneyt Yüksel (Prof. Dr.), İstanbul Üniversitesi, Hukuk Fakültesi, Milletlerarası Hukuk Anabilim Dalı, İstanbul, Türkiye. E-posta: cuneyt.yuksel@istanbul.edu.tr ORCID: 0000-0001-8580-6967

** Deniz Baran (Araş. Gör.), İstanbul Üniversitesi, Hukuk Fakültesi, Milletlerarası Hukuk Anabilim Dalı, İstanbul, Türkiye. E-posta: denizbaran@istanbul.edu.tr ORCID: 0000-0002-9761-1910

Attf: Yuksel C, Baran D, “COVID-19 Salgını ve Bulaşıcı Hastalıkların Yarattğı Küresel Krizlerle Mücadelede Uluslararası Hukuk” (2020) 78(2) İstanbul Hukuk Mecmuası 885. https://doi.org/10.26650/mecmua.2020.78.2.0020 
law, and international collective security system are examined. In conclusion of this article, the significance of international law for effectively solving global problems such as pandemics is emphasized.

\section{Keywords}

COVID-19 pandemic and international law, World health organization (WHO), International health regulations (2005) (IHR), International health law and global governance

\section{Extended Summary}

The COVID-19 pandemic, which emerged in late 2019, continues to unsettle the entire world. Along with the losses of many lives, the pandemic caused maybe one of the most devastating damage in the last century on many fields such as healthcare, economy, trade, and tourism. Even though handling such a crisis requires intensive cooperation on a global scale, many states have been resorted to more isolation and solely national solutions. Therefore, the trajectory of globalisation as well as concepts such as multilateral international systems and international cooperation became questionable. Hence, the rapid contagion of the pandemic has inevitably brought into question the roles of international institutions, primarily the World Health Organization (WHO) but also the United Nations (UN), the World Trade Organization (WTO), and the European Union (EU), which are expected to build global cooperation and coordination.

The purpose of this article is to provide an assessment of the institutional mechanisms and instruments in international law for combatting the global crises caused by the COVID-19 pandemic and infectious diseases. In the first chapter, WHO's structure and regulations are explained, and the International Health Regulations (2005) (IHR) are examined in detail. The main purpose of WHO is to become a global public health authority which could develop international health norms and coordinate international cooperation on health matters. The WHO Constitution clearly states that it aims the highest attainable health level for all people. The establishment of WHO is the clear demonstration of the strong and collective will of the international community in order to improve the level of the global public health after the Second World War. This is why the member states granted significant normative authorities, which most other international organizations do not possess, to WHO. However, once it became clear in the 21 st century that the IHR of WHO was not addressing the realities on the ground anymore and was insufficient for the struggles against pandemics, a new version of IHR was adopted in 2005. This new version brought about great changes in the rules of the international health law, and the system was improved. The SARS (Severe Acute Respiratory Syndrome) pandemic was the main accelerator of the abovementioned changes, and now the IHR (2005) regime is subject to a serious scrutiny during the COVID-19 pandemic. 
In the second chapter, the functionality of the WHO system during the COVID-19 pandemic is evaluated, and some solutions for the current deficiencies of the system such as the insufficient framework for the development of the national public health surveillance capacities or the lack of a mechanism to enforce the implementation of the rules are proposed. However, the combat with the pandemic has also once again proven that current global health governance and implementation of the rules are highly dependent on the behavior of states. Therefore, it is accurate to argue that most of the deficiencies of the current system are directly related to the non-compliance of states with IHR norms, even though WHO itself has some shortcomings in general.

In the final chapter, the direct relation between the global crises caused by the COVID-19 pandemic and infectious diseases and the roles played by global governance system in the fields of international human rights law, international trade law and international collective security system are examined. In the context of international human rights law, the matters of the right to health, derogation, the confidentiality of personal information and surveillance technologies are discussed. Furthermore, in the context of international trade law, the article focuses on the exceptions stipulated by the General Agreement on Tariffs and Trade (GATT) and other WTO agreements regarding trade measures and the matter of intellectual property in the medical field. Last but not least, in the context of international collective security system, the first and foremost issue is the role of the UN Security Council in combatting against pandemics, particularly, the Security Council's previous responses to the other pandemics are examined in comprasion with its response to the COVID-19 pandemic.

In conclusion of this article, the significance of international law for effectively solving global problems such as pandemics is emphasized. Unfortunately, many factors including the tendency of many states to adopt solely national solutions during crisis moments such as pandemics, the rapid politicization of the global health matters in a way to sideline human rights concerns, the lack of capacity of many states to combat the pandemics, the insufficient level of global funds, the ideological disagreements on public health policies, all restrict the possibility of the creation of a ground for international solidarity and cooperation needed by the international community. The most important core global value which should facilitate the creation of this ground shall be international law due to international law having many critical roles to play for the resolution of global problems. The virus, having caused the current pandemic, is one of the "invisible enemies of humanity" just like global problems which do not recognize national borders such as but not limited to climate change, transboundary criminal organizations or terrorism. The main feature of such global problems is that they are irresolvable by any nation state alone regardless of its national wealth or power. This is why combatting global crises requires the coordination and cooperation of international law and why international law is our most significant global value system. 


\section{COVID-19 Salgını ve Bulaşıcı Hastalıkların Yarattığı Küresel Krizlerle Mücadelede Uluslararası Hukuk}

\section{Giriş}

2019'un sonlarında baş gösteren COVID-19 salgını' tüm dünyayı sarsmaya devam etmektedir. ${ }^{2}$ İlk olarak Çin'in Wuhan şehrindeki bir hayvan pazarından insanlara bulaştığı tahmin edilen bu hayvan kaynaklı (zoonotik) virüs ${ }^{3}$ bu zamana kadar dünya çapında yüz binlerce insanın ölümüne sebep olmuştur. Yaşanan can kayıplarının yanı sıra sağlık, ekonomi, ticaret ve seyahat gibi birçok alanda son yüzyılın belki de en sarsıcı tahribatlarından birine sebep olmuştur. Örneğin, küresel ticarette üçte bire yakın bir düşüş yaşanmıştır. ${ }^{4}$ Öyle ki 2008 yılında yaşanan küresel ekonomik krizden daha kötü bir kriz kaçınılmaz görülmektedir. ${ }^{5}$ COVID-19 salgınının tarihe Birinci ve İkinci Dünya Savaşları yahut 11 Eylül saldırısı gibi küresel ölçekte genel yaklaşımların değişimine sebep olacak bir kriz olarak geçeceğini iddia edenler dahi vardır. ${ }^{6}$ Devletler yakın tarihte emsali görülmemiş boyutta önlemleri devreye sokmuş, birçok devlet olağanüstü hâl veya acil durum ilân etmek durumunda kalmıştır. Dünya Bankas1 $^{7}$ ve Uluslararas1 Para Fonu (IMF) ${ }^{8}$ gibi uluslararas1 örgütler acil ekonomik yardım ve destek paketlerini ilân etmişlerdir. Böylesine büyük çaplı ve çok yönlü bir krizi beraberinde getiren COVID-19 salgınının sarsıcı etkisi sebebiyle birçok mahfilde küreselleşme çağının bitip bitmediği dahi tartışılacak seviyeye gelmiştir.9

\footnotetext{
Dünya Sağlık Örgütü salgın durumunu nitelemek üzere “pandemi” terimini kullanmaktadır. Biz bu terimin Türkçesi olan salgın kavramını kullanmayı tercih etmekteyiz. Dünya Sağlık Örgütü'ne göre bir durumun salgın (pandemi) olarak nitelenebilmesi için insanlar arasında kolayca bulaşabilen yeni bir hastalığın istikrarlı bir şekilde, dünyanın farklı noktalarında, kitleler üzerinde görülmeye başlaması gereklidir, bkz Dünya Sağlık Örgütü, 'What is a pandemic?' (WHO, 24 Şubat 2020)<https://www.who. int/csr/disease/swineflu/frequently_asked_questions/pandemic/en/> Erişim tarihi 15 Mayıs 2020.

2 Genel bilgi için bkz Dünya Sağlık Örgütü, 'Coronavirus Disease (COVID-19) Outbreak’ $(W H O)<$ https://www.who.int/ emergencies/diseases/novel-coronavirus-2019/events-as-they-happen> Erişim tarihi 15 Mayıs 2020.

3 Dünya Sağlık Örgütü, 'Report of the WHO-China Joint Mission on Coronavirus Disease 2019 (COVID-19)' (WHO) $<$ https:/www.who.int/docs/default-source/coronaviruse/who-china-joint-mission-on-covid-19-final-report.pdf> Erişim Tarihi 15 Mayis 2020.

4 'COVID-19 Triggers Marked Decline in Global Trade' (UNCTAD, 13 Mayıs 2020) < https://unctad.org/en/Pages/ PressRelease. aspx? OriginalVersionID=553> Erişim Tarihi 15 Mayıs 2020.

5 'Much of global commerce has ground to a halt' (The Economist, 21 Mart 2020) <https://www.economist.com/ business/2020/03/21/much-of-global-commerce-has-ground-to-a-halt> Erişim Tarihi 15 Mayıs 2020.

${ }_{6}$ Ufuk Ulutaş, 'Koronavirüs Sonrası Küresel Trendler' in T.C. Dışişleri Bakanlığı Stratejik Araştırmalar Merkezi (ed), COVID-19 Sonrası Küresel Sistem: Eski Sorunlar Yeni Trendler ( SAM Yayınları 2020) 10.

7 'World Bank Group President David Malpass Remarks to G20 Leaders' Virtual Summit' (WorldBank, 26 Mart 2020) $<$ http://documents.worldbank.org/curated/en/964171585579938056/pdf/Remarks-by-World-Bank-Group-PresidentDavid-Malpass-to-G20-Leaders-Virtual-Summit.pdf> Erişim Tarihi 15 Mayıs 2020.

8 'How the IMF Can Help Countries Address the Economic Impact of Coronavirus' < https://www.imf.org/en/About/ Factsheets/Sheets/2020/02/28/how-the-imf-can-help-countries-address-the-economic-impact-of-coronavirus> Erişim Tarihi 15 Mayis 2020.

9 'Has covid-19 killed globalisation?' (The Economist, 14 May1s 2020) <https://www.economist.com/leaders/2020/05/14/ has-covid-19-killed-globalisation?utm_source=dailybrief\&utm_medium=email\&utm_campaign=DailyBrief2020May $15 \&$ utm_term=DailyNewsBrief; > Erişim Tarihi 15 Mayıs 2020.
} 
Küreselleşme çağının akıbetine yönelik tartışmalarla birlikte küresel yönetim, ${ }^{10}$ uluslararası sistemde çok taraflılık ve işbirliği gibi kavramlar da sorgulanır hâle gelmiştir. ${ }^{11}$ Zira küresel çapta yoğun bir işbirliği gerektiren böylesine bir krizde, panik hâlindeki çoğu devletin içine kapanmasına ve salt ulusal ölçekli çözümleri öncelemelerine tanıklık edilmektedir. ${ }^{12}$ Bilhassa COVID-19 salgınının kaynağı konumundaki Çin'e ve uluslararası sağlık yönetiminin temel mercii olan Dünya Sağlık Örgütü’ne(DSÖ) karşı sert suçlamalar da görülmektedir. ${ }^{13}$ Gerçekten de Çin'in ve DSÖ'nün mevcut salgına ilişkin sorumluluklarının tartışılması kaçııılmaz bir meseledir. Zira salgının ilk ortaya çıktı̆̆ı dönemde Çin yetkililerinin aldıkları kararlarla COVID-19 salgınının tüm dünyayı saracak şekilde kontrolden çıkmasına sebep olduklarına ilişkin birçok bulgu vardır. ${ }^{14}$ Söz konusu hastalığın SARS (Severe Acute Respiratory Syndrome) benzeri tehlikeli bir koronavirüs olabileceğine dair bulguların ilk ortaya çıkışının Kasım 2019'a kadar gittiği bilinmesine rağmen ${ }^{15}$ Çin halkının o dönemde yaklaşan kameri yılbaşı bayramına yakın dönemde büyük kitleler hâlinde seyahat etmeleri engellenmemiş ${ }^{16}$ ve DSÖ’ye Çin tarafindan COVID-19 virüsüne ilişsin yapılan ilk bildirim 31 Aralık 2019' da gerçekleşmiştir. ${ }^{17}$

10 Küresel yönetim kavramı bizler için, ulusal sınırları aşan ve küresel toplumu ilgilendiren meselelerin, sadece devletler merkezli olmayıp farklı aktörlerin de katılım gösterdiği, daha az hiyerarşik ve daha az merkeziyetçi karar alma ve uygulama mekanizmaları ile yönetilmesini ifade etmektedir, Cüneyt Yüksel, Uluslararası Hukuk ve Ekonomik Kalkınma (Alfa 2020) 23.

11 Yuval Noah Harari, 'The World After Coronavirus' (Financial Times, 20 Mart 2020) <https://www.ft.com/content/19d903086858-11 ea-a3c9-1 fe6fedcca75> Erişim Tarihi 29 Mart 2020; Henry Kissinger, 'The Coronavirus Pandemic Will Forever Alter the World Order' (Wall Street Journal, 3 Nisan 2020) < https://www.wsj.com/articles/the-coronavirus-pandemic-will-foreveralter-the-world-order-11585953005> Erişim Tarihi 29 Nisan 2020; Anne-Marie Slaughter, 'Redefining National Security for the Post-Pandemic World' (Project Syndicate, 3 Haziran 2020), <https://www.project-syndicate.org/commentary/redefiningnational-security-for-world-after-covid19-by-anne-marie-slaughter-2020-06> Erişim Tarihi 16 Haziran 2020; Ian Buruma, 'The Virus of Fear' (Project Syndicate, 6 Mart 2020) <https://www.project-syndicate.org/commentary/coronavirus-fearincreases-violence-potential-by-ian-buruma-2020-03?barrier=accesspaylog $>$ Erişim Tarihi 16 Haziran 2020.

12 Örneğin, Avrupa Birliği'ne üye devletler ilk defa kendi ulusal sınırlarını tamamen birbirine kapatmıştır, bkz 'European Union: are borders the antidote to the Covid-19 pandemic?' (The Conversation, 17 Nisan 2020) <https://theconversation. com/european-union-are-borders-the-antidote-to-the-covid-19-pandemic-136643> Erişim Tarihi 16 Haziran 2020.

13 Matthew Anderson vd, 'Coronavirus Compensation? Assessing China's Potential Culpability and Avenues of Legal Response' (Henri Jackson Society, 5 Nisan 2020)<https://henryjacksonsociety.org/publications/coronaviruscompensation/> Erişim Tarihi 16 Haziran 2020, s 7-8.

14 James Kraska, 'China is Legally Responsible for COVID-19 Damage and Claims Could Be in the Trillions' (War on the Rocks, 23 Mart 2020) <https://warontherocks.com/2020/03/china-is-legally-responsible-for-covid-19-damage-andclaims-could-be-in-the-trillions/> Erişim Tarihi 16 Mayıs 2020; ibid 7-8; Helen Davidson, 'First Covid-19 case happened in November, China government records show - report' (The Guardian, 13 Mart 2020) < https://www.theguardian.com/ world/2020/mar/13/first-covid-19-case-happened-in-november-china-government-records-show-report> Erişim Tarihi 16 Mayıs 2020; 'C.D.C. and W.H.O. Offers to Help China Have Been Ignored for Weeks' (New York Times, 7 Şubat 2020) $<$ https://www.nytimes.com/2020/02/07/health/cdc-coronavirus-china.htmll Erişim Tarihi 17 Mayıs 2020.

15 Gerry Shih, Emily Rauhala ve Lena H Sun, 'Early missteps and state secrecy in China probably allowed the coronavirus to spread farther and faster' (Washington Post, 1 Şubat 2020) < https://www.washingtonpost.com/world/2020/02/01/earlymissteps-state-secrecy-china-likely-allowed-coronavirus-spread-farther-faster/> Erişim Tarihi 28 Şubat 2020; Talita de Souza Dias, Antonio Coco, 'Part III: Due Diligence and COVID-19: States' Duties to Prevent and Halt the Coronavirus Outbreak' (EJIL Talk, 25 Mart 2020) <ejiltalk.org/part-iii-due-diligence-and-covid-19-states-duties-to-prevent-and-halt-the-coronavirusoutbreak/> Erişim Tarihi 16 Mayıs 2020; Li Yuan, 'China Silences Critics Over Deadly Virus Outbreak' (New York Times, 22 Ocak 2020) https://www.nytimes.com/2020/01/22/health/virus-corona.html, Erişim Tarihi: 28 Şubat 2020.

1631 Aralık 2019'da Wuhan Yerel Halk Komisyonu, COVID-19'un insandan insana geçmediği yönünde son derece yanlış bilgilendirme yapan bir açıklamada bulunmuş, mevcut salgını mevsimsel bir grip olarak niteleyip durumun kontrol altında olduğunu belirtmişti. Muhtemelen Çin yönetiminin yayından kaldırmasından ötürü bağlantı artık çalışmıor olsa da bkz 'Wuhan Yerel Halk Komisyonu' (WJW, 31 Aralık 2019) <http://wjw.wuhan.gov.cn/front/web/showDetail/2019123108989> Erişim Tarihi 16 Mayıs 2020.

17 Ancak 14 Şubat 2020'ye kadar, Çinli sağlık çalışanlarının da yeni virüsten enfekte olduğunu içeren kapsamlı bir bilgilendirme yapılmamıștır, Emily Rauhala, 'World Health Organization: China not sharing data on coronavirus infections among health-care workers' (Washington Post, 26 Şubat 2020) <https://www.washingtonpost.com/world/asia_pacific/ world-health-organization-china-not-sharing-data-on-health-care-worker-coronavirus-infections/2020/02/26/28064fda54e4-11ea-80ce-37a8d4266c09_story.html> Erişim Tarihi 28 Şubat 2020. 
Öte yandan, genelde küresel yönetime, özelde ise uluslararası sağlık hukukuyla ilgili mekanizmalara dair süren tartışmalar sadece Çin veya DSÖ ile sınırlı değildir, adeta tüm uluslararası sistem sorgulanmaktadır. COVID-19 salgınının hızla yayılışı, küresel ölçekte etkili bir işbirliği ve koordinasyon sağlaması beklenen mekanizmaların rollerini gündeme getirmiştir. Örneğin, DSÖ ve DSÖ düzenlemeleri uluslararası gündemin üst sıradaki başlıklarından biri hâline gelmiştir. Ayrıca Birleşmiş Milletler (BM), Dünya Ticaret Örgütü (DTÖ) ve Avrupa Birliği (AB) gibi uluslararası örgütlerin işlevsellikleri tartışılmaya başlanmıştır. ${ }^{18}$ Günümüzde birçok hükümetin böylesi kriz anlarında ulusal bir yaklaşımı benimsemeye yatkın olması, küresel sağlı meselelerinin insani kaygıları ikinci plâna atabilecek bir hızla siyasileşmesi, çok sayıda devletin salgınla mücadele için gerekli kaynaklardan mahrum oluşu, küresel ölçekte finansman yetersizliği, kamusal sağlık politikaları hususundaki ideolojik ayrılıklar gibi birçok unsur uluslararası toplumun ihtiyaç duyduğu seviyede küresel bir dayanışma zemini oluşturmanın imkanını oldukça kısıtlamaktadır. ${ }^{19} \mathrm{Bu}$ zemini sağlayacak değer çok taraflı işbirliği ve uluslararası hukuk olmalıdır. Zira küresel sorunların çözümünde uluslararası hukukun oynayacağı son derece hayati roller mevcuttur. Söz konusu salgına yol açan virüs de tüm "insanlı̆̆ın görünmez düşmanlarından" ve aynı iklim değişikliği, sınır aşan suç şebekeleri veya terör faaliyetleri gibi ulusal sınırları hiçbir şekilde tanımayan küresel sorunlardan biri mahiyetindedir. ${ }^{20}$ Böylesi küresel sorunların temel özelliği, zenginliği ve gücü ne seviyede olursa olsun hiçbir devletin tek başına çözemeyeceği, dolayısıyla iyi bir küresel yönetimi ve uluslararası hukukun koordinasyonunu zaruri kılan nitelikte sorunlar olmalarıdır.

Kısacas1, COVID-19 salgını ile birlikte uluslararası sağlık hukukuna ilişkin küresel ölçekteki düzenlemelerin ve yapıların gündeme getirilip gözden geçirilmesi için bir firsat ortaya çıkmıştır. Uluslararası hukukun sınır aşan salgınlara ilişkin öngördüğü yükümlülükler, yetki paylaşımı ve usuller nelerdir, mevcut krizde bunlara uyulmuş mudur, uyulmadıysa bunun sebebi ve çözümü nedir, ayrıca uluslararası hukuk kurumlar aracılığıyla hangi role ve etkiye sahiptir, uluslararası hukukun mevcut rolü ve etkin düzenlemeler arttırılmalı mıdır yoksa azaltılmalı mıdır gibi sorular bu çerçevede irdelenmesi gereken önemli sorular olarak önümüzde durmaktadır. Bu makalenin amacı da yukarıda belirtilen tartışmalar ve sorgulamalar 1şığında, uluslararası sağlık hukukunda küresel salgın yönetimine ilişkin kurumsal mekanizmaların ve düzenlemelerin değerlendirilmesinin yanında aynı zamanda uluslararası hukukun diğer önemli alanlarını da incelemektir. İlk bölümde temel

\footnotetext{
8 'Challenges of Global Governance Amid the COVID-19 Pandemic' (CFR, Mayıs 2020) $<$ https://cdn.cfr.org/sites/default/ files/report_pdf/challenges-of-global-governance-amid-the-covid-19-pandemic.pdf> Erişim Tarihi 28 Mayıs 2020.

19 Tsung Ling Lee, 'Global Health in a Turbulence Time: A Commentary' (2020) 15(1) Asian Journal of WTO \& International Health Law and Policy 27, 29.

20 Kofi Annan, 'Problems without Passports' (Foreign Policy, 9 Kasım 2009) <https://foreignpolicy.com/2009/11/09/ problems-without-passports/> Erişim Tarihi 28 Mayss 2020.
} 
küresel sağlık yönetimi mercii ve salgınlarla uluslararası ölçekte mücadelenin odak noktası olan DSÖ'nün yapıs1 ve düzenlemeleri detaylı bir şekilde ortaya konulmaktadır. Özellikle hukuki bağlayıcılığı olan 2005 tarihli Uluslararası Sağlık Tüzüğ̈̈’nün (UST) hükümleri detaylı bir şekilde incelenmektedir. İkinci bölümde DSÖ’nün kurumsal mekanizmalarının ve düzenlemelerinin COVID-19 salgını bağlamında nasıl bir işlev gösterdiği değerlendirilmekte ve mevcut eksiklikler tespit edilmektedir. Ayrıca söz konusu eksikliklere yönelik çözüm önerileri sunulmaktadır. Son bölümde ise uluslararası hukukun sağlık hukuku dışında kalan ancak COVID-19 salgını ile doğrudan bağlantılı olarak öne çıkan uluslararası insan hakları hukuku, uluslararası ticaret hukuku ve uluslararası kolektif güvenlik alanlarındaki küresel yönetim mekanizmalarının oynadığı roller incelenmekte ve COVID-19'un bu alanlardaki etkisi ele alınmaktadır.

\section{Küresel Sağlık Yönetiminin ve Salgınla Mücadelenin Odağı: Dünya Sağlık Örgütü}

Uluslararası sağlık hukukunun önde gelen isimlerinden olan Lawrence Gostin bu alanı, "dünya nüfusunun ulaşılabilir en yüksek fiziksel ve zihinsel sağlık standartlarına ulaşılması için var olan normları, süreçleri ve kurumları şekillendiren hem bağlayıcı hem de bağlayıcı olmayan uluslararası hukuk araçlarından" müteşekkil alan olarak tanımlamaktadır. ${ }^{21}$ Uluslararası hukukun bu alanı günümüzde öncelikli olarak insanların sağlık hakkınının korunması amacına hizmet etmeyi hedeflemektedir. Sağlık hakkı, Evrensel İnsan Hakları Beyannamesi'nde açıkça tanınmış bir haktır. ${ }^{22}$ Ayrıca insan haklarına ilişkin en temel çok taraflı andlaşmalardan biri olan Ekonomik, Sosyal ve Kültürel Haklar Uluslararası Sözleşmesi bu hakk1 ihtiva etmektedir. ${ }^{23}$ Sözleşme'ye göre, taraf devletlerin bireylerin sağlıklı bir şekilde yaşamlarını sürdürebilmeleri için gerekli koşulları oluşturma yükümlülükleri vardır. ${ }^{24}$ DSÖ'nün 1978 tarihli Öncelikle Sağlık Hizmetleri’ne ilişkin Alma-Ata Bildirgesi sağlık hakkının temel bir insan hakkı olduğunun altını çizmiş ve "mümkün olan en yüksek sağlık seviyesine ulaşılmasının dünya çapındaki en önemli toplumsal hedeflerden biri olduğunu" ifade etmiştir. ${ }^{25}$

\footnotetext{
1 Lawrance Gostin, Global Health Law (Harvard University Press 2014) 59.

22 Evrensel İnsan Hakları Beyannamesi 10 Aralık 1948 UNGA Res 217 A(III) (UDHR) m 25.

23 Ekonomik, Sosyal ve Kültürel Haklar Uluslararası Sözleşmesi (1966) Birleşmiş Milletler Anlaşma Serileri vol 993 m 12.

24 Ekonomik, Sosyal ve Kültürel Haklar Komitesi, 'General Comment No 14: The Right to the Highest Attainable Standard of Health (Article 12 of the International Covenant on Economic, Social and Cultural Rights)' (Refworld, 11 Ağustos 2000) $<$ https://www.refworld.org/pdfid/4538838d0.pdf> Erişim Tarihi 16 Mayıs 2020, para 35.

25 'Declaration of Alma-Ata' (WHO, Eylül 1978) <https://www.who.int/publications/almaata declaration en.pdf.ua=1.> Erişim Tarihi 15 Mayıs 2020.
} 
Uluslararası sağlik hukukunun en kritik alanlarından biri ise salgınlarla mücadeledir. ${ }^{26}$ Tarih boyunca çeşitli salgın hastalıklarla mücadele eden ve birçok kez büyük kayıplar veren insanlık için 21. yüzylla girerken de kendisine en büyük tehdidi teşkil eden küresel sorunlardan biri bulaşıcı hastalıklar kaynaklı salgınlar olmaya devam etmektedir. AIDS (Acquired Immuno Deficiency Syndrome), ortaya çıkan tıbbi çözümlere rağmen hâlâ farklı sebeplerden ötürü varlığını sürdüren sıtma ve tüberküloz, Ebola virüsü salgınlarının yeniden görülmesi ve yeni grip türleri gibi birçok bulaşıcı hastalık varlığını devam ettirmektedir. Bu hastalıklar zincirine ise son olarak günümüzde etkili yeni bir koronavirüs türü olan COVID-19 eklenmiştir. ${ }^{27}$ Koronavirüsler, daha önce yine küresel sağlı̆̆1 tehdit eden MERS (Middle East Respiratory Syndrome) ve SARS gibi virüsleri içeren geniş bir virüs ailesidir. COVID-19 ise kaynağ1, bulaşıc1lık seviyesi, ve başkaca klinik özellikleri henüz net bir şekilde belirlenememiş olması itibariyle niteliği tam olarak bilinemeyen ${ }^{28}$ ancak günümüze kadar en az 5 milyon civarı insana bulaşması ve 300.000'den fazla insanın ölümüne sebep olması sebebiyle oldukça tehlikeli bir virüs türüdür. ${ }^{29}$ Henüz uluslararası toplumun bir önceki yüzyılda karşılaştığı en şiddetli salgın olarak kayıtlara geçen ve 50 milyondan fazla insanın ölümüne yol açan İspanyol Gribi ile mukayese edilebilecek bir ölçekte olmasa da kimilerine göre ufukta böyle bir ihtimal gözükmektedir. ${ }^{30}$ Esasında, COVID-19 tarzı tehlikeli bir virüs kaynaklı bir salgının ortaya çıkması uluslararası toplum için hiç beklenmeyen bir hadise olmayıp bilakis olas1 görülmekteydi. ${ }^{31}$ DSÖ, 2019 yılında yayımladığı küresel sağlığa en büyük on tehdit unsuru listesinde küresel bir grip benzeri salgına yer vermiştir. ${ }^{32}$ Nitekim COVID-19 ortaya çıtıktan sonra kısa bir süre içerisinde tüm dünyayı etkileyerek bu tahminleri doğru çıkarmış ve bir kez daha kamu sağlığı meselesi sınırları aşan, küresel bir sorun hâline gelmiştir.

Küresel sağlık yönetimi mekanizmalarının ve uluslararası sağlık hukukunun temel odağı konumundaki DSÖ, doğal olarak, COVID-19 salgını ile küresel ölçekteki mücadelenin ve uluslararası işbirliğinin temel platformu olmuştur. Ancak kamu sağlı̆̆ meselesinin uluslararası işbirliğine konu olması yeni ve DSÖ ile

26 Bu konuda genel çalışmalar için bkz David Fidler, 'The Globalization of Public Health: Emerging Infectious Diseases and International Relations' (1997) 5(1) Indiana Journal of Global Legal Studies 11; David Fidler, 'Return of the Fourth Horseman: Emerging Infectious Diseases and International Law’ (1997) 81 Minn L Rev 771.

27 'Coronavirus (COVID-19)’ $(C D C)<\mathrm{https}: / /$ www.cdc.gov/coronavirus/index.html > Erişim Tarihi 15 Mayıs 2020.

28 'About COVID-19'<http://www.emro.who.int/health-topics/corona-virus/about-covid-19.html> Erişim Tarihi 18 May1s 2020.

29 'WHO Coronavirus Disease (COVID-19) Dashboard' (WHO) <https://covid19.who.int.> Erişim Tarihi 18 Mayıs 2020.

30 David Morens, Jeffery Taubenberger, 'The Mother of All Pandemics Is 100 Years Old (and Going Strong)!' (2018) 108 American Journal of Public Health 1449, 1452.

31 'Statement of the Global Health Law Committee of the International Law Association regarding the COVID-19 Pandemic' ( ILA, 5 Nisan 2020) <https://www.ila-americanbranch.org/news/article/statement-of-the-global-health-law-committee-ofthe-international-law-association-regarding-the-covid-19-pandemic/> Erişim Tarihi 18 Mayıs 2020.

32 'Ten Threats to Global Health in 2019' (WHO) <https://www.who.int/news-room/feature-stories/ten- threats-to-globalhealth-in-2019> Erişim Tarihi 18 Mayıs 2020. 
başlamış bir olgu değildir. ${ }^{33}$ Uluslararası sağlık işbirliğinin 1851 yılında Paris'te gerçekleşen Uluslararası Sağlık Konferansı'nda başladığı kabul edilmektedir. ${ }^{34} \mathrm{Bu}$ Konferans, coğrafi kapsamı Avrupa ile sınırlı olsa da ilk uluslararası sağlık yönetimi mekanizmasının kurulması girişimi olması bakımından önemlidir. Konferans'ın amacı, Avrupa devletlerinin salgınlar karşısında devreye sokmak zorunda oldukları uluslararası seyahat ve ticarete yönelik son derece maliyetli kısıtlamaları maliyeti en düşük seviyeye indirecek şekilde uyumlu hâle getirmekti. ${ }^{35}$ Zira o dönemde devletlerin salgın zamanlarında en sık ve ivedi bir şekilde başvurduğu yöntemler, ülkelerine gelen yolcuları yahut gemileri karantinaya almaktı ve bu önlemlerin uluslararası bir koordinasyon olmaksızın yapılması Avrupa'nın ekonomik sisteminde ciddi aksaklıklara yol açmaktayd.$^{36} \mathrm{Bu}$ sebeple, 1851'deki girişimin salgınla mücadelede tam teşekküllü bir uluslararası işbirliği mekanizmasını ortaya koymayı hedeflemediğini ifade etmek gerekir. ${ }^{37}$ Öte yandan, Konferans'a katılan bazı devletlerin kendi karar alma yetkilerinden feragat etmeye yanaşmaması sebebiyle bu ilk Konferans hedefini yerine getirme bakımından başarısız olmuştur. ${ }^{38}$ İlk Konferans'1 takiben art arda yapılan konferanslarda 8 ayrı uluslararası anlaşma müzakere edilmiş ancak hiçbiri üzerinde uzlaşmaya varılamamıştır. ${ }^{39} \mathrm{Bu}$ dönemde yalnızca, çok sınırlı sayıda devletin taraf olduğu ve bir salgın hastalığa ilişkin bilinen ilk uluslararası andlaşma olan Phylloxera Vastatrix Sözleşmesi gibi bazı nadir somut uluslararası işbirliği örnekleri görülebilmektedir. ${ }^{40}$

Ancak söz konusu başarısızlık kalıcı olmamış ve ilk geniş katılımlı uluslararası sağlık anlaşması olan Uluslararası Sağlık Sözleşmesi, daha sonra seri hâlinde devam eden bu konferanslarda ortaya çıkarak 1892 yılında yürürlüğe girmiştir. ${ }^{41}$ Söz konusu anlaşmanın amacı kolera virüsü ile mücadeledir. Takip eden yıllarda yine kolerayla mücadele için ek uluslararası anlaşmalar da akdedilmiştir. 1897'de ilk defa genel olarak salgınla mücadeleyi amaçlayan bir uluslararası anlaşma akdedilmiş, ${ }^{42} 1903$ y1lında ise o zamana kadar yapılmış tüm anlaşmalar tek bir Uluslararası Sağlık

\footnotetext{
33 Allyn L Taylor, Douglas W Bettcher, 'International Law and Public Health' (2002) 80(12) Bull World Health Org. $923,923$.

34 Detaylı bilgi için bkz Valeska Huber, 'The Unification of the Globe by Disease? The International Sanitary Conferences on Cholera, 1851-1894' (2006) 49(2) The Historical Journal 453.

35 Neville M Goodman, International Health Organizations and Their Work (Churchill Livingstone, 1971) 38.

36 Armin von Bogdandy, Pedro A Villarreal, 'International Law on Pandemic Response: A First Stocktaking In Light of the Coronavirus Crisis' (2020) 7 Max Planck Institute for Comparative Public Law \& International Law (MPIL) Research Paper 1,3 .

37 Nitekim bu yaklașım 1910'lu yıllara kadar değişmemiș ve söz konusu değișim ancak bulaşıcı hastalıkların daha iyi anlaşılmasını sağlayan bazı bilimsel gelişmelerle paralel olarak yaşanabilmiştir, David Fidler, 'The Future of the World Health Organization: What Role for International Law?' (1998) Articles by Maurer Faculty 1080, 1085.

38 Goodman (n 35) 37-38.

39 Lawrance Gostin, 'World Health Law: Toward a New Conception of Global Health Governance for the 21st Century' (2005) 5 Yale J Health Pol'y L \& Ethics 413, 414-415.

40 Convention between Austria-Hungary, France, Germany, Portugal and Switzerland Respecting Measures to be Taken Against Phylloxera Vastatrix (1878) (159 CTS 203).

411892 tarihli Uluslararası Sağlık Sözleşmesi için bkz <https://www.loc.gov/law/help/us-treaties/bevans/m-ust000001-0359. pdf> Erişim Tarihi 19 Mayıs 2020.

42 Venedik Sağlık Sözleşmesi (1897).
} 
Sözleşmesi'nde bir araya getirilmiştir. 1903 yılı, Konferans’ın sürekli bir uluslararası sağlık bürosu kurma kararı alması itibariyle de önemlidir.

Öte taraftan, Avrupa dışında da uluslararası sağlık hukuku gelişim göstermiş ve Amerika'daki devletler 1902 yılında benzer bir işleve sahip "Pan Amerikan Sağlık Örgütü (Pan American Health Organization-PAHO)" adlı bir yap1 kurmuşlardır. ${ }^{43}$ Ayrıca 1907 yılında kıtalararası bir işbirliği zemini yaratan, bir sekreterliğe ve taraf devletlerin hükümet yetkililerinden oluşacak sürekli bir komiteyi ihtiva eden “Office International d'Hygiène Publique (OIHP)" kurulmuş ve OIHP'nin merkezi Paris olarak belirlenmiştir. Birinci Dünya Savaşı'na kadar aktif olarak faaliyete devam eden OIHP'nin Savaş sonrasında Milletler Cemiyeti'nin (MC) kurulmasıyla birlikte MC bünyesine katılması gündeme gelse de MC üyesi olmayan Amerika Birleşik Devletleri'nin (ABD) vetosu sebebiyle bu gerçekleşmemiştir. İşlevlerinden biri "hastalıkların engellenmesi ve kontrolüne ilişkin uluslararası kaygılara yönelik adımlar atmak" olan MC ayrıca kendi sağlık organizasyonunu (Sağlık Ofisi) kurmak durumunda kalmıştır. ${ }^{44}$ MC'nin bünyesindeki Sağlık Ofisi'nin kuruluşundan 1 yıl sonra, 1924'te kurulan Epizootiklere ilişkin Uluslararası Ofisi de burada belirtmek gerekir. $^{45}$

İkinci Dünya Savaşı ile birlikte ciddi ölçüde akamete uğrayan uluslararası alanda sağlık işbirliği, Savaş sonrasında ilga olan MC'nin yerine BM'nin kurulmasıyla birlikte tekrar canlanmıştır. Şubat 1946'da BM Ekonomik ve Sosyal Konsey, BM Genel Sekreteri'nden uluslararası sağlık işbirliğini kurumsallaştıracak bir yapının müzakere edilmesi için devletlere davette bulunması kararını almıştır. ${ }^{46}$ Aynı yılın Temmuz ayında Uluslararası Sağlık Konferansı toplanmış ve bu Konferans’ta Dünya Sağlık Örgütü'nün Anayasa'sı kabul edilerek BM üyesi 51 devlet ile BM üyesi olmayan 10 devlet tarafından imzalanmıştır. ${ }^{47}$ DSÖ, BM'nin bir uzmanlık kuruluşu statüsüne sahip kılınmıştır. ${ }^{48}$ OIHP ve PAHO, DSÖ’nün bünyesine dahil olmuştur. ${ }^{49}$ DSÖ Anayasası yürürlüğe girene kadar, daha önce OIHP'nin yürütmekte olduğu belli temel faaliyetleri gerçekleştirmesi için geçici bir komisyon kurulmuştur. $\mathrm{Bu}$

\footnotetext{
43 Genel bilgi için bkz Elizabeth Fee, Theodore Brown, '100 Years of the Pan American Health Organization' (2002) 92(12) American Journal of Public Health 1888.

44 Bu organizasyonun dayanak noktası için Milletler Cemiyeti Şartı (1919) m 23; Uluslararası alandaki genel kurumsallaşma eğiliminin asıl olarak 1. Dünya Savaşı sonrasında, MC döneminde güçlendiği olgusu için bkz David Kennedy, 'The Move to Institutions' 1987 8(5) Cardozo Law Review 841, 841-842.

45 International Agreement for the Creation at Paris of an International Office for Dealing with Contagious Diseases of Animals (1924).

46 Ekonomik ve Sosyal Konsey (UN, 1946-1948) <https://library.un.org/sites/library.un.org/files/itp/1430 201404101302204694093_0.pdf> Erişim Tarihi 17 Mayıs 2020, s 7.

47 Dünya Sağlık Örgütü Kurucu Anayasası için bkz ‘Dünya Sağlık Örgütü Anayasası' (WHO, Ekim 2006)<https://www.who. int/governance/eb/who_constitution_en.pdf> Erişim Tarihi 20 Mayıs 2020.

48 Ibid $\mathrm{m} 69$

49 Daha önce özerkliğini korumak noktasında 1srarcı olan Pan Amerikan Sağlık Örgütü’nün bütünleşme süreci çin bkz Tine Hanrieder, International Organization in Time (OUP 2015) 3. Bölüm.
} 
komisyonun işlevi, DSÖ’nün resmen kurulduğu 1948 yılına kadar devam etmiştir. ${ }^{50}$ DSÖ’nün temel karar organı olan Dünya Sağlık Meclisi'nin (DSM) ilk oturumu 24 Haziran 1948'de, Cenevre'de gerçekleştirilmiştir. ${ }^{51}$

DSÖ’nün temel amacı, uluslararası düzeyde sağlık normlarının geliştirilmesini sağlayacak ve uluslararası sağlık işbirliğini koordine edecek bir küresel kamu sağlığı mercii olmaktır. ${ }^{52} \mathrm{Bu}$ doğrultuda, DSÖ Anayasası açıkça "tüm halkların mümkün en yüksek sağlık seviyesine ulaşması" hedefini benimsemiştir. ${ }^{53}$ DSÖ’nün kuruluşu İkinci Dünya Savaşı sonrası dönemde kamu sağlığının küresel çapta geliştirilmesine ilişkin uluslararası toplum nezdindeki güçlü ve kolektif bir iradenin varlığını göstermektedir. ${ }^{54}$ Üye devletlerin, işlevini yerine getirebilmesi için DSÖ’ye verdiği ve birçok uluslararası örgütte mevcut olmayan ölçüde geniş kural yaratma (normatif) yetkisi bunu göstermektedir. ${ }^{55}$ Bugün DSÖ, BM'nin en büyük uzmanlık kuruluşu konumundadır. ${ }^{56}$ DSÖ'nün temel karar organı olan DSM'nin üçte iki oy çoğunluğuyla, taraf devletler için bağlayıcı olacak "sözleşmeler veya anlaşmalar" kabul etme yetkisi, ${ }^{57}$ ayrıca DSÖ’nün yapacağı ve DSM'de basit çoğunlukla kabul edilen bazı düzenlemelerin üye devletler için kendiliğinden bağlayıcı olma gücü vardır. ${ }^{58}$ Meğer ki üye devletler aksi yönde bir bildirim (opt-out) yapmış olsun. Söz konusu aksi bildirim, sözleşmeler ve anlaşmalar için bunların kabulünü takip eden 18 ay içerisinde, düzenlemeler için önceden bildirilen sürede yapılmalıdır. ${ }^{59}$ Bunlara ek olarak, Örgüt'ün bağlayıcı olmayan kimi rehber ilkeler, küresel stratejiler ve öneriler kabul etmesi de mümkündür. ${ }^{60}$ Tüm bu imkânlara sahip olan DSÖ, kuruluşundan itibaren ve günümüzde de geçerli olacak şekilde başta bulaşıcı hastalıklarla ve salgınlarla mücadele olmak üzere küresel sağlık meselelerine yönelik hukuki düzenlemelerin yapılması ve gerekli uluslararası işbirliğinin sağlanması noktasında temel merci konumundadır. ${ }^{61}$

\footnotetext{
${ }_{50}$ 'Origin and development of health cooperation' $(W H O)<$ https://www.who.int/global_health_histories/background/en/> Erişim Tarihi 20 Mayıs 2020.

51 'First World Health Assembly' $(W H O)<$ https://www.who.int/global_health_histories/first_world_health_assembly/en/> Erişim Tarihi 20 Mayıs 2020.

52 Dünya Sağlık Örgütü Anayasası (n 47) m 2.

53 Ibid $\mathrm{m} 1$.

${ }_{54}$ Gostin, Global Health Law (n 21) 91-92.

55 Allyn L Taylor, 'International Law and Public Health Policy' in Kris Heggenhougen vd (eds) International Encyclopaedia of Public Health (Academic Press 2008) 675; Lawrance Gostin, 'A Proposal for Framework Convention on Global Health' (2007) 10(4) Journal of International Economic Law 989, 994.

56 Gian Luca Burci, 'The World Health Organization at 70: Challenges and Adaptation' (2019) 16(2) International Organizations Law Review 229, 229.

57 Dünya Sağlık Örgütü Anayasası (n 47) m 19.

$58 \quad$ Ibid $\mathrm{m} 21$.

59 Ibid $\mathrm{m} 20,22$

60 Lawrence Gostin, Devi Sridhar, 'Global Health and the Law' (2014) (370) The New England Journal of Medicine 1732, 1734.

${ }^{61}$ DSÖ’nün günümüze kadar yaptığı hukuki düzenlemelerin önemli bir kısmının salgınların önlenmesi ve salgınlarla uluslararası ölçekte mücadele ile ilgili olduğu akılda tutulmalıdır, Fidler, 'The Globalization of Public Health: Emerging Infectious Diseases and International Relations' (n 26); Fidler, 'Return of the Fourth Horseman: Emerging Infectious Diseases and International Law' (n 26) 836-843; Burci (n 56) 231.
} 
DSÖ daha kuruluş yıllarını takip eden on yıllarda bulaşıcı hastalıklarla etkili bir mücadele uygulaması ortaya koymuş ve özellikle çiçek hastalı̆̆ının ortadan kaldırılmasında büyük bir başarı sergilemiştir. ${ }^{62}$ Ancak zaman içerisinde bulaşıcı olmayan bazı hastalık türlerinin bulaşıcı hastalıklardan daha büyük sorun teşkil ettiği yönünde bir kanaat ortaya çıkınca örgütün odağı bulaşıcı hastalıklardan ve salgınlardan farklı alanlara kaymıştır. ${ }^{63}$ Öyle ki örgütün 1980'li yıllarda ortaya çıan ve küresel çapta etkili olan AIDS salgını ile yeterli ve etkili bir mücadele ortaya koyamayacak kadar odağının kaymış olduğu belirtilmektedir. ${ }^{64}$ Bunun en büyük göstergesi, DSÖ'nün varlığına rağmen ayrıca BM AIDS Programı'nın (UNAIDS) kurulmuş olmasıdır. ${ }^{65} 1990$ 'lı yıllarda ise örgütün daha özel sektör eğilimli bir perspektif benimsediği eleştirileri ortaya çıkmış ve DSÖ'nün küresel sağlık yönetimindeki rolü ve otoritesi ciddi sorgulamalara tabi tutulmuştur. ${ }^{66}$

DSÖ’nün yukarıda belirtilen "kural koyucu (normatif) otoritesinin" bir ürünü olan Uluslararası Sağlık Tüzüğü, DSÖ’nün tarihinde özellikle üzerinde durulması gereken çok önemli bir husustur. ${ }^{67}$ Örgüt'ün nadiren başvurduğu ve DSÖ Anayasası'nın 21. maddesinde belirtilen düzenleme yapma yetkisine dayanarak ortaya koyduğu ilk düzenleme 1951 tarihinde kabul edilen Uluslararası Sağlığa Dair Tüzük'tür (International Sanitary Regulations). ${ }^{68} 1969$ tarihinde elden geçirilen bu metin Uluslararası Sağlık Tüzügü (International Health Regulations-IHR) adını almış ${ }^{69}$ ve daha sonra 1973 ile 1981 yıllarında bazı sınırlı güncellemelere tabi tutulmuştur. ${ }^{70}$ Ancak 21. yüzyıla gelindiğinde Uluslararası Sağlık Tüzüğü’nün hükümlerinin artık sahadaki gerçekliklere hitap etmediği, özellikle de salgınlarla mücadele noktasında yetersiz kaldığı olgusunun aşikâr hâle gelmesiyle birlikte 2005 y1lında büyük bir güncelleme yapılmıştır. ${ }^{71}$ Zira tüberküloz ve sıtma gibi bazı endemik hastalıkların yanı sıra AIDS gibi yeni hastalıklar 1969 tarihli Uluslararası Sağlık Tüzüğü’nün kapsamı

62 DSÖ’nün çiçek hastalığı ile mücadelesine ilişkin detaylar için bkz Kelley Lee, The World Health Organization (Routledge 2009) 46-70.

63 Simon Rushton, 'Global Governance Capacities in Health: WHO and Infectious Diseases' in Adrian Kay and Owain Williams (eds), Global Health Governance: Crisis, Institutions and Political Economy (Palgrave-MacMillan 2009) 60; Söz konusu değişim sürecinin detayları için bkz Mateja Steinbrück-Platise, 'The Changing Structure Of Global Health Governance' in Leonie Vierck, Pedro A Villarreal ve Katarina Weilert (eds), The Governance of Disease Outbreaks. International Health Law: Lessons from the Ebola Crisis and Beyond (Nomos 2017) 83-111.

64 Bogdandy ve Villarreal, 'International Law on Pandemic Response: A First Stocktaking In Light of the Coronavirus Crisis' (n 36) 5; daha genel bilgi için bkz Bradly Condon and Tapen Sinha, Global Lessons from the AIDS Pandemic. Economic Financial, Legal and Political Implications (Springer 2008).

65 'COVID-19 and HIV'<https://www.unaids.org/en> Erişim Tarihi 29 Mayıs 2020.

66 Steinbrück-Platise (n 63) 90-92.

67 Uluslararası Sağlık Tüzüğü hakkında kapsamlı bilgi için bkz Gostin, Global Health Law (n 21) 177-204.

${ }_{68} \mathrm{Bu}$ Düzenlemeler'in metni için bkz 'International Sanitary Regulations' <https://apps.who.int/iris/bitstream handle/10665/85636/Official_record37_eng.pdf? sequence=1\&isAllowed=y> Erişim Tarihi 10 Haziran 2020.

${ }^{69}$ Adam Kamradt-Scott, 'The International Health Regulations (2005) Strengthening Their Effective Implementation and Utilisation' (2019) 16 International Organizations Law Review 242, 243.

70 Gostin, 'World Health Law: Toward a New Conception of Global Health Governance for the 21st Century' (n 39 ) 415.

${ }^{71}$ İki USD'nin hükümlerinin detaylı bir mukayesesi için bkz David Fidler, 'From International Sanitary Conventions to Global Health Security: The New International Health Regulations' (2005) 4 Chinese Journal of International Law 325. 
dışında kalmaktaydı, çünkü tüzüğün kapsamındaki hastalıklar sınırlı sayıda olacak şekilde (kolera, veba, sarı humma, hemorajik ateş, tifüs, çiçek) belirtilmişti. ${ }^{72} \mathrm{Bu}$ da 1969 tarihli Uluslararası Sağlık Tüzüğü'nün kapsamının aradan geçen yüzyıldan fazla zamana rağmen neredeyse 1851 tarihindeki Uluslararası Sağlık Konferansı ile aynı kaldığını göstermektedir. ${ }^{73}$ Ayrıca taraf devletlerin bildirim yükümlülükleri ve bildirim mekanizmaları güncel ihtiyaçları karşılayacak kadar gelişkin değildi ${ }^{74}$ Taraf devletlerin hastalık gözlem ve tespit kapasitelerini geliştirmelerine yönelik basit bazı yükümlülüklerin ötesinde herhangi bir kapsamlı düzenleme yer almamaktaydı. ${ }^{75}$

Salgınlarla mücadele ile ilgili yeni ve son derece kritik hükümler içeren 2005 tarihli Uluslararası Sağlık Tüzüğü (UST) bugün COVID-19 salgını bağlamında sıkça gündeme gelmektedir. ${ }^{76} 196$ devletin akdettiği 2005 tarihli yeni UST, 1995'te DSM'nin aldığı kararla başlayan 10 yıllık bir çalışmanın ürünüdür. ${ }^{77} 66$ maddeden ve 9 ekten oluşan kapsamlı bir düzenleme olan 2005 tarihli UST, dönemin BM Genel Sekreteri tarafından, küresel sağlık yönetimi açısından daha önce emsali olmayan derecede önemli ve cesur bir düzenleme olarak nitelenmiştir. ${ }^{78}$ Zira 2005 tarihli UST, uluslararası toplumun kamu sağlığının korunması yolunda devletlerin egemenliğinin kısıtlandığı ve sınır aşan salgınların kontrolünde daha gelişkin kuralların geçerli olduğu bir küresel yönetim mekanizmasına kapıyı açmışır. ${ }^{79}$ Bu noktada önemle ifade etmek gerekir ki 2005 tarihli UST'nin ortaya çıkmasını hızlandıran, ayrıca Tüzük'te öngörülen bazı yeni mekanizmaların ve yükümlülüklerin arkasında yatan temel sebeplerden biri, Çin'in 2002 yllında patlak veren SARS krizinin yönetilmesi noktasında attığı yetersiz adımlardır. ${ }^{80} \mathrm{Bu}$ deneyimin de su yüzüne çıkardığı gereksinimlerle birlikte sadece tüzüğün kapsamı genişletilmekle kalınmamış, devletlere daha çok yükümlülük yükleyen, insan haklarında yaşanan gelişmelere daha çok uyum sağlayan ${ }^{81}$ ve DSÖ'nün yetkilerini arttıran bir muhtevaya sahip kılınmıştır.

'Uluslararası Sağlık Tüzüğü' (WHO, 2005) <https://www.who.int/ihr/publications/9789241580496/en/> Erişim Tarihi 21 Mayis 2020, m 1 .

73 Gostin, 'World Health Law: Toward a New Conception of Global Health Governance for the 21st Century' (n 39) 413, 415.

74 David Fidler, Lawrence O Gostin, 'The New International Health Regulations: An Historic Development for International Law and Public Health' (2006) 34(1) JL Med \& Ethics 85, 85.

75 Ibid 88.

76 'Uluslararası Sağl1k Tüzüğü' (n 72).

77 Fidler ve Gostin (n 74) 85.

78 BM Genel Sekreteri Kofi Annan'ın Basın Açıklaması, 'World Health Assembly's Revised Regulations “Bold and Necessary Step" to Protect Global Public Health, Says Secretary-General' (UN, 23 Mayıs 2005) < https://www.un.org/press/en/2005/ sgsm9886.doc.htm> Erişim Tarihi 21 Mayıs 2020.

79 Bogdandy ve Villarreal, 'International Law on Pandemic Response: A First Stocktaking In Light of the Coronavirus Crisis' (n 36).

$80 \quad$ Fidler ve Gostin (n 74) 85; David Heymann ve Guénäel Rodier, 'SARS: A Global Response to an International Threat' (2004) The Brown Journal of World Affairs (2004) 10(2) 185,185; Sara E Davies, Adam Kamradt-Scott ve Simon Rushton, Disease Diplomacy: International Norms and Global Health Security (Johns Hopkins University Press 2015) 43-73.

$81 \quad$ Fidler ve Gostin (n 74) 87. 
Yapıldığı dönemde salgınlarla mücadeleye yönelik uluslararası işbirliğinin en güncel ürünü olan 2005 tarihli UST'nin, küresel sağlığın korunması için son derece kapsamlı bir hukuki araç olduğu düşünülmüştür. Öyle ki 2005 y1lında getirilen temel yeniliklerden biri, 1969 tarihli UST kapsamında olmayan bazı yeni bulaşıcı hastalıkların tüzüğün kapsamına sokulmasıdır. 2005 tarihli UST'nin ilk maddelerinde ortaya konan son derece detaylı tanımlamalarla bu sağlanmıştır. ${ }^{82}$ Bir başka deyişle, 2005 tarihli UST hükümleri sınırlı sayıda hastalığa uygulanmayıp kaynağı ne olursa olsun uluslararası ölçekte yayılabilecek her türlü hastalığı kapsayacak bir şekilde oluşturulmuştur. Bu bakımdan, 2005 tarihli UST'yi son derece "aktüel ve devrimci" bir düzenleme olarak niteleyenler olmuştur. ${ }^{83}$ Dolayısıyla, COVID-19 salgını da 2005 tarihli UST'nin kapsamına girmektedir.

Uluslararası sağlık işbirliğine kapsamlı bir hukuki çerçeve katmayı ve DSÖ’nün koordinatör olarak odağında yer aldığı işbirliği zeminini genişletmeyi hedefleyen bu düzenlemenin temel amacı, uluslararası ölçekte yayılan ve kamu sağlığını tehdit eden hastalıkların, orantılı ve uluslararası seyahat ile ticaretin gereksiz ölçüde sekteye uğramayacağ1 yöntemlerle engellenmesi, kontrolü ve bu hastalıklardan korunmanın sağlanmasıdır. ${ }^{84}$ Kisacası, devletlerin kendi halklarının sağlığını koruma hakkı ile bu koruma için alınacak önlemlerin uluslararası ticareti ve seyahati ölçüsüz bir biçimde kısıtlamaması arasındaki dengenin kurulması hedeflenmiştir. ${ }^{85}$ $\mathrm{Bu}$ bakımdan, devletlere verilen bildirim yükümlülükleri 2005 tarihli UST'nin önemli sacayaklarından biridir. ${ }^{86}$ Söz konusu bildirim mekanizmasının hızlı bir şekilde işleyebilmesi için 2005 tarihli UST'nin 4. maddesi taraf devletlere kendi ülkelerinde DSÖ Ulusal İletişim Merkezleri'ne yer verme yükümlülüğü getirmekte ve bu merkezlerin her zaman açık olması gerektiğini belirtmektedir. 5. madde ise 1969 tarihli UST’deki büyük bir açığı kapatarak salgınla mücadelenin adeta köküne inmekte ve her şeyden önce, 2005 tarihli UST'nin yürürlüğe girişini takiben belli bir süre içerisinde taraf devletlerin kendi sağlık sistemlerini ve gözlem kapasitelerini geliştirmelerini bir yükümlülük olarak düzenlemektedir. Benzer yükümlülüklere, kamu sağlığı müdahalesine ilişkin 13. maddede de rastlanmaktadır. 6. maddeye göre, taraf devletler kendi ülkelerinde "uluslararası düzeyde halk sağlı̆̆1 acil durumu (public health emergency of international concern-PHEIC)," yani sadece ulusal ölçekte mücadele ile ortadan kaldırılması mümkün olmayan ve uluslararası salgına

\footnotetext{
82 'Uluslararası Sağlık Tüzüğü' (n 72) m 1-2.

83 'COVID-19 and International Law: What went wrong and what can we learn from it?' (BIICL, 16 Nisan 2020) <https:// www.biicl.org/documents/10303 covid19 and international law 16 april 2020 event report.pdf $>$ Erișim Tarihi 23 Mayıs 2020, s 5; Kashef Ijaz vd, 'International Health Regulations - What Gets Measured Gets Done' (2012) 18 Emerging Infectious Diseases 1054, 1054; USD kimilerince "salgınlarla mücadelede Vestfalyan olmayan stratejilerin ortaya konması" olarak nitelenmiştir, bkz Obifor Aginam, 'Globalization of Health Insecurity: The World Health Organization and the New International Health Regulations’ (2006) 25 Medicine \& Law 663, 672.

84 'Uluslararası Sağlık Tüzüğü' (n 72) Önsöz.

85 Fidler ve Gostin (n 74) 86.

86 'Uluslararası Sağlık Tüzüğ̈̈' (n 72) Bölüm 2; söz konusu yükümlülüklerin nasıl uygulanacağına dair detaylı bir şema için bkz 'Uluslararası Sağlık Tüzüğü’ (n 72) Ek-2.
} 
yol açma riski teşkil eden durumlarda ${ }^{87}$ DSÖ’yü Ulusal İletişim Merkezleri kanalıyla, mümkün olan en etkili yollarla ve acilen (24 saat içerisinde) bilgilendirmelidir. Bu bildirimi takiben söz konusu acil duruma ilişkin tüm gelişmeleri doğru bir şekilde ve zamanında aktarmaya devam etmelidir. Eğer beklenmeyen ve "uluslararası düzeyde halk sağllğı acil durumu" teşkil edebileceğine dair delillerin olduğu durumlar ortaya çıkarsa da taraf devletler için ayn yükümlülükler geçerlidir. ${ }^{88}$ Hatta 6. ve 7. madde uyarınca DSÖ'ye bildirim yapılması gereken bir durumun mevcudiyetine dair şüphe taşıyan taraf devletlerin DSÖ ile bir danışma ve yardım talep etme ilişkisi kurmasına olanak sağlanmıştır ki bu hükümle birlikte devletlerin özen yükümlülüğünün (due diligence) 2005 tarihli UST ile birlikte oldukça yüksek bir seviyeye çıkarıldığ rahatlıkla iddia edilebilir. ${ }^{89}$ Kısacası, söz konusu bildirim yükümlülükleri, 2005 tarihli UST'nin merkezinde yer alan oldukça önemli yükümlülüklerdir. Açıktır ki 2005 tarihli UST'nin temelinde ortak bir gözetim ve tehlikeyi erkenden tespit, risk durumunda acil uyarı, ve acil duruma uluslararası işbirliği içerisinde önlem geliştirme mantığı yatmaktadır.

2005 tarihli UST’nin bir başka öne çıkan özelliği, 9. maddeye göre, olası salgın uyarı konusunda sadece taraf devletlerin resmi mercilerinden değil, devletdışı aktörlerden gelen verileri de dikkate alma yetkisinin bulunmasıdır. 1969 tarihli UST'de böyle bir imkân söz konusu değildi. Aynı maddede, taraf devletlerin kendi toprakları dışında, yani başka devletlerin ülkelerinde DSÖ’ye bildirimi gerektirecek bir durum tespit ettiklerinde doğrudan DSÖ’ye bildirimde bulunma yetkisini ve yükümlülüğünü haizkılındıkları görülmektedir. ${ }^{90}$ Böylelikle, DSÖ’nün olası bir tehlike durumunu gecikmeksizin tespit edebilmesi için bilgi kaynaklarının olabildiğince çeşitlendirildiği görülmekte ve bu durumun devletleri 2005 tarihli UST'nin bildirim yükümlülüklerine uyma mecburiyetinde hissettirdiği belirtilmektedir. ${ }^{91}$ 9. maddede öngörülen kanallarla bildirim alan DSÖ’nün ilgili devlete (bildirime sebep olan sağllk tehdidinin ülkesinde ortaya çıktığ 1 iddia edilen devlete) bu bildirimlerin doğruluğunu teyit etmek üzere bilgi paylaşımı çağrısında bulunması ve işbirliğine girmesine ilişkin ve DSÖ’nün nihai bir değerlendirme yapana kadar tüm taraf devletlere -ve gerekli görülürse ilgili uluslararası örgütler ile kamuoyuna- söz konusu tehdide karşı hazırlıklı olmaları için yapacağı ilk bildirimin kapsamına dair hususlara takip eden maddelerde yer verilmektedir. ${ }^{92}$ Bu hükümlerden anlaşılmaktadır ki 2005 tarihli UST,

\footnotetext{
Lawrence Gostin vd, 'Ebola in the Democratic Republic of the Congo: Time to Sound a Global Alert?' (2019) 393 The Lancet 617, 618; detaylı bilgi için bkz David Fidler, 'To Declare or Not to Declare: the Controversy over Declaring a Public Health Emergency of International Concern for the Ebola Outbreak in the Democratic Republic of the Congo' (2019) 14(2) Asian J Wto \& Int'l Health L \& Pol'y 287, 287-330; Chang-Fa Lo, 'The Missing Operational Components of the IHR (2005) from the Experience of Handling the Outbreak of COVID-19: Precaution, Independence, Transparency and Universality' (2020) 15(1) Asian Journal of WTO \& International Health Law and Policy 1, 1-26.

88 'Uluslararası Sağlık Tüzüğü' (n 72) $m 7$.

89 Ibid $\mathrm{m} 8$.

90 'Uluslararası Sağlık Tüzüğü' (n 72) m 9(2).

91 Fidler ve Gostin (n 74) 90.

92 'Uluslararası Sağlık Tüzüğü' (n 72) m 10-11.
} 
etkili bir küresel sağlık yönetimi mekanizması kurulması ile devletlerin egemenlik alanlarının fazla daraltılmaması arasında hassas bir denge kurmaya çalışmıştır. ${ }^{93}$

Tüm bu kaynaklardan uyarıları ve verileri toplayan DSÖ’nün bir olay hakkında "uluslararası düzeyde halk sağlığı acil durumu" teşkil ettiğine ilişkin kararı nasıl ve hangi ölçütlere göre alacağı da 2005 tarihli UST'nin 12. maddesinde detaylı bir şekilde düzenlenmiş, çok katmanlı bir istişare mekanizması öngörülmüştür. Kararı verecek temel merci DSÖ Genel Direktörü'dür. Bir uluslararası örgüt yetkilisinin tek başına, önemli hukuki sonuçlar ${ }^{94}$ doğurabilecek bir karar alıp ilânda bulunmasının genelde pek rastlanmayan türde, önemli bir yetki ve devletlerüstü kamu otoritesinin kullanım biçimi olduğu belirtilmektedir.95 DSÖ’nün "uluslararası düzeyde halk sağlığı acil durumu" ilânı ve ayrıca salgın ilânı, ${ }^{96}$ devletlerin ve bölgesel örgütlerin itibar ettikleri ve bunların yönetim mekanizmalarına yön veren ilânlardır. ${ }^{97}$ Ayrıca bu ilân bir risk değerlendirmesinin sonucu olduğu için, tam etkisi az veya çok belirsiz olan tehlike durumlarında yapılmaktadır. ${ }^{98}$ Dolayısıyla, Genel Direktör'ün kayda değer derecede bir takdir marjı söz konusudur. Ancak önemle ifade etmek gerekir ki 12. maddede öngörülen çok katmanlı istişare mekanizmaları, bu mekanizmaların kararları nihayetinde bağlayıcı olmasa dahi uygulamada Genel Direktör'ün bu geniş yetki alanının daraltılmasını sağlamaktadır. Özellikle, farklı alanlardan ve çeşitli bölgelerden uzmanlardan oluşan Acil Durum Komitesi'nin (Emergency Committee) tavsiyeleri uygulamada oldukça etkilidir. ${ }^{99}$ Genel Direktörlerin bu zamana kadar Acil Durum Komitesi’nin tavsiyelerini her zaman takip ettiği gözlemlenmektedir. ${ }^{100}$

2005 tarihli UST'den önce Genel Direktör'ün böyle bir karar alma yetkisi açıkça tanınmamış, hatta 2003'teki SARS krizinde dönemin DSÖ Genel Direktörü acil

93 Öte yandan, söz konusu dengenin iyi kurulamadığı yönünde eleştiriler yöneltenler olmuştur, bkz Eric Mack, 'The World Health Organization's New International Health Regulations: Incursion on State Sovereignty and Ill-Fated Response to Global Health Issues' (2006-2007) 7 Chinese Journal of International Law 365, 377.

94 Uluslararası düzeyde halk sağlığı acil durumu ilânının bizzat kendisi UST'ye taraf devletlere ek bir yükümlülük getirmese dahi kimi ulusal veya bölgesel hukuki düzenlemeler bu ilâna kendi çerçevelerinde hukuki sonuçlar bağlamaktadır, Armin von Bogdandy, Pedro A Villarreal, 'Critical Features of International Authority in Pandemic Response: The WHO in the COVID-19 Crisis, Human Rights and the Changing World Order' (2020) 7(18) Max Planck Institute for Comparative Public Law \& International Law (MPIL) Research Paper 1, 4.

95 Pedro A Villarreal, 'Pandemic Declarations of the World Health Organization as an Exercise of International Public Authority: The Possible Legal Answers to Frictions Between Legitimacies' (2016) 7(1) Göttingen Journal of International Law 95, 125-126.

96 Salgın ilânı yetkisi ve ölçütleri doğrudan UST'de yer almayıp DSÖ’nün bir bașka Rehber Belgesi'nde detaylı bir șekilde ortaya konmaktadır, bkz Dünya Sağlık Örgütü, 'Pandemic Influenza Risk Management. A WHO Guide to inform \& harmonize national \& international pandemic preparedness and response' $(W H O, 2017)<\mathrm{https} / /$ bit.ly/3bdu588> Erişim Tarihi 2 Haziran 2020, s 25-26.

97 Bogdandy ve Villarreal, 'Critical Features of International Authority in Pandemic Response: The WHO in the COVID-19 Crisis, Human Rights and the Changing World Order' (n 94) 10.

98 Jacqueline Peel, Science and Risk Regulation in International Law (CUP 2010) 101.

99 Komite'nin yapısına ilișkin detaylar için bkz 'Uluslararası Sağlık Tüzüğü' (n 72) m 47-48.

100 Bogdandy ve Villarreal, 'International Law on Pandemic Response: A First Stocktaking In Light of the Coronavirus Crisis' (n 36) 13. 
durum ilânında bulunduğu için yetki aşımı yapmakla (ultra vires) suçlanmıştır. ${ }^{101}$ Ancak 2005'teki değişikliklerden sonra, bir olayın "uluslararası düzeyde halk sağlı̆̆ acil durumu" teşkil ettiğine yönelik karar verilmesi ve bunu takiben Genel Direktör'ün bazı sağlık önlemlerini ve seyahat vb. kısıtlamaları içeren geçici ve sürekli önlemler önerme yetkisi getirilmiştir. ${ }^{102}$ Hatta kimi durumlarda "uluslararası düzeyde halk sağlığı acil durumu” kararı alınmadan da DSÖ'nün uluslararası ticaret ve seyahatlere ilişkin bazı kısıtlamalar öneren kılavuzlar yayımlaması mümkündür ${ }^{103}$ ve bu önerilerin de hukuki niteliği hemen hemen aynıdır. ${ }^{104}$ Söz konusu önerilerin her vakanın kendi koşullarına göre şekillenmesi oldukça önemlidir. 2005 tarihli UST’nin 17. ve 18. maddelerinde önerilerin hangi ölçütlerin dikkate alınarak yapılacağı ve hangi konulara ilişkin olabileceği kapsamlı bir şekilde düzenlenmiştir. Tüm bu önlemlerin önerilmesinden sonra da taraf devletlerle olan dinamik bir işbirliği ve sürekli bildirim sürecinin devam etmesi öngörüldüğü için, zaman içerisinde gelişmeler değerlendirilerek bu önerilerin değiştirilmesi veya kaldırılması elbette mümkündür. ${ }^{105}$ Önemle ifade edilmelidir ki tüm bu kararlar tavsiye mahiyetinde olduğu için taraf devletler açısından bağlayıcı değildir. Öte yandan, 43. madde uyarınca, devletlerin bu tavsiyeleri kabul etmekle birlikte; 48 saat içerisinde, bilimsel verilere dayanan gerekçelerini bildirmek şartıyla tavsiyelerin ötesine geçen, daha sıkı önlemler alma hakk1 da mevcuttur.

2005 tarihli UST’nin 50. maddesine göre, “uluslararası düzeyde halk sağlı̆̆1 acil durumu" ilânına ve tavsiye edilecek önlemlere dair Genel Direktör'ün aldığı kararların daha sonradan gözden geçirilmesi için bir Teftiş Komitesi (Review Committee) kurulması mümkündür. Ancak ifade edilmelidir ki bu Komite'nin kurulması kararı ve üyelerinin seçimi Genel Direktör tarafindan gerçekleştirilmektedir. Ayrıca Komite temel olarak Genel Direktör'e tavsiyelerde bulunma yetkisinin ötesine geçen bir yetkiye sahip değildir. Komite raporlarının DSM'ye sunulması dahi Genel Direktör'ün kararına tabidir. ${ }^{106}$

2005 tarihli UST’nin bir diğer çok önemli özelliği, taraf devletlerin “uluslararası düzeyde halk sağlığı acil durumu" teşkil eden salgın vb. durumlarda devreye sokabilecekleri sağlı önlemlerinin hukuki çerçevesini son derece detaylı bir şekilde çizmesi ve DSÖ’ye bu noktada oldukça belirgin bir koordinasyon mercii görevi vermesidir. 2005 tarihli UST’nin 5. Bölümü, bu tip durumlarda uluslararası ticaret ve

\footnotetext{
${ }_{101}$ Christian Kreuder-Sonnen, Emergency Powers of International Organizations. Between Normalization and Containment (OUP 2019) 155-156; daha geniş bilgi için bkz Fidler, 'From International Sanitary Conventions to Global Health Security: The New International Health Regulations' (n 71) 362-365.

102 'Uluslararası Sağlık Tüzüğü' (n 72) m 15-16.

103 Fidler, 'To Declare or Not to Declare: the Controversy over Declaring a Public Health Emergency of International Concern for the Ebola Outbreak in the Democratic Republic of the Congo' (n 87) 294.

104 Bogdandy ve Villarreal, 'International Law on Pandemic Response: A First Stocktaking In Light of the Coronavirus Crisis' (n 36) 15.

105 'Uluslararası Sağlık Tüzügü' (n 72) m 53.

106 'Uluslararası Sağlık Tüzüğü’ (n 72) m 52-53.
} 
seyahatin ölçüsüz sınırlamalara maruz kalmamasına ilişkin düzenlemelerin yer aldığı temel kısımdır. Kısacası, 2005 tarihli UST ile bir yandan DSÖ Genel Direktörü'ne gerekli şartlar oluştuğunda uluslararası işbirliğini harekete geçirecek şekilde acil duruma karar verme ve DSÖ’ye çok katmanlı istişare mekanizmaları ile birlikte bu acil duruma rehberlik etme rolü verilmiş, öte yandan ise taraf devletlerin kendi egemen yetkilerine dayanarak alabilecekleri önlemlerin çerçevesi belirlenmiştir. ${ }^{107}$ $\mathrm{Bu}$ bölümde yer alan 12 maddede taraf devletlerin alabilecekleri kamusal sağllk önlemlerinin şartları ve sınırları detaylı bir şekilde ortaya konmaktadır. Öyle ki taşımacılar, yolcular, mallar ve konteynırlar için ayrı ayrı hükümler yer almaktadır. Örneğin, 32. maddeye göre, yolculara yönelik alınacak önlemlerin insanlık onuru, insan hakları, ve temel hürriyetlere saygılı olması gereklidir. 34. ve 40. maddeler arasındaki kısımdan oluşan 6. Bölüm ise 5. Bölüm ile bağlantılı olarak, bir devletin ülkesine giriş yapan kişilerden istenebilecek sağlık belgelerine ilişkin olup 40 . maddede ise devletlerin aldıkları sağlık önlemlerinin masraflarını ülkelerine giriş yapan yolculara yansitamayacakları belirtilmektedir.

2005 tarihli UST’nin 8. Bölümü’nde bazı genel hükümler düzenlenirken, söz konusu bölümün ilk maddesi olan 42. maddeye özellikle dikkat çekilmelidir. $\mathrm{Bu}$ maddeye göre, taraf devletler bir sağlık önlemi aldıkları zaman bunu gecikmekzisin, şeffaf bir biçimde ve ayrımcılıktan kaçınarak uygulamalıdırlar. Ancak 2005 tarihli UST'nin dikkat çeken bir özelliği şudur ki taraf devletlerin buraya kadar yukarıda sayılan yükümlülükleri ihlal etmesi durumunda ne tür bir yaptırıma maruz kalacağına yönelik bir hükme yer verilmemiştir. ${ }^{108} \mathrm{Bu}$ sebeple, zamanında bildirim yapma gibi bağlayıcı olan yükümlülüklerin ihlali durumunda ancak uluslararası hukukun genel sorumluluk kuralları gündeme gelecektir.

Özellikle üzerinde durulması gereken bir diğer madde, 2005 tarihli UST'nin 10. ve son bölümünde yer alan 56. maddedir. 56. madde, 2005 tarihli UST çerçevesindeki uyuşmazlıkların çözümüne ilişkindir. Taraf devletlerin arasında bir uyuşmazlık çıkması durumunda, tarafların öncelikli olarak barışç1 yollarla ve müzakere ile sorunu çözmeleri beklenmektedir. ${ }^{109} \mathrm{Bu}$ şekilde çözüme ulaşılamaması hâlinde tarafların, uyuşmazlığın çözümünü DSÖ Genel Direktörü'ne havale etmesi mümkündür. ${ }^{110}$ Ayrıca tarafların, uyuşmazlıkların çözümünde zorunlu tahkimi veya başka uyuşmazlık çözüm mekanizmalarını kabul etmeleri de mümkündür. ${ }^{111}$ Bizzat DSÖ ile taraf devletler arasında bir uyuşmazlık çıkması durumunda ise mesele

\footnotetext{
107 Alexandra L Phelan vd, 'The Novel Coronavirus Originating in Wuhan, China: Challenges for Global Health Governance' (2020) 323(8) Journal of American Medical Association 709, 710.

108 Kamradt-Scott (n 69) 251.

109 Uluslararası Sağlık Tüzüğü (n 72) m 56 (1)

110 Ibid m 56 (2).

111 Ibid m 56 (3)-(4).
} 
DSM'ye iletilecektir. ${ }^{12}$ Ancak tüm bu uyuşmazlık çözüm yollarının işletilmesi tamamen tarafların rızalarına bağlıdır ve söz konusu hükümler zorlayıcı değildir.

Öte yandan, DSÖ’nün sahip olduğu ve yukarıda bahsedilen geniş yetkilerini kullandığı tarihi örnekler sınırlı sayıdadır. "Uluslararası düzeyde halk sağlığı acil durumu" bu zamana dek altı kez ilân edilmiştir: Domuz gribi (2009), vahşi çocuk felci virüsü (2014), Batı Afrika'daki Ebola (2014), Zika (2016), Demokratik Kongo Cumhuriyeti'ndeki Ebola (2019) ve son olarak COVID-19 salgınında. DSÖ'nün kanun koyucu yetkilerine dayanarak yaptığı düzenleme sayısı da pek fazla değildir. DSÖ'nün yetkilerini kullanma noktasındaki bu ihtiyatlı tavrının, tarihte inisiyatif aldığı birçok dönemde kendisini uluslararası siyasi tartışmaların ve çekişmelerin odağında bulmasından kaynaklandığı söylenebilir. ${ }^{113}$ Nitekim COVID-19 salgınında da DSÖ'nün attığı ve atmadığı adımlar yine büyük tartışmalara konu olmakta, örgüt ciddi ithamlarlarla karşs karşıya kalmaktadır. Dolayısıyla, Genel Direktör'ün rolü, DSÖ'nün yapısı ve 2005 tarihli UST'nin yeterliliği gibi birçok mesele çeşitli açılardan sorgulamalara konu olmaktadır. Tüm bu tartışmaları detaylı bir şekilde değerlendirebilmek için COVID-19 salgını süresince DSÖ’nün faaliyetlerini ve örgüte yönelik eleştirileri ele almak gereklidir.

\section{COVID-19 Salgınında Dünya Sağlık Örgütü’nün Rolü}

\section{A. Dünya Sağlık Örgütü'nün COVID-19 Salgını Süresince Attığı Adımlar}

DSÖ’ye COVID-19 virüsüne ilişkin Çin tarafından yapılan ilk resmi bildirimin 31 Aralık 2019' da gerçekleştiği bilinmektedir. ${ }^{114}$ Söz konusu bildirim, DSÖ’nün Çin' deki ulusal ofisine yapılmış ve sonrasındaki günlerde DSÖ, Çin'in yetkili mercilerinden yapılan bildirimler yoluyla süreci takip etmeye başlamıştır. İlk bildirimden iki hafta sonra, 14 Ocak 2020'de DSÖ’nün Çin yetkililerinin söz konusu virüsün insandan insana geçtiğine yönelik bir delilin bulunmadığı yönündeki bulgularını kabul ederek ilân etmesinin sebebi budur. Ancak bu ilândan sadece 8 gün sonra Çin aksi yönde bir bildirim yapınca, 23 Ocak'ta COVID-19'un insandan insana geçen bir virüs olduğu DSÖ tarafindan kabul edilmiş ve devletlere havalimanlarında denetimlerin yapılması şeklinde geçici önlemin alınması tavsiye edilmiştir. Aynı zamanda, Acil Durum Komitesi, Genel Direktör tarafından toplantıya çağrılmıştır. Fakat bu toplantının sonucunda, Komite içerisindeki fikir ayrılıklarından ötürü "uluslararası düzeyde halk sağlığı acil durumu" ilân etme kararı çıkmamıştır. Bu yöndeki bir karar ancak Çin dışında da insandan insana bulaşma vakaları bildirilince, 30 Ocak

\footnotetext{
112 Ibid m $56(5)$.

113 Lee (n 19) 44

114 Bu bildirim ve devamındaki tüm gelişmelerin detaylı bir zaman çizelgesi için bkz 'WHO Timeline - COVID-19' (WHO) $<$ https://www.who.int/news-room/detail/27-04-2020-who-timeline---covid-19> Erişim Tarihi 24 Mayıs 2020.
} 
2020 tarihinde çıkabilmiştir. ${ }^{115}$ Söz konusu kararla "uluslararası düzeyde halk sağlığı acil durumu" ilân edilince, DSÖ bir acil durum eylem plânı da yayımlamış ve tüm devletlere ortaya çıkan yeni virüsün teşkil ettiği risk karşısında hazır olma çağrısı yapmıştır. ${ }^{116}$ Devletlerin yeni virüsün tespitine, gözetim mekanizmaları kurmasına, ve iletişim kanallarına dair bazı öneriler sunan bu acil eylem plânının ardından, 12 Şubat'ta daha detaylı bir operasyonel plân yayımlanmıştır. ${ }^{117}$ Bu ikinci plânda aşı ve tedavi çalışmaları için bir Ar-Ge (Araştırma ve Geliştirme) şablonu da ortaya konmuş, ayrıca DSÖ'nün doğrudan saha araştırmalarının yoğunlaştırılması yönünde adımlar atılmıştır. ${ }^{118} \mathrm{Bu}$ adımlarla birlikte Çin devleti ile işbirliği hâlinde Çin'de saha araştırmaları yapmak üzere kurulan ve birçok devletten uzmanlardan oluşan DSÖ-Çin Ortak Misyonu 16 Şubat'ta göreve başlamış ve misyonun sonuç raporu 24 Şubat'a kadar süren görevinin ardından 28 Şubat'ta yayımlanmıştır. ${ }^{119} \mathrm{Bu}$ raporda tüm devletlere insandan insana bulaşmayı en aza düşürmek amacıyla "tavizsiz ve katı önlemler" alma çağrısı yapılmıştır. ${ }^{120} 5$ Mart'ta da tüm devletlere geniş çaplı testler uygulama tavsiyesi yapılmıştır. Süreçteki en kritik tarihlerden biri ise 11 Mart’tır. Zira bu tarihte DSÖ, COVID-19'un korkutucu derecede yayılması, şiddeti ve devletlerin endişe verici seviyedeki eylemsizliği sebebiyle kaygılarını ortaya koymuş ve acil durum tepki mekanizmalarının daha yüksek seviyeye çekilmesi gerektiğini vurgulayarak COVID-19'un bir salgın statüsünde olduğunu ilân etmiştir. ${ }^{121}$ Özellikle bu noktadan sonra, art arda birçok devlet sıkı kısıtlamaları devreye sokmuş ve olağanüstü hâl önlemleri almıştır. DSÖ tarafından 13 Mart’ta "COVID-19 Dayanışma Fonu" kurulmuş, ${ }^{122} 18$ Mart'ta ise uluslararası ölçekte kapsamlı ve hızlı veri paylaşımını sağlamak için klinik bir dayanışma programı başlatılmıştır. ${ }^{123}$

\footnotetext{
115 'Statement on the Second Meeting of the International Health Regulations (2005) Emergency Committee Regarding the Outbreak of Novel Coronavirus (2019-nCoV)' (WHO, 30 Ocak 2020) $<$ https://www.who.int/news-rooni/detail/30-01-2020statement-on-the-second-meeting-of-the-intern ational-health-regulations-(2005)-emergency-committee-regarding-theoutbreak-of-novel-coronavi rus-(2019-ncov)> Erişim Tarihi 24 Mayıs 2020.

116 '2019 Novel Coronavirus (2019-nCoV): Strategic Preparedness And Response Plan’ (WHO, 4 Şubat 2020) <https://www. who.int/docs/default-source/coronaviruse/srp-04022020.pdf.> Erişim Tarihi 25 May1s 2020.

117 'COVID-19 Strategic Preparedness and Response Plan: Operational Planning Guidelines to Support Country Preparedness and Response' (WHO, 12 Şubat 2020) <https://www.who.int/docs/default-source/coronaviruse/covid-19-sprp-unctguidelines.pdf?sfvrsn=81ff43d8_4> Erişim Tarihi 25 Mayıs 2020

118 'World Experts and Funders Set Priorities for COVID-19 Research' (WHO, 12 Şubat 2020) <https://www.who.int/newsroom/detail/12-02-2020-world-experts-and-funders-set-priorities-for-co vid-19-research.> Erişim Tarihi 25 Mays 2020.

119 'Report of the WHO-China Joint Mission on Coronavirus Disease 2019 (COVID-19)' (n 3).

120 Ibid 19

121 'WHO Director-General's opening remarks at the media briefing on COVID-19' (WHO, 11 Mart 2020) <https://www. who.int/dg/speeches/detail/who-director-general-s-opening-remarks-at-the-media-briefing-on-covid-19---11-march-2020> Erişim Tarihi 25 Mayıs 2020.

122 'COVID-19 Solidarity Response Fund' (WHO) < https://www.who.int/emergencies/diseases/novel-coronavirus-2019/ donate> Erişim Tarihi 25 Mayıs 2020.

123 Ibid.
} 


\section{B. Dünya Sağlık Örgütü’nün COVID-19 Salgını Süresince Attığı Adımlara Yönelik Eleştirilerin Değerlendirilmesi ve Çözüm Önerileri}

COVID-19 salgınının yönetimi noktasında DSÖ’nün attığ1 veya atmadığı adımlar ciddi eleştirilere maruz kalmaktadır. Bir tür DSÖ şüpheciliği had safhaya erişmiş, kimi devletler DSÖ’ye verdiği finansmanı kesme tehdidinde bulunmaktan ${ }^{124}$ ülkesindeki DSÖ yetkililerini kovmaya kadar farklı tepkiler vermişlerdir. ${ }^{125}$ Esasında, daha önce de ortaya konduğu üzere, DSÖ’ye yönelik eleştiriler yeni değildir. Örgüt’e yönelik ilk ciddi eleştirilerin 1980'li yıllarda hızla yayılan AIDS ile mücadeledeki eksiklikler çerçevesinde yöneltildiği görülmektedir. ${ }^{126}$ Daha sonra yaşanan başkaca gelişmelerle birlikte sadece devlet uygulamalarında değil, doktrinde de DSÖ’nün gitgide etkisiz ve işlevsiz bir kurum hâline geldiğine ilişkin eleştiriler zaman zaman ortaya konmuştur. ${ }^{127}$ Hatta DSÖ’yü "her şeyi bilen ancak hiçbir şey yapmayan” bir kurum olarak niteleyenler olmuştur. ${ }^{128}$

Gerçekten de COVID-19 salgını öncesindeki en yakın tarihli salgınlardan biri olan 2014'te başlayan Ebola virüsü salgınında, DSÖ’nün gerekli adımları atmakta yavaş kaldığına dair bir kanaat mevcuttur. ${ }^{129}$ Halbuki günümüzden neredeyse 20 yıl önceki SARS salgınında Çin yönetiminin COVID-19 salgınındakine çok benzer refleksler göstermesi sebebiyle uluslararası kamu sağlı̆̆ının korunması ciddi tehlikeye girmiş ve Çin'in SARS krizindeki tutumu karşısında DSÖ’nün etkisini ve manevra alanını arttıracak düzenlemeler yürürlüğe sokulmuştur. ${ }^{130}$ DSÖ'nün yetkisini arttırdığı düşünülen bu düzenlemelere rağmen Ebola ve şımdi COVID-19 salgınında gerekli adımların atılamamış olması ister istemez DSÖ’nün yönetim performansını birçok açıdan eleştirilere açık hâle getirmiştir.

Detaylı bir değerlendirme yapılacak olursa, somut eleştirilerin başında Çin’in ilk resmi bildirimini 31 Aralık 2019'da yapmış olmasına rağmen, Acil Durum Komitesi'nin toplanmasının üç hafta almış olması gelmektedir. Bu gecikme, Çin' in ilk bildiriminden sonraki süreçte COVID-19'un insandan insana bulaşıp bulaşmadığının belirgin olmamasıyla açıklansa da ne olursa olsun üç haftalık bir sürenin ciddi bir gecikme olduğuna dair kanaat hâlâ mevcuttur. ${ }^{131}$

\footnotetext{
${ }_{124}$ Teo Armus, 'Trump threatens to permanently cut WHO funding, leave body if changes aren't made within 30 days' (Washington Post, 19 Mayis 2020) <https://www.washingtonpost.com/nation/2020/05/19/who-funding-trump/> Erişim Tarihi 25 Mayıs 2020.

125 Burundi hükümetinin bu yöndeki kararı için bkz 'UPDATE 2-Burundi kicks out WHO team amid election campaign' (Reuters, 14 Mays 2020) <https:/www.reuters.com/article/health-coronavirus-burundi/update-1-burundi-expels-nationalwho-head-during-election-campaign-idUSL8N2CW2LB> Erişim Tarihi 26 May1s 2020.

126 Bogdandy ve Villarreal, 'International Law on Pandemic Response: A First Stocktaking In Light of the Coronavirus Crisis' (n 36) 5 .

127 Lee (n 19) 31; Gostin, 'A Proposal for Framework Convention on Global Health' (n 55) 993.

128 Lee, The World Health Organization (n 62) 82.

129 Clare Wenham, 'Public-health Experts Question Whether the WHO Has Been Too Deferential to China in Its Handling ofthe New Virus'(2017) 372 Phil Transactions Royal Soc B 1, 1-2.

130 Yanzhong Huang, 'The Sars Epidemic And Its Aftermath In China: A Political Perspective' $(N C B I)<$ https://www.ncbi. nlm.nih.gov/books/NBK92479/> Erişim Tarihi 26 Mayıs 2020; Tom Christensen, Martin Painter, 'The Politics of SARS Rational Responses or Ambiguity, Symbols and Chaos?' (2004) 23 Politics and Society 18, 18.

131 'COVID-19 and International Law: What went wrong and what can we learn from it?' (n 83) s 7.
} 
İlkiyle bağlantılı bir diğer önemli eleştiri ise DSÖ’nün 2005 tarihli UST'deki düzenlemelerle birlikte, uluslararası kamu sağlığını ilgilendiren bir mesele ortaya çıktı̆̆ında sadece devletlerin resmi mercilerinden gelen bildirimlerle kendisini sınırlamak zorunda olmadığı ve devletdışı aktörlerden (özel medya organları, sivil toplum kuruluşları, meslek birlikleri vb.) izlenen bilgileri de dikkate alabileceği ve alması gerektiği hususuyla alakalıdır. Buna göre, Çin yetkilileri 2019 yılının sonunda resmi bildirim yapmış olsa da bunun öncesinde COVID-19'un niteliğine ilişkin kamuoyuna yansımış ve son derece kayda değer bilgilerin ve olayların dikkate alınması gerekirdi. ${ }^{132}$ DSÖ daha erken harekete geçilmesi noktasında bu son derece etkili olabilecek yetkisini kullanmamış gözükmektedir. ${ }^{133}$

DSÖ’nün gerekli adımları atmakta geciktiğine ilişkin bir başka eleştiri, örgütün COVID-19'un salgın statüsünde olduğunu ilân etmek için 11 Mart'a kadar beklemiş olmasıdır. O tarihe kadar zaten 114 devletin 100.000 'den fazla vaka rapor etmiş olması, durumun vahametinin DSÖ tarafından zamanında kavranamadığı eleştirilerini güçlendirmektedir. ${ }^{134}$

En önemli eleştirilerden biri, DSÖ’nün uluslararası toplumun birçok kesimince salgına yönelik iyi bir yönetim sergilememekle ve yükümlülüklerini yerine getirmemekle itham edilen Çin'i olumlayan açıklamalarda bulunmuş olmasıdır. Çin'in aldığı ve hızla devreye soktuğu sıkı önlemler doğrudan DSÖ Genel Direktörü tarafından övgüyle karşılanmıştır. ${ }^{135}$ DSÖ-Çin Ortak Komitesi, Çin'in tarihteki belki "en azimli, seri ve atılgan salgın önleme gayretini”" ortaya koyduğunu rapor etmiş̧ir. ${ }^{136}$ Komite, Çin'in salgını önlemedeki "cesur yaklaşımının” gidişatı olumlu anlamda değiştirdiğini söylemiştir. ${ }^{137}$ Böylelikle, DSÖ’nün bu tip Çin’i savunur gibi gözüken açıklamalarda bulunması, Çin'i eleştiren geniş kesimler nezdinde Çin ve DSÖ ilişkisinin gündeme gelmesine yolu açmış, örgütün bağımsızlığı, hatta DSÖ

\footnotetext{
132 Bu çerçevede özellikle Tayvanlı sağlık yetkililerin yaptıkları uyarılara dikkat çekilmektedir, bkz 'Fighting the Coronavirus Pandemic: China's Influence at the World Health Organization' (IM, 23 Mart 2020) $<$ https://www.institutmontaigne.org/en/ blog/fighting-coronavirus-pandemic-chinas-influence-world-health-organization> Erişim Tarihi 27 Mayıs 2020.

133 'COVID-19 and International Law: What went wrong and what can we learn from it?' (n 83) s 6.

134 'Fighting the Coronavirus Pandemic: China's Influence at the World Health Organization' (n 132).

135 DSÖ Genel Direktörü, 'IHR Emergency Committee on Novel Coronavirus (2019-nCoV)', WHO, 30 Ocak 2020)<https:// www.who.int/dg/speeches/detail/who-director-general-s-statement- on-ihr-emergency-comnmittee-on-novel-coronavirus(2019-ncov) > Erişim Tarihi 28 Mayıs 2020; DSÖ Genel Direktörü Adhanom Ghebreyesus "China is actually setting a new standard for outbreak response"; ayrıca bkz Thomas Bollyky, Vin Gupta, 'What World Can Learn from China's Experience with Coronavirus?'(Foreign Affairs, 2 Mart 2020) < https://www.foreignaffairs.com/articles/china/2020-03-02/what-worldcan-learn-chinas-experience-coronavirus $>$ Erişim Tarihi 28 Mayıs 2020.

136 'Report of the WHO-China Joint Mission on Coronavirus Disease 2019 (COVID-19)' (n 3) 16.

137 Ibid 17.
} 
Genel Direktörü'nün Çin ile olan kişisel bağları sorgulanmaya başlanmıştır. ${ }^{138}$ DSÖ’nün uluslararası toplumun geneli için güvenilir bir merci olarak görülmesinin çok önemli olduğunun ve bağımsızlığına yönelik bir şüphenin ciddi yansımalarının olacağının altı çizilmektedir. ${ }^{139}$

Göründüğü kadarıyla, şu an DSÖ, Çin ile olan yoğun ilişkilerini işlevselliğini sürdürecek şekilde muhafaza etmek ${ }^{140}$ ile kendi ahlaki ve hukuki otoritesini muhafaza etmek arasındaki ince bir ipte yürümek durumunda kalmıştır. ${ }^{141}$ Henüz yakın bir tarihte, 18 Mayıs’ta ABD Başkanı'nın DSÖ Genel Direktörü'ne gönderdiği mektup, örgüte karşı eleştirel konumda bulunanların ithamlarının ulaşabileceği seviyeyi gözler önüne sermektedir. ${ }^{142}$ Genel olarak ise DSÖ'nün 2005 'ten sonra sahip olduğu daha geniş ve kural koyucu yetkilerini kullanmakta bir kez daha oldukça çekingen davranmasının, örgütü küresel sağl1k yönetimine liderlik edebilecek bir konumdan ziyade salt teknik bir kuruma dönüştürdüğü eleştirileri güçlendirdiği söylenebilecektir. ${ }^{143}$

DSÖ açısından meseleye bakıldığında öncelikle şu tespiti yapmak hakkaniyetli olacaktır: Ne kadar küresel sağlık yönetiminin odak mercii konumunda olursa olsun DSÖ bir uluslararası örgüt olarak kendisine üye devletlerin işbirliği yapma iradesine bağlı durumdadır. Bu gerçeğin salgın yönetimi ve 2005 tarihli UST özelindeki yansıması ise devletlerden bilgi akışı olmadan işlevsel bir küresel yönetimin ve koordinasyonun neredeyse imkânsız oluşudur. Zaten 2005 tarihli UST, tarihsel olarak ekonomik kaygılardan ötürü kendi ülkelerinde ortaya çıkan salgınları bildirme konusunda pek istekli olmayan devletlerin şeffaflı̆̆ı, bilgi paylaşımını ve iletişim kanallarını arttırması temelinde tasarlanmıştır. Bu bakımdan DSÖ’ye yöneltilecek suçlamalar sınırlı olabilecektir, zira DSÖ’nün üye devletlerin ülkelerinde zorlayıcı bir şekilde veri ve bilgi toplayacak bir kurumsal yetkisi söz konusu değildir. Devletlerin

\footnotetext{
138 Kathy Gilsinan, 'How China Deceived the WHO' (The Atlantic, 12 Nisan 2020) <https://www.theatlantic.com/politics/ archive/2020/04/world-health-organization-blame-pandemic-coronavirus/609820/> Erişim Tarihi 28 Mayıs 2020; Chris Pleasance, 'How the man running World Health Organisation trashed by Trump as China-centric is a career politician who worked for a Communist junta and became WHO's first NON-doctor Director-General 'following intense lobbying from Beijing" (DailyMail, 8 Nisan 2020) <https:/www.dailymail.co.uk/news/article-8199719/Dr-Tedros-Ghebreyesuscareer-politician-running-China-centric-WHO.html> Erişim Tarihi 28 Mayıs; Abhijit Iyer-Mitra, 'WHO and China covered Tedros' past — but what is worrying is how India fell for it' (ThePrint, 13 Nisan 2020) <https://theprint.in/opinion/whoand-china-tedros-past-worrying-how-india-fell-for-it/400945/> Erişim Tarihi 28 Mayıs 2020; Kate Kelland, Stephanie Nebehay, 'Caught in Trump-China feud, WHO leader under siege' (The Japan Times, 16 Mayis 2020) <https://www. japantimes.co.jp/news/2020/05/16/asia-pacific/us-donald-trump-china-who-tedros-adhanom-ghebreyesus/> Erişim Tarihi 28 Mayis 2020; Bradley A Thayer, Lianchao Han, 'China and the WHO's chief: Hold them both accountable for pandemic' (The Hill, 17 Mart 2020) <https://thehill.com/opinion/international/487851-china-and-the-whos-chief-hold-them-bothaccountable-for-pandemic> Erişim Tarihi 28 Mayıs 2020.

139 Jeremy Page, Betsy McKay, 'The World Health Organization Draws Flak for Coronavirus Response' (Wall Street Journal, 12 Şubat 2020) <https://www.wsj.com/articles/the-world-health-organization-draws-flak-for-coronavirus-response$11581525207>$ Erişim Tarihi 28 Mayıs 2020.

140 DSÖ’nün Çin ile olan ilişkisinin bütçe odaklı düşünülmemesi gerektiği, zira Çin'in DSÖ’ye olan katkısının kayda değer miktarda olmadığını da vurgulayanlar olmuştur, bkz 'Fighting the Coronavirus Pandemic: China's Influence at the World Health Organization' (n 132).

141 Lee (n 19) 49.

142 The White House, 18 Mayıs $2020<$ https://www.whitehouse.gov/wp-content/uploads/2020/05/Tedros-Letter.pdf> Erişim Tarihi 28 Mayis 2020.

${ }_{143}$ Lawrence Gostin vd, ‘The Normative Authority of the World Health Organization’ (2015) 129(7) Public Health 854, 861.
} 
yükümlülüklerine uymamaları ve işbirliğine yanaşmamaları ihtimallerinde DSÖ'den olabilecek en büyük beklenti, devletdışı aktörlerden gelen bilgileri iyi takip etmesi olabilecektir. Ancak hangi devletdışı aktörden gelen ve hangi nitelikteki bilgilerin dikkate alınması gerektiğine dair ikincil bir sorun da göz ardı edilmemeli ve DSÖ'nün hiçbir filtre uygulamaksızın her türlü uyarıya aynı önemi vermesi beklenmemelidir. ${ }^{144}$ Kaldı ki devletdışı aktörlerden gelen bilgi akışının devletler tarafından bastırılması yahut manipüle edilmesi oldukça mümkündür. Bu bakımdan, isabetli bilgi paylaşımında bulunan ancak kendi ülkelerinde devletin baskısına maruz kalabilecek devletdışı aktörlerin korunması için de azami özen gösterilmeli ve 2005 tarihli UST’nin 9. maddesinde yer alan, DSÖ'nün devletdışı aktörlerden gelen bilgilerin gizliliğini koruyabilme yetkisi dikkatle kullanılmalıdır. Nihayetinde, yine mesele devletlerin tutumu ile çok yakından ilişkilidir. Nitekim uluslararası sağlık hukuku ve bilhassa küresel salgın yönetimi hususunda uluslararası hukukun genel bir ilkesi olan "iyi niyet ilkesinin" oldukça öne çıtı̆̆ 1 belirtilmiştir. ${ }^{145}$ Nihayetinde, COVID-19 salgınında, 2005 tarihli UST'nin 21. yüzyılın başında sağlık alanında uluslararası işbirliğine getirdiği çerçeveye rağmen Çin'in DSÖ'yü zamanında bilgilendirmemesi esas olarak DSÖ'nün değil, Çin'in sorumluluğunun tartışılmasını gerektirmektedir. ${ }^{146}$ Nitekim DSÖ Acil Durum Komitesi'nin bazı üyeleri de Çin'in salgının ilk aşamasında yavaş bilgi sağlamasından yakınmıştır. ${ }^{147}$

Ayrıca ifade etmek gerekir ki salgın gibi hızla etki alanı genişleyen krizlerde ilk aşamada yaşatılan bir gecikme, daha sonraki adımların gecikmesine de doğal olarak zemin hazırlamaktadır. DSÖ’nün "uluslararası düzeyde halk sağlığı acil durumu" ve salgın ilânlarında gecikmesi bu şekilde izah edilebilir. ${ }^{148}$ Ancak her bir kararın gecikmeli olarak verilip verilmediği kendi müstakil koşulları bağlamında değerlendirilerek kesin bir sonuca ulaşlabilecektir. Örneğin, kanaatimize göre, "uluslararası düzeyde halk sağlığı acil durumu" ilânının gecikmesi, Çin'den gelen yavaş ve yetersiz bilgi akışıyla açıklanabilecekken, salgın ilânının gecikmesini sadece bu sebebe bağlamak güçtür.

COVID-19 salgınından çıkarılması gereken derslerden biri, her türlü gecikmenin ve yetersizliğin faturasının DSÖ'ye çıkarılmasından ziyade, devletlerin olası bir salgın durumunda iyi niyet ilkesine uygun davrandığı ve hızlı bir şekilde masanın

44 Bazı devletdışı aktörlerin DSÖ ile çok yakın bir ilişki içerisinde olduğu gerçeği de göz ardı edilmemesi gereken bir husustur. DSÖ’ye ciddi bir finansman katkısında bulunan Bill\&Melinda Gates Foundation bu durumun en iyi örneğidir, bkz Natalie Huet, Carmen Paun 'Meet the world's most powerful doctor: Bill Gates' (Politico, 4 May1s 2017) <https://www.politico.eu/ article/bill-gates-who-most-powerful-doctor/> Erişim Tarihi 19 Mayıs 2020.

145 Pedro Villarreal, 'The 2019-2020 novel coronavirus outbreak and the importance of good faith for international law' (Voelkerrechtsblog, 28 Ocak 2020) <https://voelkerrechtsblog.org/the-2019-2020-novel-coronavirus-outbreak-and-theimportance-of-good-faith-for-international-law/> Erişim Tarihi 28 Nisan 2020.

146 Lee (n 19) 48

147 Primrose Riordan, Sue-Lin Wong, 'WHO Expert Says China Too Slow to Report Coronavirus Cases' (Financial Times, 5 Şubat 2020) <https://www.ft.com/content/8ede7e92-4749-1lea-aeb3-955839 e06441> Erişim Tarihi 28 Mayıs 2020.

148 Anderson vd (n 13) 17. 
etrafında buluşup çok taraflı bir istişare ve eylem mekanizmasının gerekliliği olmalıdır. Böyle bir ders çıkarıldıktan sonra, bu tip bir mekanizmaya DSÖ rahatlıkla koordinatörlük yapabileceği gibi, bu tercih edilmezse DSÖ bu mekanizmada salt bir katılımcı olarak da yer alabilir. ${ }^{199}$ Kilit husus, devletlerin bu yönde bir iradeyi ortaya koymaları ve işbirliği eksiğinin salgının sonuçlarını çok daha vahim hâle getirdiğini takdir etmeleridir. ${ }^{150}$ Öte yandan, devletler yukarıda belirtilen şekilde toplu bir irade ortaya koyabilirlerse, 2005 tarihli UST'nin DSÖ'ye daha geniş izleme, değerlendirme ve düzenlemelere uyumu arttırma yetkilerini verecek bir şekilde güncellenmesi de tartışılabilir. ${ }^{151}$ Mevcut durumda hem DSÖ'nün kendi kurumsal yetkisi ve kapasitesi bu işlevleri sağlamak için yeterli değildir hem de 2005 tarihli UST'ye taraf devletlerin birçoğu Tüzük çerçevesindeki temel bazı yükümlülüklerini yerine getirmekten kaçınabilmektedir. ${ }^{152}$ Böylece, öngörülen sistemin işleyişinde yapısal sorunlar ortaya çıkmaktadır. ${ }^{153}$ Mevcut uygulama oldukça ağırlıklı bir şekilde devletlerin kendi kendilerini değerlendirmelerine bağlıdır. Dolayısıyla, bu konuda devletleri zorlayıcı bir mekanizma yoktur. 2005 tarihli UST hükümlerinin ihlâl edilmesi durumunda devletlere uygulanacak belirgin bir yaptırım mekanizmasının oluşturulmaması ve öngörülen uyuş̧mazlık çözüm mekanizmasının ihtiyari niteliği ${ }^{154}$ tüzüğün etkinliğini azaltmaktadır. ${ }^{155}$

DSÖ’nün etkinliğinin sağlanması için yapılan önerilerden biri de örgütün devlet merkezci bir yaklaşımdan biraz uzaklaşması ve DSM'nin devlet yetkililerine ek olarak sivil topluma ve genel olarak devletdışı aktörlere sağladığı katılım imkânının arttırılmasıdır. ${ }^{156}$ Böylece, devletlerin üzerindeki sivil toplum denetiminin ve baskısının uluslararası bir zeminde arttırılmasının olanaklı olacağı düşünülmektedir. Ayrıca DSÖ'nün uluslararası koordinasyon görevini daha etkili bir şekilde gerçekleştireceği umulmaktadır. ${ }^{157}$

DSÖ'nün hâlihazırda sahip olduğu kural koyma (normatif) yetkilerini daha çok kullanma yönünde bir yaklaşım geliştirmesi de çözüm önerileri arasında yer alabilir. ${ }^{158}$ DSÖ'nün bu yetkiyi kullanma konusunda çekingen olmasını tarihsel

\footnotetext{
149 'COVID-19 and International Law: What went wrong and what can we learn from it?' (n 83) 8.

150 2014-2016 yılları arasındaki Ebola salgınındaki işbirliği eksikliğinin sonuçlarına dair bkz David Fidler, 'The Ebola Outbreak and the Future of Global Health Security' (2015) 385, The Lancet 1888.

151 'COVID-19 and International Law: What went wrong and what can we learn from it?' (n 83) 10.

152 Lee (n 19) 50; Deniz Baran, 'Covid-19 Salgını ve Çin'in Uluslararası Hukuk Açısından Sorumluluğu' (GPoT Center, Nisan 2020 ) <http://www.gpotcenter.org/sites/default/files/opinion/Covid-19\%20Salgini\%20ve\%20Cin'in\%20Uluslararasi\%20 Hukuk\%20Acisindan\%20Sorumlulugu.pdf $>$ Erişim Tarihi 17 Mayıs 2020.

153 Ibid 48.

154 'Uluslararası Sağlık Tüzüğü' (n 72) m 56.

155 Steven Hoffman, 'Making The International Health Regulations Matter: Promoting Compliance Through Effective Dispute Resolution' in Simon Rushton ve Jeremy Youde (eds), Routledge Handbook of Global Health Security (Routledge 2015) 239.

156 Fidler, 'The Future of the World Health Organization: What Role for International Law?' (n 37) 1118-1122.

157 Lee (n 19) 52.

158 Gostin, ‘A Proposal for Framework Convention on Global Health’ (n 55) 996.
} 
olarak hakl1 gösteren olgular yok değildir. DSÖ’nün teknik düzenlemelerin biraz dışına taşan adımları birçok kez politik meşruiyet tartışmalarına sebep olmuş, yapılan girişimler hızla siyasallaştırılabilmiştir. ${ }^{159}$ Öyle ki DSÖ birçok uluslararası örgütte olmayan nitelikteki kural koyma yetkisine rağmen günümüze kadar sadece bir genel uluslararası sözleşme (Tütün Kontrolüne ilişkin Çerçeve Sözleşme) ${ }^{160}$ ve iki düzenleme (Uluslararası Sağlık Tüzüğü ve Hastalıklar ile Ölüm Sebeplerine ilişkin İsimlendirme Tüzüğ ̈̈ ${ }^{161}$ ) yapmıştır. Ancak COVID-19 salgınının küresel ölçekteki sarsıcıllğı ile birlikte, daha etkili bir küresel sağlık yönetimi için kural koyma noktasında daha çok inisiyatif alan bir DSÖ ihtiyacı öne çıkmaktadır. Örneğin, temel bir insan hakkı olarak sağlık hakkı meselesi DSÖ'nün doğrudan faaliyet alanı dahilinde olmasına rağmen bu alanda genelgeçer normları bu zamana kadar sadece BM Ekonomik, Kültürel ve Sosyal Haklar Komitesi geliştirmiş ${ }^{162}$ ve 1977 yılındaki "Herkes için Sağlık"163 gibi bağlayıcı kurallar üretmeyen bazı programlar dışında DSÖ'den bu meseleye anlamlı bir katkı gelmemiştir.

DSÖ'nün sıkça eleştirildiği noktalardan biri de, salgın dönemlerinde önemli bir rol oynayan Acil Durum Komitesi'nin aldığı kararların yeterince şeffaf olmayışıdır. Acil Durum Komitesi'nin yaptığı toplantıların notları yayımlanmamaktadır. Ayrıca Komite'nin kararları her zaman son derece kısa ve herhangi bir muhalif görüşe yer verilmeksizin tek bir kanaatin belirtilmesi şeklinde kamuoyuna açıklanmaktadır. Dolayısıyla, Komite içerisindeki tartışmalar ve farklı fikirler kamuoyuna yansımamaktadır. Böyle bir usul yerine, verilen kararların daha detaylı olması ve var ise farklı fikirlere de en azından muhalif görüş şeklinde yer verilmesi gerektiği belirtilmektedir. ${ }^{164}$

Üzerinde durulması gereken bir başka komite de İnceleme Komitesi'dir. Mevcut hukuki çerçevede, İnceleme Komitesi'nin raporları DSÖ organlarının veya yetkililerinin görevi suiistimal ettiğine dair kesin bulgulara ulaşsa dahi, bunların herhangi bir bağlayıcıllğı yoktur. Bu durum, İnceleme Komitesi'nin denetim gücünü ciddi ölçüde etkisizleştirmektedir. İnceleme Komitesi'nin oluşturulması ve Komite üyelerinin seçilmesi sürecinde DSÖ Genel Direktörü'nün geniş yetkiye sahip olması da Komite'nin bağımsızlığını ve ne denli etkili bir denetim yapabileceğini şüpheye

\footnotetext{
159 Sudeepa Abeysinghe, Pandemics, Science and Policy. H1N1 and the World Health Organization (Palgrave Macmillan 2015) 133-171; Marcos Cueto, 'The Origins of Primary Health Care and Selective Primary Health Care' (2004) 94 American Journal of Public Health, 1864, 1864-1866; Steinbrück-Platise (n 63) 90-92.

160 'Who Framework Convention On Tobacco Control' (WHO, 2003) <https://apps.who.int/iris/bitstream/ handle/10665/42811/9241591013.pdf?sequence=1> Erişim Tarihi 29 Mayıs 2020; detaylı bir inceleme için bkz Gostin, Global Health Law (n 21) 205-242.

161 'Regulations Regarding Nomenclature' $(W H O)<$ https://www.who.int/classifications/icd/docs/en/NOMREGS.pdf $>$ Erişim Tarihi 29 Mayıs 2020.

162 BM Ekonomik ve Sosyal Konsey, 'General Comment 14: The right to the highest attainable standard of health (2000) (E/C.12/2000/4).

163 Dünya Sağlık Örgütü, Resolution WHA 30.43.

164 Bogdandy ve Villarreal, 'Critical Features of International Authority in Pandemic Response: The WHO in the COVID-19 Crisis, Human Rights and the Changing World Order' (n 94) 11-12.
} 
düşürmektedir. DSÖ'nün faaliyetleri üzerinde etkili bir denetim mekanizmasının tesis edilmesi için, İnceleme Komitesi'ni daha bağımsızlaştıracak ve yetkili hâle getirecek bazı değişiklikler yapılabilir. Ayrıca, hem Acil Durum hem de İnceleme Komitesi'ne seçilecek isimlerin yer aldığ DSÖ uzman listesinin ${ }^{165}$ adil bir coğrafi temsil sağlamadığı yönündeki eleştiriler dikkate alınmalı ${ }^{166}$ ve bu liste daha kapsayıcı hâle getirilmelidir.

DSÖ kendisinin sağlık izleme, raporlama ve veri depolama mekanizmalarını her zaman modern teknoloji ile uyumlu hâle getirmeli, böylece en etkili takip yollarına sahip olmalıdır. Ancak bir diğer önemli husus, 2005 tarihli UST'nin temelinde taraf devletlerin gözetim ve tespit kapasitelerini arttırmaları olduğu hâlde, gelişmekte olan veya az gelişmiş devletlerin bunu sağlayacak kapasiteden yoksun olabilmesi karşısında bu devletlere yardım yükümlülüğünü getiren herhangi bir bağlayıcı hükmün 2005 tarihli UST'de yer almamasıdır. COVID-19 krizi Çin gibi gelişmiş bir devlette ortaya çıktığı ve az gelişmiş devletlerin yoğun olarak yer aldığı Sahra altı Afrika gibi bölgelere geç ulaştığı için bu anlamda şimdilik çok büyük bir kriz yaşanmasa da gelecekte ortaya çıkabilecek başkaca bulaşıcı hastalıkların gözetimi ve erken tespiti için, tüm devletlerin asgari düzeyde kapasite geliştirmesinin yolları üzerinde düşünülmelidir. ${ }^{167} \mathrm{Bu}$ minvalde, kalkınmış devletlerin ve güçlü özel sektör aktörlerinin gelişmekte olan veya en azından az gelişmiş devletlere ulusal sağlik sistemlerini geliştirmeleri için teknik ve finansal yardımda bulunması meselesi gündeme getirilmelidir. ${ }^{168}$ Neredeyse hiçbir az gelişmiş devletin salgınların yıkıcı etkilerinin yükünü taşıyacak sağlık altyapısı mevcut değildir. Bu devletlere yardım edilmesi ve bunların asgari düzeyde bir sağlik altyapısına kavuşturulması sadece bir sosyal adalet meselesi olmayıp aynı zamanda son derece küreselleşmiş bir dünyada kamusal sağlığın küresel ölçekte korunması için bir ihtiyaçtır. Zira uluslararası toplumun ciddi bir kısmını oluşturan bu devletlerin kendi ülkelerinde bulaşıcı hastalıkları yeterli bir şekilde takip ve kontrol etme kapasitesinden yoksun olması tüm diğer devletleri de riske atmaktadır. Yolsuzluk, bürokratik engeller ve teknik beceri yoksunluğu gibi olası sorunları da hesaba katarak ${ }^{169}$ hazırlanacak bir küresel çapta sağlık altyapısını geliştirme plânı salgınların ortaya çıkardığı tehlikelerin çok daha azaltılması yolunda muazzam bir etki sağlayacaktır. ${ }^{170}$ Ancak tarihsel deneyimin bize gösterdiği üzere, uluslararası toplumun böyle bir yönelime girmesi bazı

\footnotetext{
165 'Uluslararası Sağlık Tüzüğü’ (n 72) m 47.

166 Dünya Sağlik Örgütü, 'Annual Report on the Implementation of the International Health Regulations, Report by the Director-General' (2019) (A72/8) para 26.

167 Fidler ve Gostin (n 74) 88.

168 Gostin, 'World Health Law: Toward a New Conception of Global Health Governance for the 21st Century' (n 39 ) 420.

169 Ibid 422; David Bishop, 'Lessons from SARS: Why the WHO Must Provide Greater Economic Incentives for Countries to Comply with International Health Regulations' (2005) 36 Geo J Int'l L $1173,1211-1212$.

170 Kimileri bu ihtiyacı "sağlık alanında bir Marshall Plânı"nın gerekliliği olarak nitelemektedir, Gostin, 'A Proposal for Framework Convention on Global Health' (n 55) 989- 990.
} 
devletlerin söz konusu meseleye ilişkin küresel öncü rolünü üstlenmesiyle mümkün olmaktadır. İkinci Dünya Savaşı'nın bitişinden bu yana ABD'nin uluslararası sağlık hukuku ve salgınlarla mücadele konusunda böyle bir rol oynadığını, dolayısıyla mevcut küresel sağlık yönetiminin inşasının ve muhafazasının zeminini hazırladığını söylemek mümkündür. ${ }^{171}$ Ayrıca dönem dönem güçlenen sosyalist blok devletlerinin, belli uluslararası sağlık hukuku standartlarının oluşturulması için etkili bir lobi yapabilmesi söz konusu olmuştur. ${ }^{172}$ Fakat günümüzde bu şekilde öncü rol üstlenecek bir güç merkezinin olmaması kaygı vericidir. Böyle öncü aktörlerin yokluğunda, az gelişmiş devletlere yardım yapılması bir yana, aşı çalışmalarının tekelleştirilmesine yönelik hamleler veya tıbbi malzemelere el koyma uygulamaları gibi durumlar sıklıkla gündeme gelmektedir. ${ }^{173}$

Yine COVID-19 salgınında ortaya çıkmıştır ki DSÖ ve salgının birincil olarak etkilediği uluslararası ticaret ve ulaşım gibi diğer alanlardaki temel küresel yönetim örgütleri tarafından salgın sırasında atılan adımların birbirine uyumlu olması gerekmektedir. ${ }^{174}$ Bu bakımdan, DSÖ’nün Uluslararası Sivil Havacılık Örgütü (ICAO) yahut Dünya Ticaret Örgütü (DTÖ) gibi örgütlerle resmi veya yarı resmi, kriz masası benzeri ortak bir istişare mekanizması kurması faydalı olacaktır. Örneğin, DTÖ'nün ortaya koyduğu uluslararası ticaret hukuku anlaşmalarının üzerinde DSÖ'nün ortaya koyduğu uluslararası sağlık hukuku rejiminin pek bir etkisi görülememekte ve bu durum ister istemez bazı kopukluklara yol açmaktadır. ${ }^{175} 2005$ tarihli UST'nin hazırlık çalışmalarının (travaux préparatoires) ${ }^{176}$ arşivlenmemiş olması da söz konusu kopuklukları gidermek için Tüzük hükümlerinin yorumlanmasına başvurulmasını zorlaştırmaktadır, zira mevcut durum büyük yorum farklarının ortaya çıkmasına zemin hazırlamaktadır. ${ }^{177}$ Söz konusu kopuklukları gidermenin en iyi yolu, farklı uluslararası hukuk rejimlerinin temel küresel yönetim mercii konumundaki örgütlerin doğrudan istişarede ve işbirliğinde bulunması olacaktır.

Son olarak ifade etmek gerekir ki DSM'nin 19 Mayıs 2020'de yaptığı toplantıda DSÖ’nün COVID-19 sürecini yönetirken attığı adımlara ilişkin bağımsız bir soruşturma kararı alması, DSÖ’ye yönelik yukarıdaki eleştirilerin detaylı bir

\footnotetext{
171 Lee (n 19) 41.

172 Genel olarak bkz Anne-Emanuelle Birn, Nikolai Krementsov, 'Socialising' primary care? The Soviet Union, WHO and the 1978 Alma-Ata Conference' (2018) 3(3) BMJ Global Health 1.

173 Rana Moustafa Fouad, 'The Legal Duty to Cooperate amid COVID-19: A Missed Opportunity?' (EJIL Talk, 22 Nisan 2020) $<$ https://www.ejiltalk.org/the-legal-duty-to-cooperate-amid-covid-19-a-missed-opportunity> Erişim Tarihi 28 Mayıs 2020.

174 'The Collapse of Global Cooperation under the WHO International Health Regulations at the Outset of COVID-19: Sculpting the Future of Global Health Governance' (ASIL, 5 Haziran 2020) < asil.org/insights/volume/24/issue/15/collapseglobal-cooperation-under-who-international-health-regulations> Erişim Tarihi 28 Mayıs 2020, s 4-5.

175 Gostin, 'A Proposal for Framework Convention on Global Health' (n 55) 996-997.

176 'Travaux préparatoires'ın uluslararası anlaşmalardaki rolü için bkz Herbert Briggs, 'The Travaux Préparatoires of the Vienna Convention on the Law of Treaties' (1971) 65 American Journal of International Law 705.

177 Kamradt-Scott (n 69) 267.
} 
değerlendirmesinin yapılması imkanını sunacaktır. ${ }^{178} \mathrm{Bu}$ soruşturmanın kapsamlı ve objektif bir şekilde yapılması durumunda, DSÖ’nün uluslararası salgın yönetiminde ne tür yapısal değişikliklere ihtiyaç duyduğunu daha isabetli bir şekilde tespit etmek de mümkün olacaktır.

\section{Sağlık Hukukunun Ötesinde Uluslararası Hukuk ve COVID-19}

Şüphesiz ki COVID-19 meselesinin uluslararası hukuku ilgilendirdiği tek alan uluslararası sağlık hukuku ve DSÖ sistemi değildir. Kamu sağlığının hayatın birçok yönünü etkileyen niteliğinden ötürü, uluslararası hukukun her biri kendi içerisinde ayrı bir teleolojiye ve mekanizmalara sahip farklı alt dalları COVID-19 tarzı salgınlardan etkilenmektedir. ${ }^{179}$ Nitekim DSÖ rejiminin ve bilhassa Uluslararası Sağlık Tüzüğü'nün on yıllar içerisinde geçirdiği dönüşüm de uluslararası sağlık hukuku ile tüm temel küresel yönetim mekanizmalarının yakın bağına işaret etmektedir. Uluslararası havacıllk hukukundan deniz hukukuna, insancıl hukuktan kalkınmaya ve yatırım hukukuna kadar birçok alan bu bağlamda sayılabilir. ${ }^{180}$ Ancak tüm bu alanların müstakil bir şekilde değerlendirilmesi oldukça geniş bir yer tutacağı için, şu an mevcut salgın çerçevesinde siklıkla gündeme gelmesi ve doğrudan etkilenmesi itibariyle en çok öne çıkan üç alanı detaylı bir şekilde ele almayı isabetli bulmaktayız. Bunlar; uluslararası insan hakları hukuku, uluslararası ticaret hukuku ve uluslararası kolektif güvenlik alanlarıdır.

\section{A. Uluslararası İnsan Hakları Hukuku ve COVID-19}

COVID-19 salgınına karşı dünya çapında alınan önlemler, bu tip küresel salgınların insan haklarını ne denli kapsamlı bir şekilde sınırlayabileceğini göstermiştir. DSÖ, dünyanın dört bir tarafındaki devletlere kitlesel karantina önlemini kuvvetli bir şekilde tavsiye etmiş, ${ }^{181}$ en gelişkin uluslararası insan hakları hukuku araçlarına sahip olan Avrupa Konseyi'ne üye birçok devlet insan haklarına yönelik kısıtlayıcı veya askıya alıcı önlemleri meşrulaştıracak istisna hükümlere (derogasyon-derogation) ${ }^{182}$ başvurduklarına yönelik bildirimlerini ivedi bir şekilde Konsey'e iletmiştir. ${ }^{183}$ Zira kamu sağlığının ve bilhassa bireylerin yaşam ve sağlık haklarının korunması da hem bir hak hem de devletlerin pozitif bir yükümlülügüdür. Dolayısıyla, mevcut salgın bir yandan birçok siyasi, medeni, ekonomik, sosyal ve kültürel hakkın

\footnotetext{
178 Dünya Sağlık Meclisi, 73. Toplantı (Sanal Ortamda).

179 Pedro A Villarreal, 'Public International Law and Human Health: Bridging Conceptual Gaps Through Governance' (2018) 61 German Yearbook of International Law 45,45-50.

180 Uluslararası hukukun farklı alanlarının küresel yönetim bağlamındaki etkileşimi için bkz Cüneyt Yüksel (n 10) 27-28.

181 DSÖ, 'Considerations for quarantine of individuals in the context of containment for coronavirus disease (COVID-19)' (19 Mart 2020) 2.

182 Derogasyon kavramına ilişkin genel bir değerlendirme için bkz Audrey Lebret, COVID-19 pandemic and derogation to human rights, Journal of Law and the Biosciences, lsaa015.

183 Moldova'dan gelen ilk bildirim için bkz 'Notification of 18 March 2020'<https://rm.coe.int/09000016809cf9a2.> Erişim Tarihi 2 Haziran 2020.
} 
özgürce kullanılmasını olumsuz etkilemekte, öte yandan ise söz konusu olumsuz etkileri doğuran kısıtlamalar sağlık ve yaşam haklarının bir tezahürü olarak ortaya çıkmaktadır. Elbette devletlerin sağlık ve yaşam haklarını koruma yükümlülüğünü yerine getirmesi ile seyahat özgürlüğü, kişi hürriyeti, ibadet hakkı, çalışma hakkı vb. diğer hakları koruma yükümlülüğ̈̈ arasındaki hassas dengeyi kurmak oldukça zorlu bir iştir. Zira günümüz uluslararası insan hakları hukukunda teorik olarak siyasi, medeni, ekonomik, sosyal ve kültürel haklar arasında bir hiyerarşinin var olmadığı kabul edilmektedir. ${ }^{184}$ Ancak ne kadar zorlu bir iş olursa olsun, bu dengenin kurulması geniş halk kitlelerinin, bilhassa da daha kırılgan durumdaki kesimlerin, belli haklarının ciddi bir şekilde ihlâl edilmesi sonucunu doğurabilmektedir. Salgınla mücadele için önlemler alınırken hiçbir kesimin ve bireyin göz ardı edilmemesi son derece mühimdir. ${ }^{185}$

Uluslararası insan hakları hukukunun temel kaynaklarından biri olan 1966 tarihli BM Medeni ve Siyasi Haklar Sözleşmesi'nin 4. maddesinde ulusun yaşamını tehdit eden kamusal acil durumlarda devletlerin bazı insan hakları yükümlülüklerini yerine getirmeyi durdurabilecekleri düzenlenmektedir. Ayrıca bu tip önlemleri devreye sokan devletlerin, söz konusu önlemlerin mahiyetini ve gerekçelerini açıklayan bir bildirimi gecikmeksizin BM Genel Sekreterliği’ne yapması gerektiği de aynı maddenin son fikrasında belirtilmektedir. Nitekim, BM İnsan Hakları Komitesi 24 Nisan 2020'de yayımladığı bir açıklama ile salgınla mücadele kapsamında insan haklarını kısıtlayıcı önlemler almak durumunda kalan devletlerin BM Genel Sekreterliği'ne ivedi bir şekilde bildirimde bulunması gerekliliğini hatırlatmıştır. ${ }^{186}$ Yine 1966 tarihli BM Ekonomik, Sosyal ve Kültürel Haklar Sözleşmesi'nin 4. maddesinde bu Sözleşme'de ihdas edilen hakların ancak her bir hakkın doğasına uygun bir şekilde ve demokratik bir toplumda genel refahın sağlanması için kısıtlanabileceği (sınırlandırma-limitation) yönünde genel bir düzenleme mevcuttur. Görülebileceği üzere, Medeni ve Siyasi Haklar Sözleşmesi’nde düzenlenen, devletlerin bazı insan hakları yükümlülüklerini yerine getirmeyi durdurabileceklerine ilişkin hüküm ancak ve ancak olağanüstü şartlarda, zaman bakımından sınırlı olacak şekilde ve belli hakların kullanımının sadece kısıtlanmasını değil, gerekirse tamamen durdurulmasını da kapsayacak mahiyettedir. Avrupa İnsan Hakları Sözleşmesi (AİHS) ${ }^{187}$ ve Amerikan İnsan Hakları Sözleşmesi'nde ${ }^{188}$ de benzer bir hüküm yer almaktadır. Ancak Ekonomik, Sosyal ve Kültürel Haklar Sözleşmesi’nin 4. maddesi olağanüstü durumlara bağlı olmayan, dolayısıyla sürekli geçerli olan ve belli hakların kullanımının durdurulmasını

\footnotetext{
184 BM İnsan Hakları Yüksek Komiserliği, 'Key concepts on ESCRs - Are economic, social and cultural rights fundamentally different from civil and political rights?' $<$ https://www.ohchr.org/EN/Issues/ESCR/Pages/ AreESCRfundamentallydifferentfromcivilandpoliticalrights.aspx> Erişim Tarihi 3 Haziran 2020.

185 'BM Ekonomik ve Sosyal Konsey Açıklaması' (17 Nisan 2020) (E/C.12/2020/1).

186 BM İnsan Hakları Komitesi, 'Statement on derogations from the Covenant in connection with the COVID-19 pandemic' (24 Nisan 2020) (CCPR/C/128/2).

187 Avrupa İnsan Hakları Sözleşmesi (1952) (AİHS) m 15, 18.

188 Amerikan İnsan Hakları Sözleşmesi (1948) m 27.
} 
değil, sadece kısıtlanabilmesini öngören bir içeriğe sahip olması itibariyle oldukça farklıdır. İnsan Haklarına İlişkin Arap Şartı'ndaki sınırlama hükmü, ${ }^{189}$ Ekonomik, Sosyal ve Kültürel Haklar Sözleşmesi'nin 4. maddesine benzemektedir. Her ne kadar COVID-19'un bir olağanüstü durum teşkil etmesi sebebiyle, Medeni ve Siyasi Haklar Sözleşmesi, AİHS ve Amerikan İnsan Hakları Sözleşmesi'nde yer alan istisna hükümleri öncelikli olarak gündeme gelse de yukarıda belirtilen diğer uluslararası sözleşmelerdeki istisna hükümler de göz ardı edilmemelidir.

Medeni ve Siyasi Haklar Sözleşmesi'nin Sınırlandırma ve Derogasyon Hükümlerine İlişkin Siracusa İlkeleri (kısaca Siracusa İlkeleri), bu Sözleşme'de ihdas edilen hakların COVID-19 salgını benzeri durumlarda hangi şartlar altında kısıtlanabileceğini detaylı bir şekilde ortaya koymaktadır. ${ }^{190}$ Buna göre, alınacak kısıtlayıcı önlemlerin zorunlu bir kamusal veya toplumsal gereksinime yönelik olması, meşru bir amacı gütmesi, orantılı olması ve hedeflenen amaca ulaşılması için gerekli olan kısıtlama seviyesinden daha sıkı olmaması gereklidir. ${ }^{191}$ Ayrıca, Siracusa İlkeleri'nin 25. ve 26. paragrafları özel olarak kamusal sağlığı ilgilendiren durumlara ayrılmış olup söz konusu durumlarda diğer belli hakların kısıtlanabileceği ancak bu kısıtlamaların DSÖ düzenlemelerine uygun olması gerektiği belirtilmiştir. Öte yandan, doğrudan Medeni ve Siyasi Haklar Sözleşmesi'nde öngörülen başkaca şartlar da mevcuttur. Önlemlerin hiçbir şekilde ayrımcıllı yapılmadan uygulanmas1, ${ }^{192}$ insanlık onuruna aykırı nitelikte olmamas $1{ }^{193}$ ve işbu Sözleşme'nin 6., 7., 8. (1. ve 2. paragraflar), 11., 15., 16. ve 18. maddelerindeki hakların hiçbir şekilde derogasyona maruz kalmaması gerekliliği bunlar arasında sayılabilir. BM İnsan Hakları Komitesi'nin Medeni ve Siyasi Haklar Sözleşmesi'nin hükümlerine 1şık tutmak için ortaya koyduğu Genel Yorumlar arasından derogasyon hükmüne ilişkin olan 29 Numaralı Genel Yorum'da seyahat hakkı, toplanma hakkı gibi bazı hakların yanı sıra çok olağanüstü durumlarda kişi hürriyetinin dahi kısıtlanabileceği ancak bu hakka ilişkin kısıtlamaların hukukiliğinin bir yargı kararı ile tasdik edilmesi gerekliliği belirtilmiştir. ${ }^{194}$

Derogasyon veya sinırlandırma uygulamalarında temel olarak bilimsel ve tıbbi verilerin esas alınması gerekliliği ayrıca ifade edilmelidir. Yukarıda belirtilen insan hakları sözleşmelerinden ziyade 2005 tarihli UST'de dile getirilen ${ }^{195}$ bu şart şüphesiz ki insan hakları hukukuyla doğrudan ilgilidir. Esasında, 2005 tarihli

\footnotetext{
189 İnsan Haklarına ilişkin Arap Şartı (1945) m 4.

190 Medeni ve Siyasi Haklar Sözleşmesi’nin Sınırlandırma ve Derogasyon Hükümlerine İlişkin Siracusa İlkeleri (UN Doc. E/ CN.4/1985/4) (1985).

191 Ibid para 1(10).

192 Medeni ve Siyasi Haklar Sözleşmesi (1966) m 2, 26.

193 Ibid $\mathrm{m} 10$.

194 BM İnsan Hakları Komitesi, 'CCPR General Comment No. 29: Article 4: Derogations during a State of Emergency' (31 Ağustos 2001) (CCPR/C/21/Rev.1/Add.11).

195 ‘Uluslararası Sağlık Tüzüğü' (n 72) m 43(b).
} 
UST'nin daha 1. maddeden başlayarak ${ }^{196}$ birçok hükmünün insan hakları hukuku düzenlemelerini doğrudan ihtiva ettiğini belirtmek gerekir. ${ }^{197}$ Ayrıca 2005 tarihli UST ile genel uluslararası insan hakları hukuku arasındaki bir diğer bağ da genel insan hakları hukuku kaynaklarının tüzüğün bazı hükümlerinin yorumlanmasında ve uygulanmasında doğrudan etkili olmasıdır. ${ }^{198}$ Örneğin, 2005 tarihli UST'nin 3. ve 32. maddelerinde yer alan "insan haklarına, insanlık onuruna ve temel hürriyetlere saygl" yükümlülüklerine ilişkin herhangi bir detay verilmemiş olup bu açık uçlu ifadelerin yorumlanmasında genel insan hakları hukuku kaynaklarının devreye girmesine açık kapı bırakılmıştır.

Türkiye'nin de tarafı olduğu AİHS, derogasyona yönelik detaylı hükümler içermektedir. Nitekim Avrupa Konseyi, Nisan 2020'de üye devletlerin COVID-19 salgınına yönelik alacağı kısıtlayıcı önlemlerde dikkate alınması gereken hukuki çerçeveyi hatırlatmak adına bir rehber yayımlayarak tüm bu hükümleri detaylı bir şekilde ortaya koymuştur. ${ }^{199}$ Öncelikli olarak, savaş sırasındaki hukuka uygun eylemler haricinde yaşam hakkının, işkence ve insanlık dışı ya da aşağılayıcı muamele veya cezalandırma yasağının, kölelik ve zorla çalıştırma yasağının ve kanunsuz ceza olmaz ilkesinin hiçbir şekilde derogasyona tabi olmayacağ 1 düzenlenmektedir. ${ }^{200}$ Derogasyonun ancak savaş veya ulusun varlığını tehdit eden başka bir genel tehlike hâlinde meşru olacağ 1 ve derogasyon bağlamında alınan önlemlerin ve gerekçelerinin Avrupa Konseyi Genel Sekreteri'ne bildirilmesi gerektiği belirtilmektedir. ${ }^{201}$

AİHS kaynaklı uyuşmazlıklara bakan Avrupa İnsan Hakları Mahkemesi (AİHM) de verdiği birçok kararla yukarıda anılan hükümlerin çerçevesini detaylı bir şekilde çizmiştir. Örneğin, AİHM'in içtihatları savaş dışında derogasyonu mümkün kılacak diğer kamusal acil durumlarını tanımlayarak bu ucu açık kavrama bir açıklık getirmiştir. ${ }^{202}$ Derogasyonun bir ülkede sadece resmi olarak olağanüstü hâl ve benzeri bir durum ilân edilmesiyle doğrudan meşrulaşmayacağ 1 , keyfi kullanımı ve suiistimali engelleyecek bir ulusal mevzuatın esas alınması ve devletlerin demokratik topluma yaraşan değerleri korumak için elinden gelen her türlü çabayı göstermesi gerektiği AİHM tarafından belirtilmiştir. ${ }^{203}$ Bu noktada, Avrupa Konseyi’nin danışma organı statüsündeki Venedik Komisyonu'nun altını çizdiği "olağanüstü hâllerde

\footnotetext{
196 1. maddede yer alan tanımlar izolasyon ve karantina gibi son derece kısıtlayıcı uygulamalarının hangi durumlarda yapılması gerektiğinin çerçevesini de düzenlemektedir, detaylı bir inceleme için bkz A Wilder-Smith, David Freedman, 'Isolation, Quarantine, Social Distancing and Community Containment: Pivotal Role For Old-Style Public Health Measures in The Novel Coronavirus (2019-Ncov) Outbreak' (2020) 27 Journal of Travel Medicine 2.

197 Bkz 'Uluslararası Sağlık Tüzüğü' (n 72) m 23, 30, 31, 32, 42, 43, 45.

198 Fidler ve Gostin (n 74) 87.

199 Avrupa Konseyi, 'Respecting democracy, rule of law and human rights in the framework of the COVID-19 sanitary crisis: A toolkit for member states' (7 Nisan 2020) (SG/Inf(2020)11).

200 'Avrupa İnsan Hakları Sözleşmesi' (n 187) m 15 (2).

201 Ibid m 15 (1) ve (3).

202 Lawless v. Ireland App no App no 332/57 (ECtHR 1961) para 28.

${ }_{203}$ Mehmet Hasan Altan v. Turkey App no 2016/23672 (ECtHR 2018) para 94, 210.
} 
dahi hukukun üstünlügüne riayet edilmelidir" ilkesi büyük öneme sahiptir. ${ }^{204}$ Öte yandan, AİHM devletlere derogasyona ve sınırlandırmalara başvurulacak durumların belirlenmesinde kayda değer bir takdir marjı vermiş, bu tip durumları ve ortaya çıkan ihtiyaçları en isabetli değerlendirecek mercinin devletler olduğunu belirtmiştir. ${ }^{205}$ Derogasyonun ve sınırlandırmaların sağlık hakkı vb. başkaca hakların korunması amacıyla uygulanması durumunda kanunilik, gereklilik ve ölçülülük ölçütlerine sık1 sıkıya bağlı kalınması gerektiği birçok kararda vurgulanmıştır. ${ }^{206}$ AİHM içtihatlarının kamusal sağlık önlemlerine ilişkin ortaya koyduğu bir başka önemli husus "bireyselleştirilmiş önlem" anlayışıdır. ${ }^{207}$ Buna göre, devletlerin derogasyon ve sinırlandırmalara giderken peşinen topyekûn uygulamaları devreye sokmak yerine her bir birey için özel risk değerlendirmesi yapıp mümkün mertebe daha dar bir kitle için kısıtlayıcı olacak önlemleri tercih etme yükümlülügü mevcuttur. ${ }^{208}$ Elbette COVID-19 salgınının mevcut yaygınlığı karşısında tamamen bireyselleştirilmiş önlem anlayışını uygulamak pek mümkün değildir. Fakat COVID-19'un etkisinin düşeceği ancak tamamen ortadan kalkmayacağı safhalarda bu ilkenin akılda bulundurulması gerekecektir.

COVID-19 salgını ile birlikte özellikle gündeme gelen meselelerden biri, devletlerin kendi vatandaşlarını izlemek üzere uygulamaya soktukları ve genelde kullanımını zorunlu kıldıkları yeni teknolojilerdir. Bu teknolojiler sayesinde devletlere son derece gelişkin takip ve kişisel verilere erişim imkânı doğmaktadır. Dolayısıyla, bu denli geniş çapta bir yetkinin denetime tabi tutulmaması ve suiistimal edilmesi durumunda özel hayatın gizliliği başta olmak üzere birçok temel hakka yönelik ciddi bir tehdit doğacaktır. ${ }^{209}$ Avrupa Konseyi bu tehlikeye önemle dikkat çekmiş ve üye devletleri gerekli denetim mekanizmalarını kurmaları noktasında uyarmıştır. ${ }^{210}$ Avrupa Konseyi’nin 108 Sayılı Kişisel Verilerin Korunması Sözleşmesi’nin güncel versiyonu (Sözleşme 108+ olarak anılmaktadır) söz konusu dengenin ve denetim mekanizmalarının sağlanması için taraf devletler açısından, COVID-19 salgınında geçerli olacak şekilde, temel ölçütleri ortaya koymaktadır. ${ }^{211}$

\footnotetext{
204 Venedik Komisyonu, 'Opinion on the protection of human rights in emergency situation', CDL-AD(2006)015) para 13.

205 Ireland $v$ UK App no 5310/71 (ECtHR 1978) para 207.

206 Yakın tarihteki bir örnek için bkz Lashmankin and Others v Russia App no 57818/09 (ECtHR 2017) para 434.

${ }^{207}$ Enhorn v Sweden App no 56529/00 (ECtHR 2005) para 43-45.

208 Robyn Martin, The Exercise of Public Health Powers in Cases of Infectious Disease: Human Rights Implications" (2006) 14 Medical Law Review 132, 140-143.

209 Yeni teknolojilerin otoriter gözetim veya bireylerin güçlendirilmesi şeklinde iki ayrı şekilde kullanılabileceğini, dolayısıyla toplumların bir tercihle karşı karşıya olduğunu belirtenler mevcuttur, Harari (n 11).

210 Avrupa Konseyi (n 199) 7.

211 'Modernised Convention for the Protection of Individuals with Regard to the Processing of Personal' $<$ https://search.coe. int/cm/Pages/result_details.aspx?ObjectId=09000016807c65b $>$ Erişim Tarihi 13 Haziran 2020.
} 


\section{B. Uluslararası Ticaret Hukuku ve COVID-19}

Günümüze kadar 100'e yakın devlet, DTÖ’ye COVID-19 salgını bağlantılı ticaret kısıtlamalarına gittiğine dair bildirimde bulunmuştur. ${ }^{212} \mathrm{Bu}$ durum, mevcut salgının uluslararası ticaret hukuku üzerindeki doğrudan etkisini açıkça gözler önüne sermektedir. Öte yandan, DSÖ bugüne kadar herhangi bir genel ticaret kısıtlaması önermediği için DSÖ ile DTÖ kararları arasında güncel bir çatışmanın varlığı söz konusu değildir. Kaldı ki DSÖ'nün böyle bir öneri yapması durumda dahi DTÖ'nün buna uyum sağlayacağını öngörmek mümkündür. Zira bilimsel verilere dayanılarak verilen benzer öneriler karşısında DTÖ tarafindan bu yönde bir tutum sergilendiği görülmektedir. ${ }^{213}$ Ancak genel bir öneriden bağımsız olarak birçok devletin çok sayıda kısıtlamaya başvurduğu göz önüne alındığında, uluslararası ticaret hukukunun temeli olan DTÖ düzenlemeleri çerçevesinde mevcut durumun analizini yapmak olası uluslararası uyuşmazlıkları tespit etmek bakımından faydalı olacaktır.

En temel düzenleme konumundaki 1994 tarihli Gümrük Tarifeleri ve Ticaret Genel Anlaşması'nın (GATT) XI. maddesi ihracat veya ithalata konu malların miktarının sinırlanması yahut bu malların ihracat veya ithalatının tamamen yasaklanması durumlarına ilişkin genel kuralı ihtiva etmektedir. XI. maddeye göre, genel olarak bu yöndeki kısıtlamalar yasaktır. Ancak GATT'ın yine aynı maddesinin 2. fikrası ile XII., XX. ve XXI. maddeleri bu yasağa bazı istisnalar getirmektedir. Nitekim COVID-19 salgını ile bağlantılı olarak DTÖ'ye bildirim yapan devletler de genel olarak bu hükümlere dayanmaktadır. GATT m. XI:2(a), bir taraf devletin gıda ve başkaca temel ihtiyaç niteliğindeki mallara dair kritik seviyede bir eksikliğin olması durumunda geçici kısıtlamalara müsaade etmektedir. DTÖ Temyiz Organı'nın ${ }^{214}$ içtihatlarına göre, bu madde kapsamındaki malların "kesin surette vazgeçilemez veya zaruri" olması gereklidir. ${ }^{215}$ Öte yandan, bazı daha özel nitelikteli DTÖ anlaşmalarında GATT $\mathrm{m}$. XI:2'nin uygulanmayacağı düzenlenebilmektedir. Dolayısıyla, bu anlaşmaların kapsamına giren durumlarda söz konusu istisnanın geçerli olmadığı kabul edilecektir. ${ }^{216} \mathrm{Bu}$ sebeple, COVID-19 ile bağlantılı olarak uygulanan kısıtlamalarda $\mathrm{m}$. XI:2’ye dayanılıp dayanılmayacağı mevzubahis mala göre farklılık gösterecektir.

\footnotetext{
212 'COVID-19 and world trade' < https://www.wto.org/english/tratop_e/covid19_e/covid19_e.htm> Erişim Tarihi 13 Haziran 2020.

213 WTO, 'India-Measures Concerning the Importation of Certain Agricultural Products (Report of the Appellate Body)' (4 Haziran 2015) (WT/DS430/AB/R); Kuș giribi olarak bilinin H5N1 virüsü salgınıla ilișkili olan bu kararın daha detaylı incelemesi için bkz Chad Bown, Jennifer Hillman, 'Bird Flu, the OIE, and National Regulation: The WTO's IndiaAgricultural Products Dispute' (2016) 15 World Trade Review 235.

214 DTÖ Temyiz Organı'na ve günümüzde karşı karşıya olduğu krize iliş̧in detaylı bilgiler için bkz Geraldo Vidigal, 'Living Without the Appellate Body: Multilateral, Bilateral and Plurilateral Solutions to the WTO Dispute Settlement Crisis' (2019) 20 Journal of World Investment \& Trade 862.

215 Temyiz Organı Kararı, 'Korea — Various Measures on Beef’ (11 Aralık 2000) (WT/DS161, DS169/AB/R).

216 Bir örnek için bkz Temyiz Organı Kararı, 'Indonesia - Importation of Horticultural Products, Animals and Animal Product' (9 Kasim 2017) (WT/DS477/AB/R, WT/DS478/AB/R)
} 
Öte yandan, GATT m. XX, "insan, hayvan ve bitki yaşamının veya sağlığının korunması için gerekli” önlemlerin normalde yasak olan kısıtlamaları meşrulaştıran bir istisna hâli olduğunu düzenlemektedir. COVID-19 ile bağlantılı kısıtlamaların çoğunu bu madde ile bağdaştırmak mümkündür. Ancak her bir kısıtlamayı gereklilik testine tabi tutarak kesin bir karara varmak daha isabetli olacaktır. ${ }^{217}$ DTÖ Temyiz Organı, tehlike altındaki çıkarların veya değerlerin önemi fazlalaştıkça, m. XX'teki istisnaya dayanabilme olasıllğının da arttığı yönünde bir içtihat ortaya koymuştur. ${ }^{218}$ COVID-19 salgınının doğrudan geniş insan kitlelerinin hayatını tehdit etmesi karşısında, devletlerin m. XX'e başvurabilme ihtimalinin son derece yüksek olduğu şüphesiz bir gerçektir.

GATT m. XII'de, devletlerin ödemeler dengesi ve dış borçlar noktasında sıkıntı çekmesi durumunda devreye giren bir istisna düzenlenmiştir. COVID-19 salgını çerçevesindeki kısıtlamaların şu an için bu hükümle doğrudan ilgili olduğunu söylemek zordur. Ancak salgın sebebiyle ekonomisi ciddi ölçüde bozulan birçok devletin gelecekte uygulayabileceği ek kısıtlamalarda bu maddenin önem kazanacağı öngörülebilir. GATT m. XXI.'de düzenlenen istisna hâli ise taraf devletlerin ulusal güvenliklerini korumalarıyla ilgilidir. Genişletici bir yorumla, mevcut salgının ulusal güvenliği tehdit eden bir unsur olarak görülmesi ve uygulamaya sokulan kısıtlamaları meşrulaştırmak amacıyla m. XXI'e dayanılması düşünülebilir. Ancak m. XXI:2'de yer alan detaylara bakıldığında, işbu maddede esas olarak askeri güvenliğin kastedildiği yönünde bir izlenim doğmakta ve söz konusu izlenim salt salgının ulusal güvenlik istisnaları arasında görülemeyeceği şeklinde daraltıcı bir yorumu daha makul hâle getirmektedir. Öte yandan, GATT dışında kalan bazı özel nitelikli DTÖ anlaşmaları da COVID-19 salgını ile bağlantılı kısıtlamaları doğrudan ilgilendiren hükümlere sahiptir. Örneğin, Sağlık ve Bitki Sağlı̆̆ Anlaşması, GATT m. XX ile neredeyse aynı içeriğe sahip bir hükmü ihtiva etmektedir. ${ }^{219}$

Salgın ve uluslararası ticaret hukuku arasındaki hukuki bağlantı, devletlerin uygulamaya koyduğu ticaret kısitlamalarıyla sınırlı değildir. Salgına sebep olan hastalığa dair ilaç ve aşı çalışmaları ile uluslararası ticaret hukukunun bir cüzü olan fikri mülkiyet hukuku arasında çok önemli bir ilişki mevcuttur. Zira uluslararası fikri mülkiyet hukuku düzenlemeleri uyarınca, her ürün gibi ilaç ve aşılar da patent korumasına tabidir. ${ }^{20}$ Dolayısıyla, COVID-19 benzeri bulaşıcı hastalıklara dair ilaç veya aşının bulunması durumunda bunların ilk bulan tarafindan patent korumasına tabi kılınması ve bulanın bu ürünlerin ticaretinde küresel tekel hâline gelmesi

\footnotetext{
217 Siddharth S Aatreya, 'Are COVID-19 Related Trade Restrictions WTO-Consistent?' (EjilTalk, 25 Nisan 2020) <www. ejiltalk.org/are-covid-19-related-trade-restrictions-wto-consistent> Erişim Tarihi 14 Haziran 2020.

218 Temyiz Organı Kararı, 'European Communities - Measures Affecting Asbestos and Asbestos-Containing Products' (12 Mart 2001) (WT/DS135/AB/R).

219 DTÖ Sağlık ve Bitki Sağlığı Anlaşması (1995) (SPS) m 2.

220 DTÖ Ticaretle Bağlantılı Fikri Mülkiyet Anlaşması (1995) (TRIPS) m 27.
} 
gündeme gelmektedir. ${ }^{221}$ Böyle bir durum kaçınılmaz olarak, küresel sağlık hedefleri ve uluslararası salgınlarla etkili mücadele ile fikri mülkiyet hukuku arasında bir gerilim doğurmuştur. Nitekim bu gerilim, uluslararası hukuk doktrininde kapsamlı değerlendirmelere konu olmuştur. ${ }^{22}$ Söz konusu gerilimi çözmek amacıyla atılmış en önemli adımlardan biri 2001 tarihli, Ticaretle Bağlantılı Fikri Mülkiyet Anlaşması (TRIPS) ve Kamu Sağlığına ilişkin Doha Deklarasyonu'dur. ${ }^{223}$ Doha Deklarasyonu, "ulusal acil durum veya diğer olağanüstü zaruret durumlarında" taraf devletlerin, normalde patent korumasına sahip tıbbi ürünlerin üretilmesi için patent sahibi olan üreticiler dışındaki üreticileri yetkilendirebilmesinin önü açılmıştır. ${ }^{224}$ Doha Deklarasyonu'nun ortaya koyduğu bu istisna hiç şüphesiz ki COVID-19 salgınında birçok devlet için geçerli olacaktır.

\section{Uluslararası Kolektif Güvenlik Sistemi ve COVID-19}

2005 tarihli UST çerçevesinde "sağlık önlemlerinin" kapsamına herhangi bir hukuki yaptırım veya güvenlik tedbiri girmese de ${ }^{225}$ salgınlara karşı uluslararası ölçekte mücadelenin doğrudan bir güvenlik boyutu olduğu da kabul edilmelidir. ${ }^{226}$ Hatta güvenlik boyutunun göz ardı edilmesi çoğu zaman salgına karş1 mücadelenin etkisini zayıflatabilecektir. Bu bakımdan, akla ilk gelmesi gereken konu, uluslararası barış ve güvenliğin korunmasından sorumlu küresel kolektif güvenlik mekanizması konumundaki ${ }^{227} \mathrm{BM}$ Güvenlik Konseyi'nin salgınlarla mücadeledeki rolüdür.

BM Güvenlik Konseyi, bir meselenin uluslararası barış ve güvenliği tehdit edip etmediğine karar vermek noktasında büyük ölçüde serbesttir. ${ }^{228}$ Nitekim 21. yüzyılda uluslararası barış ve güvenliğe tehdit arz eden durumların sadece devletler arasındaki silahlı çatışmalar ile sınırlı olması düşünülmemelidir. Yaygın iç savaşlar, sınır aşan silahlı terör örgütleri ve başkaca örgütlü suç şebekeleri, çevresel tehditler ve kıtllk gibi birçok mesele küresel düzeni tehdit edecek etkiler yaratabilmektedir. Salgınlar da hiç şüphe yok ki uluslararası ölçekte yıkıcı sonuçlar doğurabilmeleri itibariyle bu durumlar arasında sayılmalıdır. BM eski Genel Sekreteri Kofi Annan'in 2005'te kamu sağlığının önemini vurgulaması ve Güvenlik Konseyi’nin “uluslararası barış

${ }^{221}$ Frederick Abbott, 'Health and Intellectual Property Rights' in Gian Luca Burci and Brigit Toebes (eds), Research Handbook on Global Health Law (Edward Elgar 2018) 139.

222 Bu konuda öne çıkan bazı örnekler için bkz Ibid ; Ellen Hoen, 'TRIPS, Pharmaceutical Patents, and Access to Essential Medicines: A Long Way from Seattle to Doha' (2002) 3(1) Chicago Journal of International Law 27.

223 Doha Deklarasyonu (WT/MIN(01)/DEC/2) (2001); detaylı inceleme için bkz Gostin, Global Health Law (n 21) 298-301.

224 'Doha Deklarasyonu' (n 223) para 5(b), (c).

225 'Uluslararası Sağl1k Tüzüğü' (n 72) m 1(1).

226 Bogdandy ve Villarreal, 'International Law on Pandemic Response: A First Stocktaking In Light of the Coronavirus Crisis' (n 36) 22.

227 Birleşmiş Milletler Şartı (1945) m 24.

228 Ntina Tzouvala, 'COVID-19, international law and the battle for framing the crisis' (International Law Association Reporter, 25 Mart 2020)<https://bit.ly/33K5tBy> Erişim Tarihi 14 Haziran 2020. 
ve güvenliği tehdit eden bulaşıcı hastalıklara karşı eyleme geçmesi” gerekliliğini vurgulamış olması bu gerçeği göstermektedir. ${ }^{229}$

BM Güvenlik Konseyi uygulamasına bakıldığında salgınlara karşı tutumun her vakada aynı şekilde olmadığı görülmektedir. Bugüne kadarki birçok salgını uluslararası barış ve güvenliğe tehdit olarak nitelemeyen Güvenlik Konseyi'nin, 2014 ile 2016 y1lları arasında Batı Afrika'da görülen Ebola ${ }^{230}$ salgınında bu vakayı uluslararası barış ve güvenliğe tehdit ilân ettiği görülmektedir. İşbu Karar, Güvenlik Konseyi'nin bir salgını uluslararası barış ve güvenliğe tehdit olarak nitelediği ilk örnektir. Hatta Güvenlik Konseyi’nin mevzubahis Ebola salgınına ilişkin oybirliğiyle aldığı 2014 tarihli ve 2177 sayılı Karar (buna ek olarak BM Genel Kurulu'nun aynı yıl aldığı 69/1 sayılı Karar), BM Şartı 7. Bölüm'deki yaptırım yetkilerine başvurmasa da BM bünyesinde sirf bu salgına özel bir misyon olan BM Ebola Acil Müdahale Misyonu'nun (UNMEER) kurulmasına yolu açması bakımından son derece dikkat çekicidir. 2177 sayılı Karar'da devletlere teknik uzmanlık ve malzeme tedariki bakımından yardımda bulunmaları çağrısı yapılmış, ayrıca DSÖ'den salgın ilânı yaparak Ebola'ya yönelik alınacak tedbirlerin hızlandırılmasını sağlaması talep edilmiştir.

Daha yakın bir dönemde, Demokratik Kongo Cumhuriyeti'nde baş gösteren 20182020 Ebola salgını da iki Güvenlik Konseyi Kararı'na konu olmuştur. ${ }^{231}$ Ancak işbu Kararlar söz konusu salgını uluslararası barış ve güvenliğe tehdit olarak nitelememiş, daha ziyade salgın sırasında bölgedeki silahlı çatışmalarda insancıl hukuk yükümlülüklerine riayet edilmesine ve diğer devletlerin salgınla mücadeleye destek vermesine ilişsin hususlara yer verilmiştir. 2011'de alınan AIDS salgınına iliş̧in Güvenlik Konseyi Kararı da benzer bir şekilde salgınla bağlantılı başka hususlara değinmek üzere alınmış, bu Karar'da bilhassa BM Barış Gücü Birlikleri'nin rolüne odaklanılmıştır. ${ }^{232}$

Her vakada BM Güvenlik Konseyi'nin salgını uluslararası barış ve güvenliğe tehdit olarak nitelemesi ve böylece, BM Şartı 7. Bölümü’ndeki yaptırımlara yolun açılmasının pek iyi bir tercih olmayacağına, zira böyle bir tercihin uluslararası toplumda korkuyu yayabileceğine ve vahim sosyoekonomik sonuçlar doğurabileceğine dikkat çekilmektedir. ${ }^{233}$ Ayrıca Güvenlik Konseyi’nin güvenliğe ilişkin geniş yetkilerini her vakada kullanması gibi bir uygulamanın gelişmesi durumunda salgınlarla mücadelede kamu sağlı̆̆ına ilişkin önceliklerden ziyade güvenlikçi bir zihniyetin öne çıkması gibi

\footnotetext{
229 'In larger freedom: towards development, security and human rights for all' $<$ https://undocs.org/A/59/2005 $>$ Erişim Tarihi 14 Haziran 2020

230 BM Güvenlik Konseyi Kararı 2177 (2014).

231 BM Güvenlik Konseyi Kararı 2463 (2019).

232 BM Güvenlik Konseyi Kararı 1983 (2011).

233 Caroline Sell, 'Ebola and Emerging Infectious Diseases in Armed Conflict: Contemporary Challenges in Global Health Security Laws and Policies' (2020) 29 Minn J Int'l L 187, 214.
} 
bir risk de mevcuttur. ${ }^{234}$ Öte yandan, Güvenlik Konseyi'nin bu belirsiz tutumu sürdükçe hangi kamusal sağlık tehditlerinin uluslararası barış ve güvenliğe tehdit niteliğinde görüleceğine dair ölçütler belirsiz kalmaktadır. Ayrıca her bir vakada bilimsel verilerden ziyade politik hesapların ağır basması gibi bir risk ortaya çıkmaktadır. En nihayetinde, olumlu ve olumsuz yönleriyle, Güvenlik Konseyi'nin mevcut tutumunun her bir vakanın kendi koşullarına göre değişken mahiyette olduğu açıktır. ${ }^{235}$

COVID-19 salgınının uluslararası barış ve güvenliğe tehdit olarak görülüp görülemeyeceğini değerlendirmek için en isabetli yöntem Güvenlik Konseyi’nin 2177 sayılı Kararı aldığ şartlarla bir mukayese yapmaktır. O dönemde Ebola iki yıllık bir süreçte 30.000'e yakın insana bulaşırken COVID-19 salgınında bu sayıya sadece iki ayda kısa bir sürede ulaşılmıştır. Bu sayı hâlâ katlanarak artmaktadır. COVID-19'un ölümcüllük seviyesi Ebola kadar olmasa da vaka sayısının yüksekliğinden ötürü toplam ölüm sayısı yine çok yüksek bir seviyededir. Ayrıca, Ebola çok büyük ölçüde bölgesel ölçekte (Batı Afrika) bir salgın olarak kalırken, COVID-19 dünyanın neredeyse her yerine yayılmış durumdadır. Bu mukayese sonucunda, COVID-19'un Güvenlik Konseyi tarafından uluslararası barış ve güvenliğe tehdit olarak nitelenmemesi için bir sebep gözükmemektedir. Hatta salgınla etkili mücadele için Güvenlik Konseyi'nin ivedi bir şekilde devreye girerek karar alması gerektiğini savunanlar mevcuttur. ${ }^{236}$ Ancak Güvenlik Konseyi'nin bugüne kadar BM Genel Sekreteri'nin COVID-19 salgını süresince dünyadaki tüm silahlı çatışmalara ara verilmesi çağrısın1 $1^{237}$ destekleyici bir karar almakta dahi oldukça gecikmiştir. ${ }^{238}$ En nihayetinde, 1 Temmuz 2020 tarihinde bir karar alınabilmiş ve bu kararda COVID-19 salgınının uluslararası barış ve güvenliğin korunmasını tehdit potansiyeli taşıdığı belirtilmiştir. Ayrıca, BM Genel Sekreteri'nin yukarıda belirtilen ateşkes çağrısı benimsenmiş ve ismi zikredilen bazı terör örgütlerine yönelik opersyonlar haricinde tüm silahlı çatışmalara 90 gün süreyle insani yardıma erişim amacıyla ara verilmesine karar verilmiştir. Karar'da vurgulanan diğer noktalar ise kadınların COVID-19 krizi ile mücadeledeki kritik rolü ve mevcut krizin mülteciler ile çocuklar gibi kırılgan durumdaki kesimlerin üzerindeki orantısız etkisinin asgariye indirilmesi gerekliliğidir. ${ }^{239}$

\footnotetext{
${ }^{234}$ Jiyong, Joe Karackattu, 'Infectious Diseases and Securitization: WHO's Dilemma' (2011) 9 Biosecurity and Bioterrorism 181, 184.

235 Bogdandy ve Villarreal, 'International Law on Pandemic Response: A First Stocktaking In Light of the Coronavirus Crisis' (n 36) 23; Ilja Pavone, 'Ebola and Securitization of Health: UN Security Council Resolution 2177/2014 and Its Limits' in Leonie Vierck, Pedro A Villarreal ve Katarina Weilert (eds), The Governance of Disease Outbreaks International Health Law: Lessons from the Ebola Crisis and Beyond (Nomos 2017), 308-311.

236 Marko Svicevic, 'COVID-19 as a Threat to International Peace and Security: What place for the UN Security Council?' (EjilTalk, 27 Mart 2020) <ejiltalk.org/covid-19-as-a-threat-to-international-peace-and-security-what-place-for-the-unsecurity- council/> Erişim Tarihi 16 Haziran 2020.

237 "COVID-19: UN chief calls for global ceasefire to focus on "the true fight of our lives" < https://news.un.org/en story/2020/03/1059972> Erişim Tarihi 17 Haziran 2020.

238 'UN Security Council Fails to Support Global Ceasefire, Shows No Response to COVID-19' (Reliefweb, 19 May1s 2020) $<$ https://reliefweb.int/report/world/un-security-council-fails-support-global-ceasefire-shows-no-response-covid-19> Erişim Tarihi 17 Haziran 2020

239 BM Güvenlik Konseyi Kararı 2532 (2020).
} 
Elbette, Çin'in Güvenlik Konseyi'ndeki daimi üye statüsünün ona verdiği veto yetkisi sebebiyle, Konsey'den çıkacak olası birkararın içeriği konusunda bir uzlaşmaya varılması kolay olmayacaktır. Ancak önemle ifade etmek gerekir ki başvurulabilecek yollardan biri, Çin'in veto yetkisinin olmadığ $\mathrm{BM}$ Genel Kurulu'ndan -daha önce AIDS salgınında olduğu gibi- birtakım kararlar çıkarılmasıdır. Bilhassa Genel Kurul'un Uluslararası Adalet Divanı'ndan danışma görüşü talep etme yetkisi, salgın sürecine dair hukuki yükümlülüklerin tespiti bakımdan önümüzdeki süreçte kayda değer bir tercih olabilir. ${ }^{240}$

\section{Sonuç}

COVID-19 salgını sadece bir uluslararası sağlık krizi olmakla kalmayıp ekonomik, politik, toplumsal ve kültürel etkileri olan küresel bir krizdir. Yoğun derecede küreselleşmiş ve sınır kontrollerinin neredeyse imkansız hâle geldiği bir dünyada ortaya çıkmış, hızla dünyanın dört bir köşesine yayılmış ve tüm uluslararası sistemi felç etmiştir. Böylesine bir salgınla mücadelenin küresel ölçekte bir işbirliği ve mevcut sorundan etkilenen tüm paydaşların koordinasyonu olmadan gerçekleştirilmesi imkânsız gözükmektedir.

Böyle bir ihtiyaç karşısında, küresel sağlık yönetiminin ve uluslararası sağlık hukukunun odağ konumundaki DSÖ’nün yönetim kapasitesinin ne yönde gelişeceği büyük bir merak konusudur. DSÖ’nün COVID-19 salgını sırasındaki performansı, örgütün bağımsızlı̆ıı tartışmalarından finansmanına, örgüt organlarının yetkilerinden düzenlemelerinin yeterliliğine kadar birçok konunun tartışılmasına sebep olmaktadır. Bir tarafta DSÖ sisteminin geliştirilmesi ve güçlendirilmesi ihtiyacına vurgu yapılırken, öte tarafta başta DSÖ ve AB gibi uluslararası örgütlerin mevcut salgındaki verimsiz ve yetersiz performansı sebebiyle ulusal sağlık altyapı ve sistemlerinin güçlendirilmesi ve kendi kendine yeterli hâle gelmesi ihtiyacı da gündeme gelmektedir. Gerçekten de DSÖ'nün salgın sürecindeki performansının o veya bu sebepten ötürü yetersiz kaldığ 1 kanaatini güçlendirecek bazı noktalar mevcuttur. Ancak bu durum, DSÖ'nün uluslararası toplum için ortaya çıkması onlarca yıl almış çok önemli bir kazanım olduğu gerçeğini değiştirmemektedir. Öncelikle, DSÖ’nün bazı eksikliklerinin ve hatalarının faturasını örgütten ziyade devletlere kesmek daha doğru olacaktır. İkincisi, tüm eksikliklerine ve gecikmelerine rağmen DSÖ’nün salgınlarla mücadelede küresel ölçekte teknik uzmanlığın harekete geçirilmesi ve koordine edilmesi noktasında başarılı işler yaptığı da görülmektedir. Bilhassa DSÖ’nün 2005 tarihli Uluslararası Sağlık Tüzüğü, günümüzde çok katmanlı bir küresel sağlık yönetimi mekanizması sunmaktadır. Bu bakımdan, uluslararası toplum için büyük bir kazanımdır. Ancak devletlerin üstlerine düşen yükümlülükleri yerine getirmemesi durumunda dahi etkili olacak sihirli bir değnek değildir. COVID-19 vaka sayılarını

240 Uluslararası Adalet Divanı Şartı (1945) m 96. 
azaltarak günlük hayatın ve uluslararası sistemin normale dönüşünü sağlamak için devletler başta olmak üzere tüm paydaşlara önemli sorumluluklar düşmektedir. Sırf bazı bildirim yükümlülüklerinin kendi ekonomilerine ve siyasi çıkarlarına zarar vereceği endişesiyle devletlerin DSÖ düzenlemelerine riayet etmemeleri, kimi devletlerin bu düzenlemeleri hayata geçirecek sağlık altyapısına sahip olmaması veya DSÖ'nün diğer ilgili küresel yönetim mekanizmalarıyla yeterli koordinasyonu kuramaması durumunda, sağlık sisteminin küresel ölçekte gelişememesi, salgınlar sırasında uluslararası ticaret ve seyahate yönelik önlemlerin eşgüdümlü olmaması ve küresel çapta bilimsel işbirliğinin gerçekleştirilememesi gibi olumsuz sonuçlar ortaya çıkmaktadır. Bu sebeple, DSÖ’ye yönelik sorgulamalar ve tartışmalar eğer mevcut küresel sağlık yönetim sistemini ve 2005 tarihli UST’nin öngördüğü hukuki rejimi zayıflatmak yerine daha etkili kılacak; sistemin daha sürdürülebilir, şeffaf ve kapsayıcı olmasını sağlayacak şekilde sonuçlanırsa uluslararası toplumun geneli için faydalı olacaktır. Yani DSÖ’nün ve küresel yönetim mekanizmalarının zayıflatılması değil, daha da güçlendirilecek şekilde revize edilmesi ihtiyacı vardır. Zira uluslararası toplumun 21. yüzyılın bu ilk küresel sağlık krizine yeterince başarılı bir karşılık verememiş olması, küresel yönetim ve uluslararası hukuk mekanizmalarının anlamsızlığını değil, bu mekanizmaların yeterince ve başarılı bir şekilde işletilememiş olduğunu göstermektedir.

Uluslararası insan hakları hukuku, uluslararası ticaret hukuku ve uluslararası kolektif güvenlik sistemi başta olmak üzere uluslararası hukukun birçok alanının salgınlarla mücadelede oynadığ 1 önemli roller göz ardı edilmemelidir. Ayrıca, salgınların bu alanlardaki normları etkilemesi de söz konusudur. Bu sebeple, uluslararası toplumun salgınlarla mücadelede işbirliğini gözetmesi ve güçlendirmesi gereken tek alan uluslararası sağlık hukuku olmayıp küresel sağlı yönetimiyle tüm bu alanlardaki küresel yönetim mekanizmalarının uyum içerisinde hareket etmesi için gerekli adımların atılması uluslararası toplumun öncelikli gündemlerinden biri olmalıdır.

COVID-19 salgını uluslararası işbirliği ve küresel yönetim mekanizmalarının 21. yüzyılda hâlâ ne denli kırılgan, parçalı ve hukukun üstünlüğüne uyulması noktasında zorlayıcılıktan uzak olduğunu göstermesi sebebiyle mevcut uluslararası hukuk sisteminin birçok açıdan sorgulanmasına yol açsa da gerek küresel sağlık yönetimi gerek diğer alanlardaki uluslararası işbirliği mekanizmalarının güçlendirilmesi için uluslararası sistemin temel aktörleri konumundaki devletlerin bu yönde genel bir irade ortaya koyması elzemdir. Nitekim günümüz uluslararası hukukunun devletlerin kamu sağlığı konusunda kendi ülke sınırlarını aşacak düzeyde bir sorumluluk göstermesini, şeffaf olmasını, ilgili verileri paylaşmasını ve diğer devletlerin yanı sıra ilgili uluslararası örgütlerle işbirliği içerisinde olmasını öngörmesi, bir başka deyişle kötü yönetime cevaz vermemesi, böyle bir iradenin ortaya çıkmasını zaruri k1lmaktadır. 
Sonuç olarak, tüm uluslararası toplumu derinden etkileyen bu küresel krizden bir an önce çıkılması için devletlerin ve diğer uluslararası aktörlerin sağlıklı bilgi ve veri havuzu oluşturdukları, lojistik ve üretim kapasitelerini koordine ettikleri, kırılgan ülke ve bölgeler için gerekli finansman kaynaklarını yarattıkları, temel tıbbi ihtiyaçların rahat dolaşımına izin verdikleri, ticari yahut seyahata ilişkin kısıtlamaları birbirine uyumlu hâle getirmeye çalıştıkları, temel insan haklarına saygıyı esas aldıkları, ve küresel sağlık meselesinin güvenlik boyutunu göz ardı etmedikleri bir uluslararası işbirliği zemini geliştirilebilmelidir. Çağımızda salgınlarla etkili ve verimli mücadele, salt ulusal ölçekteki adımlarla değil fakat devletlerin uluslararası işbirliğine yönelik sağlam bir taahhüt vermeleri ve bu taahhütler sonucunda oluşan uluslararası hukuk kurallarının üstünlügüne riayet etmeleriyle mümkündür. Tüm sınırların kapatıldığı, her devletin bu zorlu krizde kendi başının çaresine bakmaya çalıştı̆̆ı, devletlerin kendi vatandaşları üzerindeki sıkı kontrolünü ciddi boyutlarda pekiştirdiği içe kapanmacı bir yol yerine, krizin dünyanın her köşesini etkilediği ve herkesin aynı gemide olduğu gerçeğinin kavranmasıyla daha fazla uluslararası işbirliğini gözeten, devletlerin yanı sıra küresel yönetim mekanizmalarının ve devletdışı aktörlerin karar alma süreçlerine katılımının arttırıldığı, karar alma süreçlerinde daha çok şeffaflığın sağlandığı bir yol tercih edilmelidir.

Küresel kamu sağlığı, dünyamızın yakın geleceğinde insanlığ 1 ilgilendiren en önemli meselelerden biri olmay1 sürdürecektir ve hiçbir uluslararası aktörün bu konuda sorumluluk almaktan kaçınma lüksü yoktur. Küresel işbirliğinin COVID-19 gibi salgınlarla etkili mücadelede daha çok uluslararası hukuk mu yoksa daha az uluslararası hukuk mu gerektiği noktasında tercih edilmesi gereken seçenek ilkidir. Yani, uluslararası hukukta etkin düzenlemelerin sayısı arttırılmalıdır. Uluslararası hukuk bizlerin en önemli küresel değer sistemi olmalıdır.

Hakem Değerlendirmesi: Dış bağımsız.

Çıkar Çatışması: Yazarlar çıkar çatışması bildirmemiştir.

Finansal Destek: Yazarlar bu çalışma için finansal destek almadığını beyan etmiştir.

Peer-review: Externally peer-reviewed.

Conflict of Interest: The authors has no conflict of interest to declare.

Grant Support: The authors declared that this study has received no financial support. 


\section{Bibliyografya/Bibliography}

'2019 Novel Coronavirus (2019-nCoV): Strategic Preparedness And Response Plan' (WHO, 4 Şubat 2020) <https:/www.who.int/docs/default-source/coronaviruse/srp-04022020.pdf.> Erişim Tarihi 25 Mayıs 2020.

'About COVID-19' <http://www.emro.who.int/health-topics/corona-virus/about-covid-19.html> Erişim Tarihi 18 Mayıs 2020.

'BM Ekonomik ve Sosyal Konsey Açıklaması' (17 Nisan 2020) (E/C.12/2020/1).

'C.D.C. and W.H.O. Offers to Help China Have Been Ignored for Weeks' (New York Times, 7 Şubat 2020) <https://www.nytimes.com/2020/02/07/health/cdc-coronavirus-china.html> Erişim Tarihi 17 Mayss 2020.

'Challenges of Global Governance Amid the COVID-19 Pandemic' (CFR, May1s 2020) <https:// cdn.cfr.org/sites/default/files/report_pdf/challenges-of-global-governance-amid-the-covid-19pandemic.pdf> Erişim Tarihi 28 Mayıs 2020.

'Coronavirus (COVID-19)' (CDC) <https://www.cdc.gov/coronavirus/index.html> Erişim Tarihi 15 Mayis 2020.

'COVID-19 and HIV' < https://www.unaids.org/en> Erişim Tarihi 29 Mayıs 2020.

'COVID-19 and International Law: What went wrong and what can we learn from it?' (BIICL, 16 Nisan 2020) $<$ https://www.biicl.org/documents/10303_covid19_and_international_law_16_ april_2020_event_report.pdf $>$ Erişim Tarihi 23 Mayıs 2020.

'COVID-19 and world trade' <https://www.wto.org/english/tratop_e/covid19_e/covid19_e.htm> Erişim Tarihi 13 Haziran 2020.

'COVID-19 Solidarity Response Fund' $(W H O)<$ https://www.who.int/emergencies/diseases/novelcoronavirus-2019/donate> Erişim Tarihi 25 Mayıs 2020.

'COVID-19 Strategic Preparedness and Response Plan: Operational Planning Guidelines to Support Country Preparedness and Response' (WHO, 12 Şubat 2020) <https://www.who.int/ docs/default-source/coronaviruse/covid-19-sprp-unct-guidelines.pdf?sfvrsn=81ff43d8_4> Erişim Tarihi 25 Mayıs 2020

'COVID-19 Triggers Marked Decline in Global Trade' (UNCTAD, 13 Mayıs 2020) < https://unctad. org/en/Pages/PressRelease.aspx?OriginalVersionID=553> Erişim Tarihi 15 May1s 2020.

'COVID-19: UN chief calls for global ceasefire to focus on "the true fight of our lives" $<$ https:// news.un.org/en/story/2020/03/1059972> Erişim Tarihi 17 Haziran 2020.

'Declaration of Alma-Ata' (WHO, Eylül 1978) < https://www.who.int/publications/almaata declaration en.pdf.ua=1.> Erişim Tarihi 15 Mayıs 2020.

'Dünya Sağlık Örgütü Anayasası' (WHO, Ekim 2006) <https://www.who.int/governance/eb/who_ constitution_en.pdf $>$ Erişim Tarihi 20 Mayıs 2020.

'European Union: are borders the antidote to the Covid-19 pandemic?' (The Conversation, 17 Nisan 2020) $<\mathrm{https}$ ://theconversation.com/european-union-are-borders-the-antidote-to-the-covid-19pandemic-136643> Erişim Tarihi 16 Haziran 2020.

'Fighting the Coronavirus Pandemic: China's Influence at the World Health Organization' (IM, 23 Mart 2020) <https://www.institutmontaigne.org/en/blog/fighting-coronavirus-pandemicchinas-influence-world-health-organization> Erişim Tarihi 27 Mayıs 2020.

'First World Health Assembly' $(W H O)<$ https://www.who.int/global_health_histories/first_world health_assembly/en/> Erişim Tarihi 20 Mayıs 2020. 
'Has covid-19 killed globalisation?' (The Economist, 14 Mayıs 2020) <https://www.economist. com/leaders/2020/05/14/has-covid-19-killed-globalisation?utm source=dailybrief\&utm medium=email\&utm_campaign=DailyBrief2020May15\&utm_term=DailyNewsBrief; $>$ Erişim Tarihi 15 Mayis 2020.

'How the IMF Can Help Countries Address the Economic Impact of Coronavirus' < https://www. imf.org/en/About/Factsheets/Sheets/2020/02/28/how-the-imf-can-help-countries-address-theeconomic-impact-of-coronavirus> Erişim Tarihi 15 Mayıs 2020.

'In larger freedom: towards development, security and human rights for all' <https://undocs. org/A/59/2005> Erişim Tarihi 14 Haziran 2020.

'International Sanitary Regulations' <https://apps.who.int/iris/bitstream/handle/10665/85636/ Official_record37_eng.pdf?sequence=1\&isAllowed=y $>$ Erişim Tarihi 10 Haziran 2020.

'Modernised Convention for the Protection of Individuals with Regard to the Processing of Personal' $\quad<$ https://search.coe.int/cm/Pages/result_details.aspx?ObjectId $=09000016807 \mathrm{c} 65 \mathrm{~b}>$ Erişim Tarihi 13 Haziran 2020.

'Much of global commerce has ground to a halt' (The Economist, 21 Mart 2020) <https://www. economist.com/business/2020/03/21/much-of-global-commerce-has-ground-to-a-halt> Erişim Tarihi 15 Mayis 2020.

'Notification of 18 March 2020'<https://rm.coe.int/09000016809cf9a2.> Erişim Tarihi 2 Haziran 2020.

'Origin and development of health cooperation' (WHO) < https://www.who.int/global_health histories/background/en/> Erişim Tarihi 20 Mayıs 2020.

'Regulations Regarding Nomenclature' $(W H O)<$ https://www.who.int/classifications/icd/docs/en/ NOMREGS.pdf $>$ Erişim Tarihi 29 Mayıs 2020.

'Statement of the Global Health Law Committee of the International Law Association regarding the COVID-19 Pandemic' ( ILA, 5 Nisan 2020) <https://www.ila-americanbranch.org/news/article/ statement-of-the-global-health-law-committee-of-the-international-law-association-regardingthe-covid-19-pandemic/> Erişim Tarihi 18 Mayıs 2020.

'Statement on the Second Meeting of the International Health Regulations (2005) Emergency Committee Regarding the Outbreak of Novel Coronavirus (2019-nCoV)' (WHO, 30 Ocak 2020) $<$ https://www.who.int/news-rooni/detail/30-01-2020-statement-on-the-second-meeting-of-theintern ational-health-regulations-(2005)-emergency-committee-regarding-the-outbreak-of-novelcoronavi rus-(2019-ncov)> Erişim Tarihi 24 Mayıs 2020.

'Ten Threats to Global Health in 2019' (WHO) < https://www.who.int/news-room/feature-stories/ ten- threats-to-global-health-in-2019> Erişim Tarihi 18 Mayis 2020.

'The Collapse of Global Cooperation under the WHO International Health Regulations at the Outset of COVID-19: Sculpting the Future of Global Health Governance' (ASIL, 5 Haziran 2020)

'Uluslararas1 Sağlık Tüzüğü' (WHO, 2005)<https:/www.who.int/ihr/publications/9789241580496/ en/> Erişim Tarihi 21 Mayıs 2020.

'UN Security Council Fails to Support Global Ceasefire, Shows No Response to COVID-19' (Reliefweb, 19 Mays 2020) <https://reliefweb.int/report/world/un-security-council-failssupport-global-ceasefire-shows-no-response-covid-19> Erişim Tarihi 17 Haziran 2020.

'UPDATE 2-Burundi kicks out WHO team amid election campaign' (Reuters, 14 May1s 2020) $<$ https://www.reuters.com/article/health-coronavirus-burundi/update-1-burundi-expels-nationalwho-head-during-election-campaign-idUSL8N2CW2LB> Erişim Tarihi 26 Mayıs 2020. 
'WHO Coronavirus Disease (COVID-19) Dashboard' (WHO) <https://covid19.who.int. $>$ Erişim Tarihi 18 May1s 2020.

'WHO Director-General's opening remarks at the media briefing on COVID-19' (WHO, 11 Mart 2020) <https://www.who.int/dg/speeches/detail/who-director-general-s-opening-remarks-atthe-media-briefing-on-covid-19---11-march-2020> Erişim Tarihi 25 Mayıs 2020.

'Who Framework Convention On Tobacco Control' (WHO, 2003) < https://apps.who.int/iris/ bitstream/handle/10665/42811/9241591013.pdf?sequence=1> Erişim Tarihi 29 Mayss 2020.

'WHO Timeline - COVID-19' (WHO) <https://www.who.int/news-room/detail/27-04-2020-whotimeline---covid-19> Erişim Tarihi 24 Mayıs 2020.

'World Bank Group President David Malpass Remarks to G20 Leaders'Virtual Summit' (WorldBank, 26 Mart 2020) <http://documents.worldbank.org/curated/en/964171585579938056/pdf/ Remarks-by-World-Bank-Group-President-David-Malpass-to-G20-Leaders-Virtual-Summit. pdf $>$ Erişim Tarihi 15 Mayıs 2020

'World Experts and Funders Set Priorities for COVID-19 Research' (WHO, 12 Şubat 2020) <https:// www.who.int/news-room/detail/12-02-2020-world-experts-and-funders-set-priorities-for-co vid-19-research.> Erişim Tarihi 25 Mayıs 2020.

'Wuhan Yerel Halk Komisyonu' (WJW, 31 Aral1k 2019) <http://wjw.wuhan.gov.cn/front/web/ showDetail/2019123108989> Erişim Tarihi 16 Mayıs 2020.

$<$ asil.org/insights/volume/24/issue/15/collapse-global-cooperation-under-who-internationalhealth-regulations > Erişim Tarihi 28 Mayıs 2020.

1892 tarihli Uluslararası Sağlık Sözleşmesi için bkz <https://www.loc.gov/law/help/us-treaties/ bevans/m-ust000001-0359.pdf> Erişim Tarihi 19 Mayıs 2020.

Abbott F, 'Health and Intellectual Property Rights' in Gian Luca Burci and Brigit Toebes (eds), Research Handbook on Global Health Law (Edward Elgar 2018) 139.

Abeysinghe S, Pandemics, Science and Policy. H1N1 and the World Health Organization (Palgrave Macmillan 2015).

Abhijit Iyer-Mitra, 'WHO and China covered Tedros' past — but what is worrying is how India fell for it' (ThePrint, 13 Nisan 2020) <https://theprint.in/opinion/who-and-china-tedros-pastworrying-how-india-fell-for-it/400945/> Erişim Tarihi 28 Mayıs 2020.

Aginam O, 'Globalization of Health Insecurity: The World Health Organization and the New International Health Regulations’ (2006) 25 Medicine \& Law 663.

Anderson M vd, 'Coronavirus Compensation? Assessing China's Potential Culpability and Avenues of Legal Response' (Henri Jackson Society, 5 Nisan 2020) < https://henryjacksonsociety.org/ publications/coronaviruscompensation/> Erişim Tarihi 16 Haziran 2020 .

Anne-Marie Slaughter, 'Redefining National Security for the Post-Pandemic World' (Project Syndicate, 3 Haziran 2020), <https://www.project-syndicate.org/commentary/redefiningnational-security-for-world-after-covid19-by-anne-marie-slaughter-2020-06> Erişim Tarihi 16 Haziran 2020. attainable standard of health (2000) (E/C.12/2000/4).

Avrupa Konseyi, 'Respecting democracy, rule of law and human rights in the framework of the COVID-19 sanitary crisis: A toolkit for member states' (7 Nisan 2020) (SG/Inf(2020)11).

Birn A, Nikolai Krementsov, 'Socialising' primary care? The Soviet Union, WHO and the 1978 Alma-Ata Conference' (2018) 3(3) BMJ Global Health 1.

Bishop D, 'Lessons from SARS: Why the WHO Must Provide Greater Economic Incentives for Countries to Comply with International Health Regulations' (2005) 36 Geo J Int'l L 1173.

BM Ekonomik ve Sosyal Konsey, 'General Comment 14" 
BM Genel Sekreteri Kofi Annan'ın Basın Açılaması, 'World Health Assembly's Revised Regulations "Bold and Necessary Step" to Protect Global Public Health, Says SecretaryGeneral' (UN, 23 Mayıs 2005) < https://www.un.org/press/en/2005/sgsm9886.doc.htm> Erişim Tarihi 21 Mayis 2020.

BM Güvenlik Konseyi Kararı 1983 (2011).

BM Güvenlik Konseyi Kararı 2177 (2014).

BM Güvenlik Konseyi Kararı 2463 (2019).

BM İnsan Hakları Komitesi, 'Statement on derogations from the Covenant in connection with the COVID-19 pandemic' (24 Nisan 2020) (CCPR/C/128/2).

BM İnsan Hakları Komitesi, 'CCPR General Comment No. 29: Article 4: Derogations during a State of Emergency' (31 Ağustos 2001) (CCPR/C/21/Rev.1/Add.11).

BM İnsan Hakları Yüksek Komiserliği, 'Key concepts on ESCRs - Are economic, social and cultural rights fundamentally different from civil and political rights?' $<$ https://www.ohchr. org/EN/Issues/ESCR/Pages/AreESCRfundamentallydifferentfromcivilandpoliticalrights.aspx> Erişim Tarihi 3 Haziran 2020.

Bown C, Hillman J, 'Bird Flu, the OIE, and National Regulation: The WTO's India-Agricultural Products Dispute' (2016) 15 World Trade Review 235.

Bradley A Thayer, Lianchao Han, 'China and the WHO's chief: Hold them both accountable for pandemic' (The Hill, 17 Mart 2020) <https:/thehill.com/opinion/international/487851-chinaand-the-whos-chief-hold-them-both-accountable-for-pandemic > Erişim Tarihi 28 Mayıs 2020.

Briggs H, 'The Travaux Préparatoires of the Vienna Convention on the Law of Treaties' (1971) 65 American Journal of International Law 705.

Burci G L, 'The World Health Organization at 70: Challenges and Adaptation' (2019) 16(2) International Organizations Law Review 229.

Cases' (Financial Times, 5 Şubat 2020) <https://www.ft.com/content/8ede7e92-4749-1leaaeb3-955839 e06441> Erişim Tarihi 28 Mayıs 2020.

Chris Pleasance, 'How the man running World Health Organisation trashed by Trump as Chinacentric is a career politician who worked for a Communist junta and became WHO's first NONdoctor Director-General 'following intense lobbying from Beijing"' (DailyMail, 8 Nisan 2020) $<$ https://www.dailymail.co.uk/news/article-8199719/Dr-Tedros-Ghebreyesus-career-politicianrunning-China-centric-WHO.html> Erişim Tarihi 28 Mayıs.

Condon B and Sinha T, Global Lessons from the AIDS Pandemic. Economic, Financial, Legal and Political Implications (Springer 2008).

Convention between Austria-Hungary, France, Germany, Portugal and Switzerland Respecting Measures to be Taken Against Phylloxera Vastatrix (1878) (159 CTS 203).

Cueto M, 'The Origins of Primary Health Care and Selective Primary Health Care' (2004) 94 American Journal of Public Health, 1864.

Davies S E, Kamradt-Scott A ve Rushton S, Disease Diplomacy: International Norms and Global Health Security (Johns Hopkins University Press 2015).

Deniz Baran, 'Covid-19 Salgını ve Çin'in Uluslararası Hukuk Açısından Sorumluluğu' (GPoT Center, Nisan 2020) <http://www.gpotcenter.org/sites/default/files/opinion/Covid-19\%20 Salgini\%20ve\%20Cin'in\%20Uluslararasi\%20Hukuk\%20Acisindan\%20Sorumlulugu.pdf> Erişim Tarihi 17 Mayıs 2020.

Doha Deklarasyonu (WT/MIN(01)/DEC/2) (2001) 
DSÖ Genel Direktörü, 'IHR Emergency Committee on Novel Coronavirus (2019-nCoV)',

DSÖ, 'Considerations for quarantine of individuals in the context of containment for coronavirus disease (COVID-19)' (19 Mart 2020).

Dünya Sağlik Örgütü, 'Annual Report on the Implementation of the International Health Regulations, Report by the Director-General' (2019) (A72/8) para 26.

Dünya Sağlık Örgütü, 'Coronavirus Disease (COVID-19) Outbreak' (WHO) <https://www.who. int/emergencies/diseases/novel-coronavirus-2019/events-as-they-happen> Erişim tarihi 15 May1s 2020.

Dünya Sağl1k Örgütü, 'Pandemic Influenza Risk Management. A WHO Guide to inform \& harmonize national \& international pandemic preparedness and response' $(W H O, 2017)<\mathrm{https}$ :// bit.ly/3bdu588> Erişim Tarihi 2 Haziran 2020.

Dünya Sağlık Örgütü, 'Report of the WHO-China Joint Mission on Coronavirus Disease 2019 (COVID-19)' (WHO) <https://www.who.int/docs/default-source/coronaviruse/who-china-jointmission-on-covid-19-final-report.pdf $>$ Erişim Tarihi 15 Mayıs 2020.

Dünya Sağlık Örgütü, 'What is a pandemic?' (WHO, 24 Şubat 2020) <https://www.who.int/csr/ disease/swineflu/frequently_asked_questions/pandemic/en/> Erişim tarihi 15 Mayıs 2020.

Dünya Sağlık Örgütü, Resolution WHA 30.43.

Ekonomik ve Sosyal Konsey (UN, 1946-1948) < https://library.un.org/sites/library.un.org/files/ itp/1430-201404101302204694093_0.pdf> Erişim Tarihi 17 Mayıs 2020.

Ekonomik, Sosyal ve Kültürel Haklar Komitesi, 'General Comment No 14: The Right to the Highest Attainable Standard of Health (Article 12 of the International Covenant on Economic, Social and Cultural Rights)' (Refworld, 11 Ağustos 2000) <https://www.refworld.org/pdfid/4538838d0. pdf $>$ Erişim Tarihi 16 Mayıs 2020.

Emily Rauhala, 'World Health Organization: China not sharing data on coronavirus infections among health-care workers' (Washington Post, 26 Şubat 2020) <https://www.washingtonpost. com/world/asia_pacific/world-health-organization-china-not-sharing-data-on-health-careworker-coronavirus-infections/2020/02/26/28064fda-54e4-11ea-80ce-37a8d4266c09_story. html > Erişim Tarihi 28 Şubat 2020.

Enhorn v Sweden App no 56529/00 (ECtHR 2005) .

Fee E, Brown T, '100 Years of the Pan American Health Organization' (2002) 92(12) American Journal of Public Health 1888.

Fidler D 'To Declare or Not to Declare: the Controversy over Declaring a Public Health Emergency of International Concern for the Ebola Outbreak in the Democratic Republic of the Congo' (2019) 14(2) Asian J Wto \& Int'l Health L \& Pol'y 287.

Fidler D, 'From International Sanitary Conventions to Global Health Security: The New International Health Regulations' (2005) 4 Chinese Journal of International Law 325.

Fidler D, 'Return of the Fourth Horseman: Emerging Infectious Diseases and International Law' (1997) 81 Minn L Rev 771.

Fidler D, 'The Ebola Outbreak and the Future of Global Health Security' (2015) 385 The Lancet 1888.

Fidler D, 'The Future of the World Health Organization: What Role for International Law?' (1998) Articles by Maurer Faculty 1080.

Fidler D, 'The Globalization of Public Health: Emerging Infectious Diseases and International Relations' (1997) 5(1) Indiana Journal of Global Legal Studies 11. 
Fidler D, Gostin L O, 'The New International Health Regulations: An Historic Development for International Law and Public Health' (2006) 34(1) JL Med \& Ethics 85.

Fouad R M, 'The Legal Duty to Cooperate amid COVID-19: A Missed Opportunity?' (EJIL Talk, 22 Nisan 2020) <https://www.ejiltalk.org/the-legal-duty-to-cooperate-amid-covid-19-a-missedopportunity> Erişim Tarihi 28 Mayıs 2020.

Gerry Shih, Emily Rauhala ve Lena H Sun, 'Early missteps and state secrecy in China probably allowed the coronavirus to spread farther and faster' (Washington Post, 1 Şubat 2020) < https://www.washingtonpost.com/world/2020/02/01/early-missteps-state-secrecy-china-likelyallowed-coronavirus-spread-farther-faster/> Erişim Tarihi 28 Şubat 2020.

Goodman N M, International Health Organizations and Their Work (Churchill Livingstone, 1971) .

Gostin L vd, 'Ebola in the Democratic Republic of the Congo: Time to Sound a Global Alert?' (2019) 393 The Lancet 617.

Gostin L vd, 'The Normative Authority of the World Health Organization' (2015) 129(7) Public Health 854 .

Gostin L, 'A Proposal for Framework Convention on Global Health' (2007) 10(4) Journal of International Economic Law 989.

Gostin L, Sridhar D, 'Global Health and the Law' (2014) (370) The New England Journal of Medicine 1732.

Gostin Lawrance, 'World Health Law: Toward a New Conception of Global Health Governance for the 21st Century' (2005) 5 Yale J Health Pol'y L \& Ethics 413.

Hanrieder T, International Organization in Time (OUP 2015).

Helen Davidson, 'First Covid-19 case happened in November, China government records show report' (The Guardian, 13 Mart 2020) <https://www.theguardian.com/world/2020/mar/13/firstcovid-19-case-happened-in-november-china-government-records-show-report> Erişim Tarihi 16 Mayis 2020.

Henry Kissinger, 'The Coronavirus Pandemic Will Forever Alter the World Order' (Wall Street Journal, 3 Nisan 2020) < https://www.wsj.com/articles/the-coronavirus-pandemic-will-foreveralter-the-world-order-11585953005> Erişim Tarihi 29 Nisan 2020.

Heymann D ve Rodier G, 'SARS: A Global Response to an International Threat' (2004) The Brown Journal of World Affairs (2004) 10(2) 185.

Hoen E, 'TRIPS, Pharmaceutical Patents, and Access to Essential Medicines: A Long Way from Seattle to Doha' (2002) 3(1) Chicago Journal of International Law 27.

Hoffman S, 'Making The International Health Regulations Matter: Promoting Compliance Through Effective Dispute Resolution' in Simon Rushton ve Jeremy Youde (eds), Routledge Handbook of Global Health Security (Routledge 2015) .

Huber V, 'The Unification of the Globe by Disease? The International Sanitary Conferences on Cholera, 1851-1894' (2006) 49(2) The Historical Journal 453.

Ian Buruma, 'The Virus of Fear' (Project Syndicate, 6 Mart 2020) <https://www.projectsyndicate.org/commentary/coronavirus-fear-increases-violence-potential-by-ian-buruma-202003?barrier=accesspaylog $>$ Erişim Tarihi 16 Haziran 2020.

Ijaz K vd, 'International Health Regulations - What Gets Measured Gets Done' (2012) 18 Emerging Infectious Diseases 1054.

Ireland v UK App no 5310/71 (ECtHR 1978). 
James Kraska, 'China is Legally Responsible for COVID-19 Damage and Claims Could Be in the Trillions' (War on the Rocks, 23 Mart 2020) <https://warontherocks.com/2020/03/china-islegally-responsible-for-covid-19-damage-and-claims-could-be-in-the-trillions/> Erişim Tarihi 16 Mayis 2020.

Jeremy Page, Betsy McKay, 'The World Health Organization Draws Flak for Coronavirus Response' (Wall Street Journal, 12 Şubat 2020) <https://www.wsj.com/articles/the-worldhealth-organization-draws-flak-for-coronavirus-response- 11581525207> Erişim Tarihi 28 May1s 2020.

Kamradt-Scott A, 'The International Health Regulations (2005) Strengthening Their Effective Implementation and Utilisation' (2019) 16 International Organizations Law Review.

Karackattu J, 'Infectious Diseases and Securitization: WHO's Dilemma' (2011) 9 Biosecurity and Bioterrorism 181.

Kate Kelland, Stephanie Nebehay, 'Caught in Trump-China feud, WHO leader under siege' (The Japan Times, 16 May1s 2020) <https://www.japantimes.co.jp/news/2020/05/16/asia-pacific/usdonald-trump-china-who-tedros-adhanom-ghebreyesus/> Erişim Tarihi 28 Mayıs 2020.

Kathy Gilsinan, 'How China Deceived the WHO' (The Atlantic, 12 Nisan 2020) <https://www. theatlantic.com/politics/archive/2020/04/world-health-organization-blame-pandemiccoronavirus/609820/> Erişim Tarihi 28 Mayıs 2020.

Kennedy D, 'The Move to Institutions' 1987 8(5) Cardozo Law Review 841.

Kofi Annan, 'Problems without Passports' (Foreign Policy, 9 Kasim 2009) < https://foreignpolicy. com/2009/11/09/problems-without-passports/> Erişim Tarihi 28 Mayıs 2020.

Kreuder-Sonnen C, Emergency Powers of International Organizations. Between Normalization and Containment (OUP 2019).

Lashmankin and Others $v$ Russia App no 57818/09 (ECtHR 2017).

Lawless v. Ireland App no App no 332/57 (ECtHR 1961) para 28.

Lawrance G, Global Health Law (Harvard University Press 2014) .

Lebret A, COVID-19 pandemic and derogation to human rights, Journal of Law and the Biosciences, lsaa015.

Lee K, The World Health Organization (Routledge 2009) .

Li Yuan, 'China Silences Critics Over Deadly Virus Outbreak' (New York Times, 22 Ocak 2020) https://www.nytimes.com/2020/01/22/health/virus-corona.html, Erişim Tarihi: 28 Şubat 2020.

Ling L T, 'Global Health in a Turbulence Time: A Commentary' (2020) 15(1) Asian Journal of WTO \& International Health Law and Policy 27.

Lo C, 'The Missing Operational Components of the IHR (2005) from the Experience of Handling the Outbreak of COVID-19: Precaution, Independence, Transparency and Universality' (2020) 15(1) Asian Journal of WTO \& International Health Law and Policy 1.

Mack E, 'The World Health Organization's New International Health Regulations: Incursion on State Sovereignty and Ill-Fated Response to Global Health Issues' (2006-2007) 7 Chinese Journal of International Law 365.

Marko Svicevic, 'COVID-19 as a Threat to International Peace and Security: What place for the UN Security Council?' (EjilTalk, 27 Mart 2020) <ejiltalk.org/covid-19-as-a-threat-to-internationalpeace-and-security-what-place-for-the-un-security- council/> Erişim Tarihi 16 Haziran 2020.

Martin R, The Exercise of Public Health Powers in Cases of Infectious Disease: Human Rights Implications" (2006) 14 Medical Law Review 132. 
Medeni ve Siyasi Haklar Sözleşmesi'nin Sınırlandırma ve Derogasyon Hükümlerine İlişkin Siracusa İlkeleri (UN Doc. E/CN.4/1985/4) (1985).

Mehmet Hasan Altan v. Turkey App no 2016/23672 (ECtHR 2018) para 94, 210.

Morens D, Taubenberger J, 'The Mother of All Pandemics Is 100 Years Old (and Going Strong)!' (2018) 108 American Journal of Public Health 1449.

Natalie Huet, Carmen Paun 'Meet the world's most powerful doctor: Bill Gates' (Politico, 4 Mayıs $2017)<$ https://www.politico.eu/article/bill-gates-who-most-powerful-doctor/> Erişim Tarihi 19 May1s 2020.

Ntina Tzouvala, 'COVID-19, international law and the battle for framing the crisis' (International Law Association Reporter, 25 Mart 2020) <https://bit.ly/33K5tBy> Erişim Tarihi 14 Haziran 2020.

Pavone I, 'Ebola and Securitization of Health: UN Security Council Resolution 2177/2014 and Its Limits' in Leonie Vierck, Pedro A Villarreal ve Katarina Weilert (eds), The Governance of Disease Outbreaks International Health Law: Lessons from the Ebola Crisis and Beyond (Nomos 2017).

Pedro Villarreal, 'The 2019-2020 novel coronavirus outbreak and the importance of good faith for international law' (Voelkerrechtsblog, 28 Ocak 2020) <https://voelkerrechtsblog.org/the-20192020-novel-coronavirus-outbreak-and-the-importance-of-good-faith-for-international-law/> Erişim Tarihi 28 Nisan 2020.

Peel J, Science and Risk Regulation in International Law (CUP 2010).

Phelan A L vd, 'The Novel Coronavirus Originating in Wuhan, China: Challenges for Global Health Governance' (2020) 323(8) Journal of American Medical Association 709.

Primrose Riordan, Sue-Lin Wong, 'WHO Expert Says China Too Slow to Report Coronavirus

Rushton S, 'Global Governance Capacities in Health: WHO and Infectious Diseases' in Adrian Kay and Owain Williams (eds), Global Health Governance: Crisis, Institutions and Political Economy (Palgrave-MacMillan 2009).

Sell C, 'Ebola and Emerging Infectious Diseases in Armed Conflict: Contemporary Challenges in Global Health Security Laws and Policies' (2020) 29 Minn J Int'1 L 187.

Siddharth S Aatreya, 'Are COVID-19 Related Trade Restrictions WTO-Consistent?' (EjilTalk, 25 Nisan 2020) <www.ejiltalk.org/are-covid-19-related-trade-restrictions-wto-consistent> Erişim Tarihi 14 Haziran 2020.

Steinbrück-Platise M, 'The Changing Structure Of Global Health Governance' in Leonie Vierck, Pedro A Villarreal ve Katarina Weilert (eds), The Governance of Disease Outbreaks. International Health Law: Lessons from the Ebola Crisis and Beyond (Nomos 2017) .

Talita de Souza Dias, Antonio Coco, 'Part III: Due Diligence and COVID-19: States' Duties to Prevent and Halt the Coronavirus Outbreak' (EJIL Talk, 25 Mart 2020) < ejiltalk.org/part-iii-duediligence-and-covid-19-states-duties-to-prevent-and-halt-the-coronavirus-outbreak/> Erişim Tarihi 16 May1s 2020.

Taylor A L, 'International Law and Public Health Policy' in Kris Heggenhougen vd (eds) International Encyclopaedia of Public Health (Academic Press 2008) 675

Taylor A L, Bettcher D W, 'International Law and Public Health' (2002) 80(12) Bull World Health Org 923.

Temyiz Organ1 Kararı, 'European Communities - Measures Affecting Asbestos and AsbestosContaining Products' (12 Mart 2001) (WT/DS135/AB/R).

Temyiz Organı Kararı, 'Indonesia - Importation of Horticultural Products, Animals and Animal Product' (9 Kasim 2017) (WT/DS477/AB/R, WT/DS478/AB/R). 
Temyiz Organı Kararı, 'Korea — Various Measures on Beef’ (11 Aralık 2000) (WT/DS161, DS169/AB/R).

Teo Armus, 'Trump threatens to permanently cut WHO funding, leave body if changes aren't made within 30 days' (Washington Post, 19 May1s 2020) <https://www.washingtonpost.com/ nation/2020/05/19/who-funding-trump/> Erişim Tarihi 25 Mayıs 2020.

The White House, 18 May1s $2020<$ https:/www.whitehouse.gov/wp-content/uploads/2020/05/ Tedros-Letter.pdf $>$ Erişim Tarihi 28 Mayıs 2020.

Thomas Bollyky, VinGupta, 'What WorldCanLearnfrom China'sExperiencewithCoronavirus?'(Foreign Affairs, 2 Mart 2020) <https://www.foreignaffairs.com/articles/china/2020-03-02/what-world-canlearn-chinas-experience-coronavirus> Erişim Tarihi 28 Mayıs 2020.

Ulutaş Ufuk, 'Koronavirüs Sonrası Küresel Trendler' in T.C. Dışişleri Bakanlığı Stratejik Araştırmalar Merkezi (ed), COVID-19 Sonrası Küresel Sistem: Eski Sorunlar Yeni Trendler ( SAM Yayınları 2020).

Venedik Komisyonu, 'Opinion on the protection of human rights in emergency situation', CDL$\mathrm{AD}(2006) 015)$ para 13.

Venedik Sağlik Sözleşmesi (1897).

Vidigal G, 'Living Without the Appellate Body: Multilateral, Bilateral and Plurilateral Solutions to the WTO Dispute Settlement Crisis' (2019) 20 Journal of World Investment \& Trade 862.

Villarreal P A, 'Pandemic Declarations of the World Health Organization as an Exercise of International Public Authority: The Possible Legal Answers to Frictions Between Legitimacies' (2016) 7(1) Göttingen Journal of International Law 95.

Villarreal P A, 'Public International Law and Human Health: Bridging Conceptual Gaps Through Governance' (2018) 61 German Yearbook of International Law 45.

von Bogdandy A, Villarreal P A, 'Critical Features of International Authority in Pandemic Response: The WHO in the COVID-19 Crisis, Human Rights and the Changing World Order' (2020) 7(18) Max Planck Institute for Comparative Public Law \& International Law (MPIL) Research Paper 1.

von Bogdandy A, Villarreal P A, 'International Law on Pandemic Response: A First Stocktaking In Light of the Coronavirus Crisis' (2020) 7 Max Planck Institute for Comparative Public Law \& International Law (MPIL) Research Paper 1.

Wenham C, 'Public-health Experts Question Whether the WHO Has Been Too Deferential to China in Its Handling ofthe New Virus'(2017) 372 Phil Transactions Royal Soc B 1.

WHO, 30 Ocak 2020) <https://www.who.int/dg/speeches/detail/who-director-general-s-statementon-ihr-emergency-comnmittee-on-novel-coronavirus-(2019-ncov)> Erişim Tarihi 28 Mayıs 2020.

Wilder-Smith A, Freedman D, 'Isolation, Quarantine, Social Distancing and Community Containment: Pivotal Role For Old-Style Public Health Measures in The Novel Coronavirus (2019-Ncov) Outbreak' (2020) 27 Journal of Travel Medicine 2.

WTO, 'India-Measures Concerning the Importation of Certain Agricultural Products (Report of the Appellate Body)' (4 Haziran 2015) (WT/DS430/AB/R).

Yanzhong Huang, 'The Sars Epidemic And Its Aftermath In China: A Political Perspective' (NCBI) $<$ https://www.ncbi.nlm.nih.gov/books/NBK92479/> Erişim Tarihi 26 Mayıs 2020. Christensen T, Painter M, 'The Politics of SARS - Rational Responses or Ambiguity, Symbols and Chaos?' (2004) 23 Politics and Society 18.

Yuval Noah Harari, 'The World After Coronavirus' (Financial Times, 20 Mart 2020) <https://www. ft.com/content/19d90308-6858-11ea-a3c9-1fe6fedcca75> Erişim Tarihi 29 Mart 2020.

Yüksel C, Uluslararası Hukuk ve Ekonomik Kalkınma (Alfa 2020). 